\title{
Does Herding Behavior Reveal Skill? An Analysis of Mutual fund Performance
}

\author{
HAO JIANG and MICHELA VERARDO*
}

\begin{abstract}
We uncover a negative relation between herding behavior and skill in the mutual fund industry. Our new, dynamic measure of fund-level herding captures the tendency of fund managers to follow the trades of the institutional crowd. We find that herding funds underperform their antiherding peers by over $2 \%$ per year. Differences in skill drive this performance gap: antiherding funds make superior investment decisions even on stocks not heavily traded by institutions, and can anticipate the trades of the crowd; furthermore, the herding-antiherding performance gap is persistent, wider when skill is more valuable, and larger among managers with stronger career concerns.
\end{abstract}

Keywords: Herding, mutual funds, performance, ability, imitation, alpha.

J.E.L. codes: G11, G20, G23.

\footnotetext{
${ }^{*}$ Hao Jiang is at Michigan State University. Michela Verardo is at the London School of Economics. Corresponding author: Michela Verardo (m.verardo@lse.ac.uk). We thank two anonymous referees, an anonymous Associate Editor, and the Editor, Kenneth Singleton, for many insightful comments and suggestions. We are grateful for comments from Amil Dasgupta, Dong Lou, Christopher Polk, Łukasz Pomorski, René Stulz, Sheridan Titman, Dimitri Vayanos, Paul Woolley, and Kathy Yuan, as well as from conference participants at the 2011 IDC Summer Conference, 2012 WFA, and 2015 CFA UK Society and seminar participants at the Universities of Aarhus, Amsterdam, Arizona, BI Oslo, Cattolica Milan, Cologne, Drexel, Erasmus Rotterdam, ESSEC, IESE Barcelona, Kent, London School of Economics, Lugano, Mannheim, Michigan State, Nottingham, Reading, and Vienna. Verardo gratefully acknowledges financial support from the Paul Woolley Centre at the London School of Economics. The authors have no conflicts of interest to disclose.
} 
Theories of herding behavior predict that people tend to "follow the crowd" for a variety of reasons, for instance, to appear as talented as others or to learn from others. ${ }^{1}$ One important yet underexplored feature of these models is the idea that less skilled individuals may herd on the decisions of their predecessors, while those with superior ability may be more likely to deviate from past actions - to the point of exhibiting antiherding behavior. Despite the rich implications of this intuition, however, there is little empirical evidence on the relationship between skill and the tendency to follow the crowd.

In this paper we investigate the link between herding behavior and skill in the context of the mutual fund industry, which is an ideal setting to study the relation between herding and skill for two reasons. First, ample evidence shows that mutual funds and other institutional investors tend to herd in their buying and selling decisions. ${ }^{2}$ Second, an extensive empirical literature on mutual fund performance analyzes the returns and investment decisions of mutual fund managers in an attempt to measure unobservable skill. ${ }^{3}$

To address the question of whether investors can identify skilled and unskilled mutual fund managers by observing their tendency to herd, we create a dynamic measure of fund-level herding that captures the tendency of a fund manager to imitate the trading decisions of the institutional crowd. We then test whether differences in herding behavior across funds predict mutual fund performance and whether skill drives the link between herding and future performance.

In line with the theoretical literature, our measure of fund herding is based on the intertemporal correlation between the trades of a given fund and the collective trading decisions that institutional investors have made in the past. ${ }^{4}$ Each quarter we estimate the relation between a fund's trades and past institutional trades. We then average this relation over previous periods in the life of the fund to obtain a measure of herding tendency. We control for a stock's market capitalization, bookto-market ratio, and past returns to account for potential correlated trading induced by common investing styles. After filtering out these common information components, our measure of herding captures a fund's tendency to imitate the past trading decisions of the crowd.

Our estimates of fund herding reveal a large degree of heterogeneity in herding behavior, with some funds exhibiting a tendency to follow the crowd while others show a propensity to trade in the opposite direction. These differences in fund herding have strong predictive power for the cross-section of mutual fund returns. The top-decile portfolio of herding funds underperforms the bottom-decile portfolio of antiherding funds by $2.28 \%$ on an annualized basis, both before and after 
expenses. We obtain similar results when we account for exposures to factors such as the market risk premium, size, value, momentum, and liquidity: the alphas from different multi-factor models vary between $1.68 \%$ and $2.52 \%$ on an annualized basis. Accounting for time-varying factor exposures yields a predicted performance gap of $2.04 \%$ per year. In multivariate predictive regressions, fund herding can predict four-factor alphas after controlling for fund size, age, turnover, expense ratios, net flows, and past performance. Furthermore, fund herding remains a strong predictor of mutual fund performance when we control for determinants of herding behavior that have been shown to predict mutual fund performance. ${ }^{5}$ Taken together, our results strongly support the view that herding behavior captures unobservable skill.

How do differences in skill lead to differences in herding behavior? Theoretical models of sequential decision-making suggest that differences in ability or information quality can drive differences in herding tendencies. For example, reputational herding models predict that while managers tend to follow their predecessors to enhance the market's perception of their ability, managers with superior ability might choose to antiherd, "going against market trends" (Avery and Chevalier (1999)). Models of sequential information acquisition predict that earlier-informed investors anticipate the actions of later-informed investors and hence can profit by reversing their positions, thus exhibiting antiherding behavior (Hirshleifer, Subrahmanyam, and Titman (1994)). Models of informational cascades predict that while agents tend to disregard their information signals to follow the crowd, higher-precision individuals are more likely to use their information (Bikhchandani, Hirshleifer, and Welch (1992)). ${ }^{6}$

We conduct a number of tests to deepen our understanding of the link between heterogeneity in herding behavior and skill. First, we test whether antiherding funds consistently make better investment decisions than herding funds, irrespective of the decisions of the institutional crowd. Specifically, we analyze the performance of mutual funds' investment choices for the subset of stocks that are not heavily traded by institutions. The results show that stocks that constitute large bets by antiherding funds outperform stocks held mostly by herding funds: the difference in returns is large and significant, with an average Carhart alpha of 38 bps per month. Antiherding funds therefore make better investment decisions than their herding peers, even on stocks that are not subject to potential price pressure caused by institutional herds.

Second, we examine time-series variation in the performance gap between herding and antiherding funds. If differences in skill drive differences in herding behavior, we should observe a widening 
of the performance gap in times of greater investment opportunities in the mutual fund industry, which skilled funds would be better able to exploit. Using stock return dispersion, average idiosyncratic volatility, and investor sentiment to capture time-varying investment opportunities, we find that the performance gap between herding and antiherding funds is indeed significantly larger during and after periods in which opportunities for active managers are more valuable.

Third, we show that the performance gap between herding and antiherding funds is persistent, with return differentials that are large and significant over horizons of up to two years after the measurement of fund herding. This result suggests that the link between herding behavior and future performance is not due to chance.

Fourth, we consider a sequential information acquisition framework in which earlier-informed investors trade ahead of others and subsequently profit by unwinding their positions, thereby exhibiting antiherding behavior (Froot, Scharfstein, and Stein (1992), Hirshleifer, Subrahmanyam, and Titman (1994)). In this setting, earlier-informed investors are able to anticipate the trades of later-informed investors. We show that the trades of antiherding funds can predict the trades of the institutional crowd, suggesting that their outperformance is related to superior ability and informational advantages.

Inspired by the theoretical literature on reputational herding, we next study how skill interacts with career concerns to shape the response of mutual fund managers to reputational incentives. We build on previous work on career concerns in the mutual fund industry (Chevalier and Ellison (1999)) and argue that imitating the crowd can represent a rational response to career concerns. We first show that inexperienced managers face higher probabilities of termination and herding can reduce inexperienced managers' greater likelihood of termination. When we introduce skill in our analysis, we find that, as predicted, the negative relation between herding behavior and future performance is stronger for inexperienced managers. This result suggests that, among careerconcerned managers, a strong herding tendency reveals lack of skill, whereas antiherding might signal superior ability in the absence of a sufficiently long performance record.

We conclude our empirical analysis by conducting a series of tests to assess the robustness of the predictive ability of fund herding for mutual fund performance. We start by showing that our results are not sensitive to the empirical methodology used to estimate fund herding; they continue to hold if we estimate the trade regression after filtering out not only investment styles such as size, value, and momentum, but also a large set of stock characteristics such as liquidity, idiosyncratic volatility, 
net issuance, industry membership, and revisions in analyst earnings forecasts. We also show that the fund flows channel does not drive our findings, as our predictive regressions of performance include a control for fund flows, ${ }^{7}$ and we estimate fund herding after controlling for a fund's own past trades, which accounts for trade persistence induced by persistent capital flows. Finally, we show that our results are not sensitive to how we measure fund performance: in particular, the results continue to hold when we use performance measures based on funds' holdings or trades.

Our analysis brings together and extends two large bodies of empirical work that thus far have evolved separately. First, we contribute to the literature on mutual fund performance, which seeks to address the challenge of identifying skilled managers in the cross-section of mutual funds. Recent studies in this literature construct new measures of skill based on funds' holdings and trades in an attempt to find reliable predictors of mutual fund returns. Our evidence on the predictability of mutual fund performance uncovers the role of herding behavior as a powerful tool to capture the distribution of skill among mutual fund managers.

Second, we contribute to the empirical literature on herding behavior. First, we introduce a dynamic measure of fund-level herding behavior and relate it to managerial skill in the mutual fund industry. Previous studies estimate institutional herding using stock-level measures of the clustering of trades in a given period, with a focus on their impact on stock prices. ${ }^{8}$ In contrast, our measure of fund herding enables us to investigate the dynamic link between imitative behavior and skill while controlling for fund characteristics and filtering out common information signals, common preferences, and common investment styles. Second, we shed new light on the dynamics of herding behavior over a manager's career cycle. Chevalier and Ellison (1999) show that younger mutual fund managers are less likely to make investment decisions that deviate from their peers. We extend this analysis by using our dynamic measure of imitation and analyzing its interaction with managerial ability. We show that differences in herding behavior reveal differences in skill for less experienced managers, who cannot rely on a long performance record to signal their ability. Our results represent an important step toward understanding how incentives shape managerial behavior in the presence of cross-sectional dispersion in skill.

The remainder of this paper is structured as follows. Section I describes the construction of our measure of fund-level herding. Section II presents our main results on the ability of fund herding to predict mutual fund performance. Section III presents tests that identify skill as the driver of the link between fund herding and future performance. Section IV investigates the relation 
between skill and herding in the presence of reputational concerns. Section V provides results of several robustness tests using alternative estimates of fund herding and fund performance. Section VI presents evidence on whether investors respond to the information contained in fund herding. Section VII concludes the paper.

\section{Fund Herding}

In this section we begin by describing the data. We then describe the estimation of our measure of fund herding, namely the tendency of mutual funds to follow past institutional trades.

\section{A. Data}

Our sample consists of all actively managed U.S. equity funds from 1990 to 2009. Data on monthly fund returns and other fund characteristics come from the CRSP Mutual Fund database, and data on fund stock holdings come from the Thomson Reuters Mutual Fund Holdings database. As we wish to capture active mutual funds that invest primarily in U.S. equities, we first exclude index funds from our sample. We then follow Kacperczyk, Sialm, and Zheng (2008) and eliminate balanced, bond, money market, sector, and international funds, as well as funds that do not primarily invest in US common equity. ${ }^{9}$ To address the incubation bias documented by Elton, Gruber, and Blake (2001) and Evans (2010), we further exclude observations prior to the reported fund inception date, and funds whose net assets fall below $\$ 5$ million. We also require that funds have at least 10 stock holdings to be eligible for consideration in our analysis. This process leaves us with 2,255 distinct mutual funds.

To compute aggregate institutional trades, we use data from Thomson Reuters Institutional Holdings database, which collects institutional investors' $13 \mathrm{~F}$ filings. ${ }^{10}$ Finally, we obtain stock price and return data from the CRSP monthly stock files and accounting information from Compustat.

Panel A of Table I reports descriptive statistics for our pooled sample of 56,116 fund-quarters. The characteristics include fund size (total net assets under management, in millions of dollars), fund age (in years), fund turnover, expense ratio, quarterly net flows (computed as the growth rate of assets under management after adjusting for the appreciation of the fund's assets), and quarterly net fund returns. An average fund in our sample manages 1.6 billion dollars of assets, is 17 years old, has an annual expense ratio of $1.27 \%$, and has an annual turnover ratio of $85 \%$. The average 
fund achieves an average net return of $1.55 \%$ per quarter and attracts $1.32 \%$ net money flow. These numbers are in line with those typically reported in the mutual fund literature.

\section{[Insert Table I about here]}

\section{B. Fund Herding Measure}

We define fund herding as the tendency of a mutual fund to imitate past actions of the institutional crowd. Theoretical models of herding behavior analyze the incentives and choices of agents who decide whether to follow the crowd after looking at the decisionspreviously made by other agents (Scharfstein and Stein (1990), Banerjee (1992), Bikhchandani et al. (1992)). This dynamic imitative behavior implies an intertemporal correlation between the action of an agent and the previous actions of the crowd. In line with this idea of sequential decision-making, our measure of herding captures dynamic imitation of past actions. The empirical literature on herding has not sufficiently emphasized the inherently dynamic nature of imitative behavior. The most commonly used measure of institutional herding, introduced by Lakonishok, Shleifer, and Vishny (1992, LSV), is based on the proportion of funds that buy the same stock in the same quarter. However, this measure is not ideal for capturing a fund's tendency to imitate the crowd, for two main reasons. First, it is constructed at the stock level, and thus is a stock characteristic rather than a fund characteristic. Second, it describes the clustering of mutual funds' trades in a given stock at a given point in time rather than a dynamic tendency to follow the decisions of the crowd. ${ }^{11}$

With our new approach, we focus on developing a measure that is more closely related to the theoretical concept of herding. Our measure has two novel characteristics: (i) it is estimated at the fund level, and (ii) it captures the dynamic link between the decisions of a fund and the decisions made by the crowd in the past. To capture the actions of a fund, we use its trades, and to represent the crowd in a comprehensive way, we use the set of all institutional investors. Specifically, for each fund $j$ and quarter $t$, we run a cross-sectional regression of fund trades on past aggregate institutional trades:

$$
\operatorname{Trade}_{i, j, t}=\alpha_{j, t}+\beta_{j, t} \Delta I O_{i, t-1}+\gamma_{1 j, t} \operatorname{Mom}_{i, t-1}+\gamma_{2 j, t} M C_{i, t-1}+\gamma_{3 j, t} B M_{i, t-1}+\varepsilon_{i, j, t} .
$$

The dependent variable is the percentage change in the number of split-adjusted shares of stock $i$ in the portfolio of mutual fund $j$ during quarter $t$ : $\operatorname{Trade}_{i, j, t}=\left(N_{i, j, t}-N_{i, j, t-1}\right) / N_{i, j, t-1} \cdot{ }^{12}$ 
The main independent variable is the change in the aggregate institutional ownership of stock $i$ during quarter $t-1$, where institutional ownership is the fraction of shares outstanding of stock $i$ owned by institutional investors (13F institutions): $\Delta I O_{i, t-1}=N_{i, t-1} / N_{i, t-1}^{\text {out }}-N_{i, t-2} / N_{i, t-2}^{\text {out }}$. The trade regressions control for three stock characteristics representing the main investment styles of mutual funds: momentum, $\operatorname{Mom}_{i, t-1}$, the return on stock $i$ measured during quarter $t-1$; market capitalization, $M C_{i, t-1}$, the natural $\log$ of the market capitalization of stock $i$ at the end of quarter $t-1$; and book-to-market, $B M_{i, t-1}$, the log book-to-market ratio of the stock at the end of the previous quarter. To render the magnitude of the slope coefficients comparable across funds and over time, we standardize both the dependent and the independent variables such that they have a mean of zero and a standard deviation of one for each fund-quarter. ${ }^{13}$

The slope coefficient, $\beta_{j, t}$, captures the association between manager $j$ 's trades in the current quarter and institutional trades in the previous quarter, and forms the building block of our measure of fund herding. The inclusion of stock characteristics in the trade regressions is a novel aspect of our approach to estimating fund-level herding: it allows us to control for commonalities in investment styles and institutional preferences, which could give rise to correlated trades across money managers. We include a stock's past returns to control for the tendency of mutual funds to engage in positive feedback trading (Grinblatt, Titman, and Wermers (1995)). We also include a stock's market capitalization and book-to-market ratio to control for the possibility that a common investment style may induce correlated trading (Barberis and Shleifer (2003), Froot and Teo (2008)). The slope $\beta_{j, t}$ can therefore be interpreted as a partial correlation coefficient between current fund trades and past aggregate trades, which captures imitation and is not confounded by common preferences or other determinants of comovement in trading decisions.

We next construct our measure of fund-level herding, $F H_{j, t}$, which captures the average tendency of a fund to follow past institutional trades. In particular, we adopt a rank inverse-weighting scheme that assigns higher weights to more recent observations. For each fund $j$ and quarter $t$, we compute the weighted average of $\beta_{j, t}$ during the fund's history up to quarter $t$, with weights that vary inversely with the distance of the coefficients from quarter $t$ :

$$
F H_{j, t}=\frac{\sum_{h=1}^{t} \frac{1}{h} \beta_{j, t-h+1}}{\sum_{h=1}^{t} \frac{1}{h}} .
$$


By attributing higher weights to more recent coefficients, this measure reflects more strongly the fund's most recent trading decisions. A mutual fund investor who observes the history of fund $j$ 's trades would plausibly want to use as much information as possible to estimate the fund's average tendency to herd, while updating his estimate with fresh information each quarter. Attributing more weight to more recent information allows the investor to account for changes in the fund's trading behavior and for the decay of the information content of fund trades over time. ${ }^{14}$

Panel B of Table I presents descriptive statistics for the coefficients $\beta_{j, t}$ and the fund herding measure $F H_{j, t}$. The statistics include mean, standard deviation, and several quantiles computed cross-sectionally each quarter and then averaged over the 80 quarters in our sample. The results show that on average betas are equal to $2.30 \%$, with a standard deviation of $18.73 \%$. Fund herding has a similar mean, at $2.42 \%$, and considerably lower standard deviation, at $7.12 \% .{ }^{15}$ Most importantly, these results show that fund herding exhibits substantial heterogeneity, varying from $-8.81 \%$ (5th percentile) to $13.86 \%$ (95th percentile). It is precisely this cross-sectional heterogeneity that is the focus of our analysis on fund herding, performance, and skill.

\section{Fund Herding and Future Performance}

To investigate the link between herding behavior and skill, we start by testing whether fund herding has predictive power for the cross-section of mutual fund performance. We examine both net returns and gross returns, which add back fees and expenses. We start from univariate portfolio tests. We then estimate predictive regressions that control for multiple fund characteristics.

\section{A. Portfolios}

In this subsection we use portfolio-based analysis to examine the link between fund herding and future performance. At the end of each quarter, we sort mutual funds into 10 portfolios based on our measure of fund herding, $F H_{j, t}$. We then compute equally weighted returns for each decile over the subsequent quarter, both net and before fees and expenses. We also estimate the risk-adjusted returns of these portfolios as intercepts from time-series regressions using the capital asset pricing model (CAPM), the three-factor model of Fama and French (1993), the four-factor model of Carhart (1997), and the five-factor model of Pástor and Stambaugh (2003). To allow for time-variation in factor loadings, we follow Ferson and Schadt (1996) and assume a linear 
relation between factor loadings and five conditioning variables: a January dummy and four lagged macroeconomic variables, namely, the one-month Treasury bill yield, the aggregate dividend yield, the term spread, and the default spread.

Table II presents the portfolio results. The top row reports the average value of fund herding for each decile portfolio, measured at the end of quarter $t$. Funds in the top decile exhibit a strong tendency to follow past institutional trades, with mean values of fund herding reaching $15.3 \%$, whereas funds in the bottom decile exhibit antiherding behavior, with large and negative values of fund herding reaching $-10.4 \%$. Fund returns are measured in each month of quarter $t+1$. The panel for net returns shows that, in the quarter following portfolio formation, the funds with the highest herding tendency in decile 10 underperform the funds with the highest antiherding tendency in decile 1 by 19 bps per month, which implies a return differential of $2.28 \%$ per year. The performance differential between herding and antiherding funds cannot be attributed to differences in risk loadings or investment styles, as the differences in alphas from the CAPM, Fama and French, Carhart, Pástor and Stambaugh, and Ferson and Schadt models are $-21,-17,-16,-14$, and -17 bps per month, all statistically significant. If we consider gross fund returns, the results paint the same picture: herding funds in decile 10 strongly underperform their antiherding peers in decile 1. Overall, the performance differential between herding and antiherding funds ranges between $1.68 \%$ and $2.52 \%$ on an annualized basis.

The results above show that cross-sectional differences in fund herding can significantly predict differences in mutual fund performance, which suggests that fund herding is related to mutual fund skill. The performance differential between herding and antiherding funds is economically

important, especially when considered in light of existing evidence on cross-sectional dispersion in mutual fund performance.

\section{[Insert Table II about here]}

\section{B. Determinants of Fund Herding}

In this subsection we investigate the relation between fund herding and several fund characteristics previously shown to be associated with fund performance. Table III reports the results. The first column presents coefficient estimates from a cross-sectional regression of fund herding on fund size, age, expense ratio, turnover, net flows, and performance (measured by a fund's Fama- 
French alpha estimated over the previous three years). The results show that funds with a stronger propensity to herd tend to be older and less active, as indicated by the lower portfolio turnover. Other fund characteristics such as expense ratios and past performance do not play a significant role in explaining cross-sectional differences in mutual fund herding.

\section{[Insert Table III about here]}

We also consider recently developed measures of mutual fund skill that might be viewed as naturally linked to our measure of fund herding; since these measures have been previously used to predict fund returns, we include them as controls in our analysis of fund herding and performance. First, herding funds might underperform their peers if they do not deviate from their benchmarks; Cremers and Petajisto (2009) show that funds with lower active share, that is, whose portfolios overlap more with their benchmark, tend to underperform. Second, they might underperform if they rely more on public information, as shown by Kacperczyk and Seru (2007). Third, they might underperform if their investment decisions differ from those of funds with good past performance, as documented by Cohen, Coval, and Pástor (2005). ${ }^{16}$

The second column of Table III shows that fund herding is related to these three measures in intuitive ways: funds with a higher tendency to herd exhibit lower active share, stronger reliance on public information, and weaker similarity with the investment decisions of successful funds. As an alternative measure of the degree to which a fund deviates from its benchmark, in the third column of the table we use tracking error. The results show a negative relation between fund herding and tracking error, which provides further evidence that antiherding funds exhibit a relatively higher

tendency to deviate from benchmarks. In summary, the evidence in this section suggests that less skilled and less active funds appear to herd more.

\section{Predictive Regressions}

Given the association between fund herding and fund characteristics documented in the previous subsection, we now use multivariate regressions to examine the robustness of the predictive power of herding for mutual fund performance. Our measure of performance is the monthly four-factor alpha of Carhart (1997), estimated over the months in quarter $t+1$ as the difference between the realized fund return in excess of the risk-free rate and the expected excess fund return from a fourfactor model that includes the market, size, value, and momentum factors. The factor loadings are 
estimated from rolling-window time-series regressions of fund returns over the previous three years. Herding and fund characteristics are measured using information available at the end of quarter $t$.

Table IV presents the predictive panel regression results. We first control for fund size, age, portfolio turnover, expense ratio, net flows, and past alpha. We then include controls for the measures described in the previous subsection that are related to fund herding: active share, reliance on public information, similarity with past winners, and tracking error. We measure fund performance using both net and gross fund returns. To control for aggregate movements in fund returns over time, we include time fixed effects in the regressions. Furthermore, since the residuals might correlate within funds, we cluster the standard errors by fund. ${ }^{17}$

We find that fund herding reliably predicts mutual fund performance. The first column of Table IV shows that a univariate regression of four-factor net alphas on past herding yields a slope coefficient of -0.466 , with a $t$-statistic of -5.16 . To provide intuition on the economic magnitude of this coefficient, we note that a fund with a herding tendency of 1.65 standard deviations above average underperforms a fund with a herding tendency of 1.65 standard deviations below average by 11 bps per month, or $1.32 \%$ per year. ${ }^{18}$ Controlling for the influence of fund characteristics (second column) reduces the slope coefficient only slightly to -0.438 , with a $t$-statistic of -4.83 . Inclusion of other measures of skill or other measures of deviation from benchmarks, such as active share, reliance on public information, similarity with successful funds, or tracking error, does not reduce the ability of fund herding to predict mutual fund performance. Furthermore, the results do not change if we measure alphas using gross returns.

\section{[Insert Table IV about here]}

In general, the fund characteristics relate to future fund performance in a way that is consistent with previous findings. For example, consistent with Chen et al. (2004), fund size is negatively related to future performance. Consistent with Carhart (1997), fund turnover is negatively related to future performance. Past flows have a positive relation with future performance, consistent with the smart-money effect documented by Gruber (1996) and Zheng (1999), although their significance is not robust to the introduction of further controls for skill. Expense ratios are unrelated to future gross performance, but negatively predict future net alphas, which deduct fees and expenses. Past alphas are not significantly related to future performance. Finally, active share and similarity with past winners significantly predict mutual fund performance. 
We conclude that cross-sectional differences in fund herding provide investors with valuable information on the distribution of mutual fund skill. Even after controlling for characteristics related to both fund herding and fund performance, fund herding retains its economic importance and statistical significance.

\section{Does Herding Behavior Reveal Skill?}

The predictive power of fund herding for mutual fund performance suggests that herding behavior reveals unobservable skill. In this section we deepen our analysis of the link between herding behavior and managerial skill. We organize our investigation into four parts.

First, we test whether antiherding funds consistently make better investment decisions than herding funds, even when considering stocks that are not heavily traded by the institutional crowd, thus revealing that they are generally more skilled. Second, we test whether the performance gap between herding and antiherding funds widens in times of greater investment opportunities in the mutual fund industry, when managerial ability is more valuable. Third, we test whether this performance gap is persistent over longer horizons, to further check that it is due to differences in skill rather than chance. Finally, we test whether antiherding funds might be able to acquire information earlier than others and exploit their informational advantage by exhibiting antiherding behavior and superior performance.

\section{A. Revealing Skill through Investment Choices}

Differences in skill across funds should be reflected in different investment choices. If the performance gap between herding and antiherding funds is driven by skill, antiherding funds should consistently make better investment decisions than those of their herding peers. We test this hypothesis by analyzing the future returns of the stocks held in the portfolios of funds characterized by different herding tendencies. We focus on the subset of stocks with small changes in institutional ownership, as these stocks are least likely to drive our estimates of fund herding. This stock-level analysis has the advantage of providing a clean identification of the link between herding and skill by excluding potential alternative channels related to price pressure or chance.

This test is designed as follows. Each quarter $t$, we sort all stocks on the absolute value of their prior-quarter change in institutional ownership and select those in the bottom tercile of the 
distribution. We then aggregate the positions of all funds that own these stocks, accounting for each fund's herding tendency. Specifically, we scale the weight of stock $i$ in the portfolio of fund $j\left(w_{i, t}^{j}\right)$ using a simple transformation of our fund herding measure: we demean the herding decile rank of each fund, $\operatorname{rank}\left(F H_{t}^{j}\right)$, flip its sign, and divide by 10. This simple rescaling implies that stocks in the portfolio of herding funds get a negative weight and stocks in the portfolio of antiherding funds get a positive weight. Moreover, the weight of each stock reflects the strength of the herding tendency of the funds that own it. We thus obtain a stock-level measure of fund herding:

$$
S_{i, t}^{F H}=\sum_{j=1}^{J} w_{i, t}^{j}\left(-\frac{\operatorname{rank}\left(F H_{t}^{j}\right)-\overline{\operatorname{rank}\left(F H_{t}^{j}\right)}}{10}\right) .
$$

We test whether this stock-level measure of fund herding predicts stock returns. At the end of each quarter we sort stocks into quintiles based on $S_{i, t}^{F H}$ and compute their monthly returns in the subsequent quarter. If heterogeneity in the propensity to herd captures differences in stock-picking ability across funds, $S_{i, t}^{F H}$ should predict cross-sectional differences in stock returns. In particular, if antiherding funds are more skilled than their herding peers, then stocks with higher $S_{i, t}^{F H}$, which are mostly held by antiherding funds, should outperform those with lower $S_{i, t}^{F H}$, which are mostly held by herding funds.

Table V reports average monthly returns for the five portfolios of stocks sorted on $S_{i, t}^{F H}$, as well as alphas estimated using different performance evaluation models. The results strongly indicate that stocks that represent large bets by antiherding funds outperform stocks that are mostly held by herding funds. The differences in returns are large and significant, irrespective of the model used to estimate alphas; focusing on Carhart alphas, for example, the return gap is on average 38 bps per month. Importantly, this analysis is restricted to stocks that, by construction, are not likely to drive our fund herding estimates. This implies that the performance differential between herding and antiherding funds is not likely to be driven solely by herding and antiherding trades, but rather by investment decisions related to unobservable skill. Moreover, this implies that the return differentials reported in Table $\mathrm{V}$ are attributable to differences in the ability of managers to pick stocks, rather than to potential price pressure induced by changes in institutional ownership. ${ }^{19}$

\section{[Insert Table V about here]}




\section{B. Time-Varying Opportunities and the Value of Skill}

To the extent that the performance gap between herding and antiherding funds is driven by differences in skill, it should increase in times of greater investment opportunities in the mutual fund industry, when investment skill is more valuable. We test this hypothesis using three measures of investment opportunities in the mutual fund industry. First, we consider the crosssectional dispersion in stock returns used by Ankrim and Ding (2002), Petajisto (2013), and Pástor, Stambaugh, and Taylor (2017). As in previous literature, we measure return dispersion using the Russell-Parametric Cross-Sectional Volatility Index for U.S. equities, which is given by

CrossVol $_{t}=\sqrt{\sum_{i=1}^{N} w_{i, t-1}\left(R_{i, t}-R_{m, t}\right)^{2}}$, where $R_{i, t}$ is the return on stock $i$ in month $t, R_{m, t}$ is the return on the market portfolio in month $t$, and $w_{i, t-1}$ is the beginning-of-period, float-adjusted capitalization weight of stock $i{ }^{20}$ As the cross-sectional dispersion in stock returns around the market increases, both the potential gain from outperforming the market and the potential loss from underperforming it increase, and hence the spread in performance between skilled and unskilled managers is likely to widen. The second measure of time-varying profit opportunities for mutual funds is average idiosyncratic volatility $(I V)$, which is computed as the cross-sectional mean of the residual standard deviation from daily Fama-French regressions estimated for each firm-month. The third measure is the investor sentiment index (Sent), which is constructed as in Baker and Wurgler (2006).

We present two sets of results. First, we estimate time-series regressions of the monthly return differential between herding and antiherding funds (decile portfolios 10 and 1, before and after fees) on return dispersion, idiosyncratic volatility, and investor sentiment. The results are reported in Panel A of Table VI. The negative and statistically significant coefficients indicate that the difference in performance between herding and antiherding funds widens both during and after periods of high investment opportunities for active mutual funds, in line with our conjecture.

\section{[Insert Table VI about here]}

We next use our panel regression framework to test whether the cross-sectional differences in performance predicted by fund herding are linked to variation in profit opportunities. Our main independent variables are fund herding and its interaction with return dispersion, idiosyncratic volatility, and investor sentiment. We also control for fund size, age, expense ratio, turnover, flows, and past alpha. The results are reported in Panel B of Table VI. The coefficient estimates on 
fund herding are negative and significant, and of similar magnitude to our baseline results. The estimated coefficients on the interaction terms are significantly negative, particularly for return dispersion and investor sentiment, which suggests that the performance gap between herding and antiherding funds is greater during and after periods of high investment opportunities in the mutual fund industry.

Our analysis of the time-varying performance of herding funds complements recent work by Kacperczyk, Van Nieuwerburgh, and Velkamp (2014, 2016), who focus on fund managers' cognitive ability in processing information and propose a measure of managerial skill that emphasizes market timing in recessions and stock picking in booms. Our results suggest that the tendency of mutual funds to follow the crowd is particularly effective at capturing managerial skill during and after periods in which profit opportunities and firm-specific information are more valuable.

\section{Performance Persistence}

The literature on mutual fund performance has long recognized the challenge in separating mutual fund skill from chance. One may thus wonder if herding funds underperform due to bad luck, while antiherding funds are simply be lucky. To test this potential alternative explanation, we examine the persistence in the performance differential between herding and antiherding funds. Each quarter we group funds into decile portfolios on the basis of their herding tendency and track their performance over the subsequent two years. If the performance gap between herding and antiherding funds were random, we would expect it to weaken and revert to zero as we extend the holding horizon, while if performance is related to skill, we would expect a certain degree of persistence.

The results of this analysis, presented in Table VII, reveal that the performance gap related to herding is remarkably persistent. For example, net and gross return differentials are 15 bps per month in the subsequent six months and persist when we extend the holding period to nine months and 12 months. Similarly, the difference in four-factor alphas between herding and antiherding funds is 11 bps and persists to a horizon of one year. At longer horizons the performance gap starts to taper off, but remains economically important and statistically significant. This high degree of persistence lends further support to the hypothesis that the association between fund herding and future performance is related to skill. 


\section{[Insert Table VII about here]}

\section{Anticipating the Actions of the Crowd}

In this subsection we consider a gradual information acquisition framework to study differences in skill between herding and antiherding funds. In this setting, investors who acquire information earlier than others are more likely to display antiherding behavior. In particular, these earlierinformed investors are likely to exploit their informational advantage by trading ahead of others, and then unwinding their positions when the trades of the later-informed investors cause prices to more fully reflect information, thus realizing a profit (Froot, Scharfstein, and Stein (1992), Hirshleifer, Subrahmanyam, and Titman (1994)). An immediate implication of this theoretical framework is that the earlier-informed investors are able to anticipate the trades of the later-informed investors. We use this implication to test whether the trades of antiherding funds can anticipate the trades of other institutions, thus identifying antiherding funds as the skilled, earlier-informed investors in this economic setting.

Using Fama-MacBeth (1973) cross-sectional regressions, we estimate the ability of herding and antiherding funds to anticipate the trades of the crowd in the subsequent quarter $\left(\Delta I O_{t+1}\right)$ and in the subsequent year $\left(\Delta I O_{t+1: t+4}\right)$. Table VIII presents the results. The estimates show that antiherding funds can significantly predict aggregate institutional trades; the coefficients on the current trades of antiherding funds are positive and statistically significant in all regression specifications. In contrast, the trades of herding funds are not related to subsequent institutional trades. When we include several stock characteristics in the regression specification, we find that past aggregate trades, market capitalization, and stock turnover have negative predictability for aggregate trades, while the trading decisions of antiherding funds retain their positive and significant predictive power. These results provide further evidence of a skill channel that might link differences in herding behavior to differences in mutual fund performance.

[Insert Table VIII about here]

\section{Skill and Reputational Herding}

Theoretical models of reputational herding generally predict that managers have an incentive to imitate the actions of their predecessors to enhance the market's perception of their ability. 
Under some conditions, however, managers with superior ability have weaker incentives to herd, choosing instead to deviate from past actions. For example, Scharfstein and Stein (1990) emphasize that factors such as relative performance ranking or the reward for new investment ideas could encourage skilled managers to anti-herd. Moreover, a number of reputational herding models focus on the evolution of career concerns and herding incentives over a manager's career cycle, and derive implications for herding and antiherding behavior conditional on managerial experience. ${ }^{21}$ In this line of research, Avery and Chevalier (1999) develop a model in which experienced managers who are aware of their superior ability choose to anti-herd, "demonstrating their self-confidence by going against market trends." In a different setting, Prendergast and Stole (1996) show that agents who know their expertise may take bold actions to signal that they are talented. ${ }^{22}$

In this section we study how skill interacts with career concerns to shape herding and antiherding incentives. We focus on three questions. First, building on Chevalier and Ellison (1999), we ask whether there is evidence of career concerns among the mutual fund managers in our sample, and whether herding might provide an incentive to attenuate such concerns. Second, we test whether managers with stronger career concerns respond to these potential incentives to herd. Finally, we study the degree to which herding and antiherding choices reveal skill for managers experiencing different levels of career concerns.

Chevalier and Ellison (1999) examine a sample of mutual fund managers over the period 1992 to 1994. Measuring managers' experience with age, and measuring herding behavior using deviations from their peers' investment decisions in a given period, the authors find that younger managers are more likely to be fired for deviating from their peers and are more likely to cluster with their peers' investment decisions. We extend this analysis using our dynamic measure of fund herding. To translate our investigation at the manager level, we restrict our sample to the subset of mutual funds that are managed by an individual manager, excluding team-managed funds. This filter leaves us with about $40 \%$ of the original sample. We construct two measures of managerial experience: (i) general experience, defined as the number of years during which a manager appears on the CRSP database, and (ii) fund-specific tenure, defined as the number of years during which a manager is employed in a given fund.

We start by estimating the determinants of the probability of termination for a fund manager. We measure terminations by keeping track of all instances in which managers lose their position with a fund and disappear from our sample. ${ }^{23}$ We estimate logit regressions in which the dependent 
variable is an indicator for whether the manager of a given fund in quarter $t$ is no longer in our sample from quarter $t+1$ onward. Table IX, Panel A, reports both the estimated logit coefficients and the marginal effects associated with an infinitesimal increase in the variable of interest when all other variables are held at their mean values. The results show that less experienced managers face a higher probability of termination: the coefficient estimates on both general experience and fund-specific tenure are significantly negative. The coefficient on fund herding is negative and significant, indicating that managers have incentives to follow the crowd in order to decrease the probability of negative career outcomes. The results also show that high past performance decreases the probability of termination, fund size and fund age are significant, and tracking error has a marginally significant effect. To gain a more intuitive understanding of the magnitude of the impact of herding behavior, we compute the predicted probability of termination for two managers who belong to the top and bottom deciles of the distribution of fund herding. We calculate that, holding all other variables at their mean values, an antiherding manager faces a $5.5 \%$ probability of termination, whereas a herding manager faces a lower probability of termination of $4.2 \%$. To the extent that following the crowd helps reduce the probability of termination, we can infer that reputational incentives contribute to herding behavior.

In Panel B of Table IX we analyze the impact of herding on termination probabilities conditional on experience (above and below cross-sectional median values). The results show that the impact of herding is large among low-experience managers, whereas it is insignificant for high-experience managers. We find that, among low-experience managers, the probability of termination is $7.4 \%$ for antiherding managers and $5.1 \%$ for herding managers; in contrast, these probabilities are very similar (4.4\% and $4 \%$ ) among experienced managers. Similarly, the benefit of herding translates into a $2.1 \%$ lower probability of termination among managers with shorter fund-specific tenure, but a $0.8 \%$ lower probability of termination for managers with longer tenure. Our evidence on termination probabilities indicates that herding behavior might constitute a rational response to reputational incentives that vary over a manager's career.

\section{[Insert Table IX about here]}

Do mutual fund managers respond to such reputational incentives? We estimate cross-sectional regressions of fund herding on managerial experience, controlling for fund characteristics. The results in Table $\mathrm{X}$ show that less experienced managers are more likely to herd; the negative 
association between experience and herding holds both for general experience and for fund-specific tenure. These results are consistent with Chevalier and Ellison (1999) and, like their study, support models of reputational herding that predict stronger herding incentives for more career-concerned managers. We contribute to their investigation by analyzing this question in a richer framework, using a measure of herding that is dynamic and thus better able to capture the idea of intertemporal imitation.

\section{[Insert Table X about here]}

Finally, we take our investigation further by analyzing differences in performance across managers that differ in the intensity of both their career concerns and their herding tendency. At the end of each quarter, we sort all mutual fund managers into four groups based on fund herding; we also sort them independently into managers with low, medium, and high levels of experience. For each group we compute subsequent net returns and four-factor alphas. The results are presented in Table XI. We find that differences in herding behavior predict large and significant differences in performance for funds with less experienced managers. In particular, using our proxy for general experience, the performance gap between herding and antiherding funds is -18 bps per month for inexperienced managers and becomes insignificant for the most experienced managers. Using our measure of fund-specific tenure, the performance differential associated with differences in herding behavior is $-22 \mathrm{bps}$ for inexperienced managers, decreases to $-16 \mathrm{bps}$ for managers with a medium level of experience, and becomes zero for the most established managers.

These results show that differences in herding behavior reveal skill more strongly for inexperienced, career-concerned managers. Among these managers, a strong herding tendency reveals lack of skill, whereas antiherding behavior offers an opportunity to signal high ability in the absence of a sufficiently long track record. Prior literature documents a link between herding behavior and career concerns. Our investigation adds a new perspective by emphasizing the role of skill as a driver of heterogeneity in herding behavior in the presence of reputational incentives.

\section{[Insert Table XI about here]}




\section{Robustness Tests}

In this section we perform two sets of robustness tests on the ability of fund herding to predict mutual fund performance. First, we estimate fund herding from trade regressions that control for a large number of firm characteristics that may affect the trading decisions of money managers. We also control for potential serial dependence in a fund's own trades. Second, we test the robustness of the association between herding behavior and performance using two alternative measures of mutual fund performance. ${ }^{24}$

\section{A. Alternative Measures of Fund Herding}

\section{A.1. Controlling for Multiple Stock Characteristics}

In the trade regressions used to estimate fund herding, we control for three main variables that describe investment style: momentum, market capitalization, and book-to-market. Here we consider additional stock characteristics that might influence money managers' trading decisions: stock turnover, idiosyncratic volatility, revisions in analyst earnings forecasts, firm share issuance, bid-ask spread, Amihud illiquidity, and 10 industry dummies. We include stock turnover and other liquidity measures because institutions exhibit a preference for liquid stocks, as documented in Gompers and Metrick (2001), which would induce a mechanical correlation between a fund's trades and past institutional trades. Similarly, idiosyncratic volatility (Bennett, Sias, and Starks (2003)), revisions in analyst earnings forecasts (Kacperczyk and Seru (2007)), and past share issuance (Jiang (2010)) could play a role in generating a correlation between the trades of a given fund and past institutional trades. Finally, we include industry controls because prior research presents evidence of industry herding (Choi and Sias (2009)) and documents a link between mutual fund performance and the industry concentration of mutual fund portfolios (Kacperczyk, Sialm, and Zheng (2005)). Since these stock characteristics have been shown to predict returns, they may affect future fund

performance. ${ }^{25}$ We orthogonalize aggregate institutional trades with respect to these characteristics by estimating the following cross-sectional regression in each quarter $t$ for all of the stocks in our 
sample:

$$
\begin{aligned}
\Delta I O_{i, t}= & \gamma_{0 t}+\gamma_{1 t} \text { Mom }_{i, t}+\gamma_{2 t} \text { MC }_{i, t}+\gamma_{3 t} \text { BM }_{i, t}+\gamma_{4 t} \text { Turn }_{i, t}+\gamma_{5 t} \text { IVol }_{i, t}+\gamma_{6 t} \text { FRev }_{i, t}+ \\
& +\gamma_{7 t} \text { Issue }_{i, t}+\gamma_{8 t} \text { Spread }_{i, t}+\gamma_{9 t} \text { Amihud }_{i, t}+\sum_{k=1}^{9} \gamma_{9+k, t} I N D_{i, t}^{k}+\varepsilon_{i, t},
\end{aligned}
$$

where Turn $_{i, t}$ is the number of shares traded for stock $i$ in quarter $t$ scaled by shares outstanding; $I V \mathrm{Vol}_{i, t}$ is the residual standard deviation from a regression of the daily excess returns of stock $i$ on the Fama and French three factors in quarter $t$; $F R e v_{i, t}$ is the change in consensus analyst earnings forecasts scaled by stock price at the end of the previous period; Issue $e_{i, t}$ is the share issuance for firm $i$ in the previous year (the natural log of the split-adjusted shares outstanding at the end of quarter $t$ divided by the split-adjusted shares outstanding at the end of quarter $t-4) ;$ Spread $_{i, t}$ is the end-of-day quoted bid-ask spread scaled by the midquote, averaged over a quarter; Amihud $d_{i, t}$ is the Amihud (2002) daily illiquidity measure, averaged over a quarter; and $I N D_{i, t}^{k}$ is a dummy variable indicating industry membership based on the Fama and French 10-industry classification.

We next estimate cross-sectional regressions of fund trades on past residual institutional trades, by fund and by quarter, and average these quarterly coefficients over the life of a fund to obtain a new measure of fund herding. Based on this new measure, we rank funds into decile portfolios and estimate their performance in the following quarter. The results, presented in Table XII, are very similar to those of our baseline case. For example, the return gap between herding and antiherding funds is now $-16 \mathrm{bps}$ per month $(-19 \mathrm{bps}$ in the baseline case); when measured by Carhart alphas, the performance gap is now -15 bps per month ( $-16 \mathrm{bps}$ in the baseline case). We conclude that the predictive power of fund herding is robust to different ways of estimating the tendency of a mutual fund to follow past institutional trades.

\section{[Insert Table XII about here]}

\section{B.2. Controlling for Past Own Trades}

Persistent fund flows and stealth trading could potentially affect our fund herding measure by generating autocorrelated fund trades, and could affect performance through price pressure and subsequent reversals. ${ }^{26}$ To control for this possibility, and to ensure that fund herding captures imitation in sequential trading decisions, we reestimate our baseline fund trade regressions while 
controlling for funds' own past trades in a given stock, Trade $_{i, j, t-1}$ :

$$
\begin{aligned}
\text { Trade }_{i, j, t}= & \alpha_{j, t}+\beta_{j, t} \Delta I O_{i, t-1}+\gamma_{1 j, t} \operatorname{Mom}_{i, t-1}+\gamma_{2 j, t} M C_{i, t-1}+\gamma_{3 j, t} B M_{i, t-1}+ \\
& +\gamma_{4 j, t} \operatorname{Trade}_{i, j, t-1}+\varepsilon_{i, j, t} .
\end{aligned}
$$

As with our baseline regression, we use the estimates of $\beta_{j, t}$ to compute fund herding, the average tendency to herd for each fund in each quarter, and test whether it predicts performance. The results, presented in Table XIII, confirm the strong negative relation between fund herding and future performance. The return differential between herding and antiherding funds is $-17 \mathrm{bps}$ per month (net or gross), and the four-factor alpha differential is -14bps per month. We conclude that our results are robust to controlling for the correlation in a fund's own trades over time.

\section{[Insert Table XIII about here]}

\section{B. Alternative Measures of Mutual Fund Performance}

The measures of mutual fund performance used in our empirical analysis are based on fund returns, both before and after fees and expenses. In this subsection we reestimate the baseline predictive panel regressions of Table IV using three alternative measures of performance, which are based on mutual funds' stock holdings and trades. We find supportive evidence for a negative and significant relation between fund herding and future performance. The results are presented in Table XIV.

Our first alternative measure of performance is the holdings-based Characteristic-Selectivity measure (CS) developed by Daniel et al. (1997):

$$
C S_{t+1}=\sum_{i=1}^{N} w_{i, t}\left(R_{i, t+1}-R_{i, t+1}^{b}\right)
$$

where $w_{i, t}$ is the weight of stock $i$ in the portfolio of a fund at the end of quarter $t ; R_{i, t+1}$ is the

monthly return of stock $i$ during quarter $t+1$; and $R_{i, t+1}^{b}$ is the corresponding monthly return on the characteristic-based benchmark portfolio for stock $i$. The benchmark portfolios are formed on the basis of size, industry-adjusted book-to-market, and momentum. The first two columns of Table XIV present the estimated coefficients from predictive panel regressions of fund performance on fund herding and other fund characteristics measured in the previous quarter. The results show 
that herding funds exhibit inferior stock-picking ability than their antiherding peers, suggesting that they are less skilled.

As a second alternative measure of performance, we use the trade-based measure of Grinblatt and Titman (1993, GT):

$$
G T_{t+1}=\sum_{i=1}^{N}\left(w_{i, t}-w_{i, t-4}\right) R_{i, t+1}
$$

where $w_{i, t}$ and $w_{i, t-4}$ are the weights of stock $i$ in the fund's portfolio at the end of quarters $t$ and $t-4$; and $R_{i, t+1}$ is the monthly return of stock $i$ during quarter $t+1$. This measure reflects the covariance between the change in the portfolio weights of a stock and its subsequent return. Following Grinblatt and Titman (1993), we compute the change in weights over the year that precedes the measurement of returns. Columns (3) and (4) of Table XIV show that fund herding negatively predicts performance as captured by the GT measure.

\section{[Insert Table XIV about here]}

Finally, we compute the GT measure with respect to the future trades of a fund. We ask whether the trading decisions that mutual funds make after we measure their herding behavior yield different returns for herding and antiherding funds. Specifically, we consider a fund's trades over the year that follows the measurement of fund herding (quarters $t+1$ to $t+4$ ) and compute the monthly returns to these trades in the subsequent quarter, $t+5$ :

$$
G T_{t+5}=\sum_{i=1}^{N}\left(w_{i, t+4}-w_{i, t}\right) R_{i, t+5}
$$

where $w_{i, t+4}$ and $w_{i, t}$ are the weights of stock $i$ in the fund's portfolio at the end of quarters $t+4$ and $t$, and $R_{i, t+5}$ is the monthly return of stock $i$ during quarter $t+5$. The last two columns of Table XIV show that fund herding predicts the returns derived from the trading decisions that funds make over the subsequent year. In particular, herding funds tend to make trading decisions that result in future inferior returns, whereas the trading decisions of antiherding funds tend to yield superior performance. These results lend further support to the skill channel in explaining the link between herding and future performance. Differences in herding behavior identify differences in the subsequent trading decisions of mutual funds, which lead to differences in performance.

Overall, these robustness tests corroborate our evidence on the predictive power of fund herding 
for mutual fund performance, and further reinforce the link between fund herding, future performance, and managerial ability.

\section{Do Investors Respond to Fund Herding?}

In this section we ask whether mutual fund investors are aware of the predictability of fund performance associated with herding. In other words, we ask whether investors switch money out of herding funds, which have lower expected future performance, and into antiherding funds, which have higher expected future performance. To address this question we regress the percentage fund flows in quarter $t+1$ on a fund's herding tendency and a number of fund characteristics measured in quarter $t$. The results, reported in Table XV, indicate a generally negative but statistically insignificant relation between mutual fund herding and future fund flows. These findings suggest that, on average, mutual fund investors do not respond aggressively to the information about future performance that is captured by our measure of fund herding.

\section{[Insert Table XV about here]}

From a practical point of view, these results highlight the investment value of our fund herding measure for mutual fund investors: tilting their portfolio toward antiherding funds and away from herding funds could substantially improve their investment returns. From a theoretical point of view, these results may help explain the strong predictive ability of fund herding for mutual fund performance. In the equilibrium model of Berk and Green (2004), mutual fund investors react strongly to signals revealing managerial ability, such as past performance, actively switching money across mutual funds. As a result, in equilibrium, these signals have no forecasting power for fund

performance. The results of our test suggest that the inability of investors to fully appreciate the link between fund herding and managerial skill may help explain the significant forecasting power of fund herding documented in our paper.

\section{Conclusions}

In this paper we investigate the link between herding behavior and managerial ability in the mutual fund industry. We begin by creating a new, dynamic fund-level measure of herding to 
capture the intertemporal correlation between a manager's trades and past institutional trades, after accounting for the tendency of funds to invest in the same styles or engage in momentum trading. We then test whether this measure of fund herding can predict cross-sectional differences in mutual fund performance.

We find that herding behavior strongly and negatively predicts the cross-section of mutual fund returns. The top decile portfolio of funds with the highest herding tendency underperforms the bottom decile portfolio of antiherding funds by about $2.28 \%$ on an annualized basis, both before and after expenses. We obtain similar results when we adjust the fund returns to account for their risk exposures: the underperformance of herding funds is $1.92 \%$ based on Carhart (1997) four-factor alphas. Our regression results show that the predictive ability of fund herding is distinct from the effect of past performance, other fund characteristics, and other measures of skill.

We next provide further evidence that the negative association between fund herding and future performance is related to managerial skill. First, we find a large and significant return differential between the holdings of herding and antiherding funds, even after excluding stocks that are heavily traded by the institutional crowd, suggesting that antiherding funds make consistently better investment decisions than their herding peers. Second, we show that the performance gap between herding and antiherding funds is stronger in periods of greater investment opportunities for mutual fund managers, when skill is more valuable. Third, we show that this performance gap is persistent over long horizons. Fourth, we show that the trades of antiherding funds can anticipate those of the institutional crowd, suggesting that they might acquire information earlier than others.

To deepen our investigation of herding and skill, we study how the interaction between ability and career concerns shapes managers' reaction to reputational incentives. We find that the performance gap between herding and antiherding funds is especially strong among inexperienced managers, suggesting that herding and antiherding choices might be used to signal skill by managers with stronger career concerns.

Our analysis is inspired by the theoretical literature on sequential decision-making, which, under a range of different economic frameworks, points to a negative association between people's ability and their tendency to imitate past decisions. Consistent with the implications of these theoretical models, our findings establish a strong link between cross-sectional differences in skill and the dynamics of imitative behavior. The evidence presented in this paper calls for further investigations, both empirical and theoretical, of the role played by managerial ability in shaping 
sequential decision-making processes.

Initial submission: 17 April 2013; Accepted: 3 November 2017

Editors: Bruno Biais, Michael R. Roberts, and Kenneth J. Singleton 


\section{Notes}

${ }^{1}$ See, for example, Scharfstein and Stein (1990) for a model of reputational herding and Bikhchandani, Hirshleifer, and Welch (1992) and Banerjee (1992) for models of informational cascades. The relevant theoretical literature on herding behavior is reviewed in Section IV.

${ }^{2}$ Papers that document herding behavior among money managers and relate it to stock returns include Lakonishok, Shleifer, and Vishny (1992), Grinblatt, Titman, and Wermers (1995), Nofsinger and Sias (1999), Wermers (1999), Sias (2004), and Dasgupta, Prat, and Verardo (2011a).

${ }^{3}$ Fama and French (2010) find evidence of inferior and superior performance in the extreme tails of the cross-section of mutual fund alphas. Studies that develop measures of skill that identify extreme performers include Kacperczyk, Sialm, and Zheng (2005, 2008), Cohen, Coval, and Pástor (2005), Kacperczyk and Seru (2007), Cremers and Petajisto (2009), Cohen, Polk, and Silli (2010), and Pástor, Stambaugh, and Taylor (2017), among others.

${ }^{4}$ Models of herding behavior are inherently dynamic and involve an agent making a decision after observing the actions of other agents (e.g., Scharfstein and Stein (1990), Bikhchandani, Hirshleifer, and Welch (1992)). In empirical studies, institutional herding is typically measured either as the aggregate propensity of institutional investors to buy a given stock at the same time, or as the correlation of aggregate institutional demand over adjacent quarters. With these measures, it is difficult to capture both the nature and the implications of sequential decision making for individual funds.

${ }^{5}$ We consider active share (Cremers and Petajisto (2009)), reliance on public information (Kacperczyk and Seru (2007)), and similarity to funds with good past performance (Cohen, Coval, and Pástor (2005)).

${ }^{6}$ More recently, Eyster and Rabin (2014) show that rational agents who observe the actions of multiple predecessors become aware of the information redundancy conveyed by past herds and form beliefs of the opposite sign, exhibiting anti-imitation behavior.

${ }^{7}$ Mutual fund flows have been linked to price pressure and subsequent reversals in stock returns and fund performance. For empirical evidence, see Coval and Stafford (2007) and Lou (2012); for a theoretical analysis, see Vayanos and Woolley (2013).

${ }^{8}$ Grinblatt, Titman, and Wermers (1995) explore the link between mutual fund herding and performance. However, their analysis is based on the LSV stock-level measure of herding, that is, 
the fraction of funds buying and selling the same stock in the same quarter (Lakonishok, Shleifer, and Vishny (1992)), averaged across stocks for a given fund. Using data on 274 mutual funds during the period 1975 to 1985, they find that the association between this measure of herding and fund performance is subsumed by the tendency of mutual funds to buy past winners. In a similar framework, Wei, Wermers, and Yao (2015) aggregate the LSV stock-level measure of herding across stocks traded by a given fund and show that funds with a lower herding measure (higher contrarian measure) outperform the rest of the funds.

${ }^{9}$ We exclude funds with any of the following investment objectives as provided by Thomson Reuters: International, Municipal Bonds, Bond and Preferred, and Balanced. Furthermore, we use the portfolio composition data provided by CRSP to exclude funds that on average invest less than $80 \%$ or more than $105 \%$ in common equity. Our sample starts in 1990 because of the small number of funds in the earlier period of the sample. Specifically, at the start of 1984, we have 102 distinct mutual funds; the number grows to 174 at the start of 1990 and increases to 1,230 at the end of 2009.

${ }^{10}$ All institutions with more than $\$ 100$ million under discretionary management are required to report to the SEC all equity positions greater than either 10,000 shares or $\$ 200,000$ in market value.

${ }^{11}$ In the empirical literature on institutional investors, Sias (2004) emphasizes the need to consider the dynamic nature of herding. He measures institutional demand for a stock by the fraction of institutional traders who are buyers (similar to LSV). He then defines aggregate institutional herding as the slope coefficient from a cross-sectional regression of institutional demand in quarter $t$ on institutional demand in quarter $t-1$. Dasgupta, Prat, and Verardo (2011a) construct a stocklevel measure of herding based on persistent institutional buying or selling activity for the same stock over a number of consecutive quarters.

${ }^{12}$ We do not consider initiations of new positions or deletions of current ones, that is, we require a fund to have nonzero holdings at the beginning and at the end of a quarter to compute a trade in a given stock. However, our results do not change if we include these trades, as we show in the Internet Appendix. The Internet Appendix is available in the online version of the article on The Journal of Finance website.

${ }^{13}$ This choice is motivated by Sias (2004), who standardizes the dependent and independent variables in cross-sectional regressions of institutional demand over adjacent quarters. We obtain similar results if we do not standardize the variables in the trade regressions, as we show in the 
Internet Appendix.

${ }^{14}$ This type of inverse-weighting scheme is often used in the literature. For example, Chen and Jiang (2006) apply it to compute a consensus measure from analyst forecasts that are issued up to a given date, assigning higher weights to more recent forecasts as they contain more updated information. In the Internet Appendix we show that the results of our analysis are qualitatively similar if we define fund herding as the simple quarterly beta or as the equally weighted average of betas over the lifetime of a fund.

${ }^{15}$ Measured over the lifetime of the average fund in our sample, the standard deviation of betas is $17.43 \%$. After averaging the betas as in (2), the standard deviation of fund herding over the lifetime of a fund is $5.72 \%$.

${ }^{16}$ These three measures are constructed as follows. Active Share is computed as the fraction of the fund's portfolio holdings that differs from its benchmark index holdings. Reliance on public information, $R P I$, is the $R^{2}$ of a regression of fund trades on changes in analyst stock recommendations, specified as in Kacperczyk and Seru (2007). For robustness we also compute an alternative measure of reliance on public information using the $R^{2}$ from our trade regressions (1). We obtain similar results. Similarity is constructed as in Cohen, Coval, and Pástor (2005). Specifically, each quarter we first construct a proxy for the quality of a given stock by averaging the prior three-year Fama-French alpha of all funds trading the stock using the portfolio weights they place on the stock. We then aggregate the quality of all stocks traded by a given fund, based on its portfolio composition, to obtain a quarterly fund-level measure of quality. We obtain similar results if we use the holdings-based measure of Cohen, Coval, and Pástor (2005) rather than their trades-based measure (see also Pomorski (2009)).

${ }^{17}$ Following Petersen (2009) and Thompson (2011), we also consider two-way clustering by both funds and time and obtain similar results.

${ }^{18}$ In the pooled sample, the standard deviation of $F H_{j, t}$ is 0.0698 .

${ }^{19}$ In the Internet Appendix we show that changes in institutional ownership, $\Delta I O$, do not predict stock returns in a way that can explain the performance gap between herding and antiherding funds. In particular, $\Delta I O$ does not predict price pressure or return reversals in the periods in which we measure fund performance.

${ }^{20}$ We obtain the index from the Frank Russell Company.

${ }^{21}$ The empirical evidence generally supports the hypothesis that managerial experience attenuates 
the incentives to herd. For example, Chevalier and Ellison (1999) document that younger mutual fund managers herd more than their older peers. Hong, Kubik, and Solomon (2000) find that younger security analysts deviate less from the consensus forecast of firms' earnings. Analyzing a sample of macroeconomic forecasters, Lamont (2002) finds that younger forecasters herd more than older ones.

${ }^{22}$ Other models of reputational herding in different settings include, for example, Trueman (1994), Zwiebel (1995), Graham (1999), and Dasgupta, Prat and Verardo (2011b).

${ }^{23}$ Terminations occur in 1,482 manager-quarters, out of 19,387 manager-quarters in our sample - on average, the probability of termination is 7.64\%. Chevalier and Ellison use a slightly broader definition of termination that includes cases in which managers leave a fund to join a smaller and possibly team-managed fund. However, when they define terminations as we do, they report 98 manager-year occurrences, which represents $7.42 \%$ of their sample.

${ }^{24}$ In the Internet Appendix we report a more comprehensive set of robustness tests. For example, we construct an alternative measure of fund herding starting from the LSV measure, that is, from the fraction of funds that buy the same stock at the same time. We find that this measure does not predict mutual fund performance, confirming that the predictive ability of our measure of fund herding relies on its fund-specific, dynamic character. Furthermore, we construct an alternative measure of fund herding defined as the tendency to imitate the trades of a subset of successful mutual funds. We find that this measure does not predict fund performance, which highlights the importance of using the tendency to follow the broad crowd of investors as a signal to separate skilled and unskilled mutual funds.

${ }^{25}$ See, for example, Gervais, Kaniel, and Mingelgrin (2001) on trading volume, Ang et al. (2006) on idiosyncratic volatility, Gleason and Lee (2003) on analyst earnings forecast revisions, Daniel and Titman (2006) on share issuance, and Kacperczyk, Sialm, and Zheng (2005) on industry concentration.

${ }^{26}$ For example, Sirri and Tufano (1998) and Chevalier and Ellison (1997) provide evidence of persistent mutual fund flows. Mutual funds could also split their trades over time to reduce their price impact. Coval and Stafford (2007) and Lou (2012) investigate the impact of mutual fund flows on stock returns and fund performance, and find evidence of initial price pressure and subsequent reversals. 


\section{REFERENCES}

Amihud, Yakov, 2002, Illiquidity and stock returns: Cross-section and time-series effects, Journal of Financial Markets 5, 31-56.

Ang, Andrew, Robert Hodrick, Yuhang Xing, and Xiaoyan Zhang, 2006, The cross-section of volatility and expected returns, Journal of Finance 51, 259-299.

Ankrim, Ernes M., and Zhuanxin Ding, 2002, Cross-sectional volatility and return dispersion, Financial Analysts Journal 58, 67-72.

Avery, Christopher N., and Judith A. Chevalier, 1999, Herding over the career, Economics Letters $63,327-333$.

Baker, Malcolm, and Jeffrey Wurgler, 2006, Investor sentiment and the cross-section of stock returns, Journal of Finance 61, 1645-1680.

Banerjee, Abhijit V., 1992, A simple model of herd behavior, Quarterly Journal of Economics 107, 797-817.

Barberis, Nicholas, and Andrei Shleifer, 2003, Style investing, Journal of Financial Economics 68, 161-199.

Bennett, James A., Richard W. Sias, and Laura T. Starks, 2003, Greener pastures and the impact of dynamic institutional preferences, Review of Financial Studies 16, 1203-1238.

Berk, Jonathan B., and Richard C. Green, 2004, Mutual fund flows and performance in rational markets, Journal of Political Economy 112, 1269-1295.

Bikhchandani, Sushil, David Hirshleifer, and Ivo Welch, 1992, A theory of fads, fashion, custom, and cultural change as information cascades, Journal of Political Economy 100, 992-1026.

Carhart, Mark M., 1997, On persistence in mutual fund performance, Journal of Finance 52, 57-82. Chen, Joseph, Harrison Hong, Ming Huang, and Jeffrey D. Kubik, 2004, Does fund size erode mutual fund performance? The role of liquidity and organization, American Economic Review 94, 1276-1302.

Chen, Qi, and Wei Jiang, 2006, Analysts' weighting of private and public information, Review of Financial Studies 19, 319-355.

Chevalier, Judith, and Glenn Ellison, 1997, Risk taking by mutual funds as a response to incentives, Journal of Political Economy 105, 1167-1200.

Chevalier, Judith, and Glenn Ellison, 1999, Career concerns of mutual fund managers, Quarterly 
Journal of Economics 114, 389-432.

Choi, Nicole, and Richard W. Sias, 2009, Institutional industry herding, Journal of Financial Economics 94, 469-491.

Cohen, Randolph B., Joshua D. Coval, and Lubos Pástor, 2005, Judging fund managers by the company that they keep, Journal of Finance 60, 1057-1096.

Cohen, Randolph B., Christopher Polk, and Bernhard Silli, 2010, Best ideas, Working paper, London School of Economics.

Coval, Joshua D., and Erik Stafford, 2007, Asset fire sales (and purchases) in equity markets, Journal of Financial Economics 86, 479-512.

Cremers, Martijn, and Antti Petajisto, 2009, How active is your fund manager? A new measure that predicts performance, Review of Financial Studies 22, 3329-3365.

Daniel, Kent, Mark Grinblatt, Sheridan Titman, and Russ Wermers, 1997, Measuring mutual fund performance with characteristic-based benchmarks, Journal of Finance 52, 1035-1058.

Daniel, Kent, and Sheridan Titman, 2006, Market reactions to tangible and intangible information, Journal of Finance 61, 1605-1643.

Dasgupta, Amil, Andrea Prat, and Michela Verardo, 2011a, Institutional trade persistence and long-term equity returns, Journal of Finance 66, 635-653.

Dasgupta, Amil, Andrea Prat, and Michela Verardo, 2011b, The price impact of institutional herding, Review of Financial Studies 24, 892-925.

Elton, Edwin J., Martin J. Gruber, and Christopher R. Blake, 2001, A first look at the accuracy of the CRSP mutual fund database and a comparison of the CRSP and Morningstar mutual fund databases, Journal of Finance 56, 2415-2430.

Evans, Richard B., 2010, Mutual fund incubation, Journal of Finance 65, 1581-1611.

Eyster, Erik, and Matthew Rabin, 2014, Extensive imitation is irrational and harmful, Quarterly Journal of Economics 129, 1861-1898.

Fama, Eugene, and Kenneth R. French, 1993, Common risk factors in the returns on stocks and bonds, Journal of Financial Economics 33, 3-56.

Fama, Eugene, and Kenneth R. French, 2010, Luck versus skill in the cross-section of mutual fund returns, Journal of Finance 65, 1915-1947.

Fama, Eugene, and James MacBeth, 1973, Risk, return, and equilibrium: Empirical tests, Journal of Political Economy 81, 607-636. 
Ferson, Wayne E., and Rudi W. Schadt, 1996, Measuring fund strategy and performance in changing economic conditions, Journal of Finance 51, 425-461.

Froot, Kenneth A., David S. Scharfstein, and Jeremy C. Stein, 1992, Herd on the street: Informational inefficiencies in a market with short-term speculation, Journal of Finance 47, 1461-1484.

Froot, Kenneth A., and Melvyn Teo, 2008, Style investing and institutional investors, Journal of Financial and Quantitative Analysis 43, 883-906.

Gervais, Simon, Ron Kaniel, and Dan H. Mingelgrin, 2001, The high volume return premium, Journal of Finance 56, 877-920.

Gleason, Cristi, and Charles M.C. Lee, 2003, Analyst forecast revisions and market price recovery, Accounting Review 78, 193-225.

Gompers, Paul A., and Andrew Metrick, 2001, Institutional investors and equity prices, Quarterly Journal of Economics 116, 229-259.

Graham, John R., 1999, Herding among investment newsletters: Theory and evidence, Journal of Finance 54, 237-268.

Grinblatt, Mark, and Sheridan Titman, 1993, Performance measurement without benchmarks: An examination of mutual fund returns, Journal of Business 66, 47-68.

Grinblatt, Mark, Sheridan Titman, and Russ Wermers, 1995, Momentum investment strategies, portfolio performance, and herding: A study of mutual fund behavior, American Economic Review 85, 1088-1105.

Gruber, Martin J., 1996, Another puzzle: The growth in actively managed mutual funds, Journal of Finance 51, 783-810.

Hirshleifer, David, Avanidhar Subrahmanyam, and Sheridan Titman, 1994, Security analysis and trading patterns when some investors receive information before others, Journal of Finance 49, 1665-1698.

Hong, Harrison, Jeffrey D. Kubik, and Amit Solomon, 2000, Security analysts' career concerns and herding of earnings forecasts, Rand Journal of Economics 31, 121-144.

Jiang, Hao, 2010, Institutional investors, intangible information, and the book-to-market effect, Journal of Financial Economics 96, 98-126.

Kacperczyk, Marcin, and Amit Seru, 2007, Fund manager use of public information: New evidence on managerial skills, Journal of Finance 62, 485-528.

Kacperczyk, Marcin, Clemens Sialm, and Lu Zheng, 2005, On the industry concentration of actively 
managed equity mutual funds, Journal of Finance 60, 1983-2012.

Kacperczyk, Marcin, Clemens Sialm, and Lu Zheng, 2008, Unobserved actions of mutual funds, Review of Financial Studies 21, 2379-2416.

Kacperczyk, Marcin, Stijn Van Nieuwerburgh, and Laura Veldkamp, 2014, Time-varying fund manager skill, Journal of Finance, 1455-1484.

Kacperczyk, Marcin, Stijn Van Nieuwerburgh, and Laura Veldkamp, 2016, A rational theory of mutual funds' attention allocation, Econometrica 84, 571-626.

Lakonishok, Josef, Andrei Shleifer, and Robert W. Vishny, 1992, The impact of institutional trading on stock prices, Journal of Financial Economics 32, 23-43.

Lamont, Owen A., 2002, Macroeconomic forecasts and microeconomic forecasters, Journal of Economic Behavior \& Organization 48, 265-280.

Lou, Dong, 2012, A flow-based explanation for return predictability, Review of Financial Studies $25,3457-3489$.

Newey, Whitney K., and Kenneth D. West, 1987, A simple, positive semi-definite, heteroskedasticity and autocorrelation consistent covariance matrix, Econometrica 55, 703-708.

Nofsinger, John, and Richard Sias, 1999, Herding and feedback trading by institutional and individual investors, Journal of Finance 54, 2263-2295.

Pástor, Lubos, and Robert F. Stambaugh, 2003, Liquidity risk and expected stock returns, Journal of Political Economy 111, 642-685.

Pástor, Lubos, Robert F. Stambaugh, and Lucian A. Taylor, 2017, Do funds make more when they trade more?, Journal of Finance 72, 1483-1528.

Petajisto, Antti, 2013, Active share and mutual fund performance, Financial Analysts Journal 69, 73-93.

Petersen, Mitchell A., 2009, Estimating standard errors in finance panel data sets: Comparing approaches, Review of Financial Studies 22, 435-480.

Pomorski, Lukasz, 2009, Follow the leader: Peer effects in mutual fund portfolio decisions, Working Paper, AQR Capital Management, LLC.

Prendergast, Canice, and Lars Stole, 1996, Impetuous youngsters and jaded old-timers: Acquiring a reputation for learning, Journal of Political Economy 104, 1105-1134.

Scharfstein, David, and Jeremy Stein, 1990, Herd behavior and investment, American Economic Review 80, 465-479. 
Sias, Richard, 2004, Institutional Herding, Review of Financial Studies 17, 165-206.

Sirri, Erik R., and Peter Tufano, 1998, Costly search and mutual fund flows, Journal of Finance $53,1589-1622$.

Thompson, Samuel B., 2011, Simple formulas for standard errors that cluster by both firm and time, Journal of Financial Economics 99, 1-10.

Trueman, Brett, 1994, Analyst forecasts and herding behavior, Review of Financial Studies 7, $97-124$.

Vayanos, Dimitri, and Paul Woolley, 2013, An institutional theory of momentum and reversal, Review of Financial Studies 26, 1087-1145.

Wei, Kelsei D., Russ Wermers, and Tong Yao, 2015, Uncommon value: The characteristics and investment performance of contrarian funds, Management Science 61, 2394-2414.

Wermers, Russ, 1999, Mutual fund herding and the impact on stock prices, Journal of Finance 54, 581-622.

Zheng, Lu, 1999, Is money smart? A study of mutual fund investors' fund selection ability, Journal of Finance 54, 901-993.

Zwiebel, Jeffrey, 1995, Corporate conservatism and relative compensation, Journal of Political Economy 103, 1-25. 
Table I

\section{Summary Statistics}

This table presents descriptive statistics for the sample of actively managed mutual funds analyzed in this paper. The sample consists of 2,255 distinct mutual funds over the period 1990 to 2009. Panel A presents summary statistics for fund characteristics. Fund Size is quarter-end total net fund assets in millions of dollars; Fund Age is the number of years a fund is present in the CRSP mutual fund database; Expense is the fund's expense ratio; Turnover is the turnover ratio of the fund; Quarterly Flow is the quarterly growth rate of assets under management after adjusting for the appreciation of the fund's assets; and Quarterly Return is the quarterly net fund return. Panel B presents summary statistics for $\beta$ and Fund Herding, $F H . \beta$ is the slope coefficient from fund-specific quarterly regressions of mutual fund trades on past aggregate institutional trades measured in the previous quarter, controlling for past stock returns, firm size, and the book-to-market ratio. Both the dependent and the independent variables are cross-sectionally standardized to have means of zero and standard deviations of one for each fund in each quarter. To construct fund-level herding, $F H$, we average the quarterly coefficients $\beta$ over the lifetime of each fund up to quarter $t$, using a rank inverse-weighting scheme that assigns higher weight to more recent quarters. All statistics are computed across funds in each quarter and then averaged over time.

\begin{tabular}{|c|c|c|c|c|c|c|c|}
\hline \multicolumn{8}{|c|}{ Panel A: Fund Characteristics } \\
\hline & Mean & Std Dev & v $\quad 5^{\text {th }}$ Pctl & $25^{\text {th }}$ Pctl & Median & $75^{\text {th }}$ Pctl & $95^{\text {th }}$ Pctl \\
\hline Fund Size (TNA) & 1605.29 & 5602.45 & 18.07 & 94.80 & 322.60 & 1093.25 & 6380.60 \\
\hline Fund Age & 17.63 & 14.56 & 5.00 & 8.00 & 12.50 & 21.00 & 51.00 \\
\hline Expense & 0.013 & 0.005 & 0.007 & 0.010 & 0.012 & 0.015 & 0.020 \\
\hline Turnover & 0.851 & 0.858 & 0.110 & 0.340 & 0.646 & 1.100 & 2.230 \\
\hline Quarterly Flow & 0.013 & 1.583 & -0.121 & -0.044 & -0.014 & 0.023 & 0.169 \\
\hline Quarterly Return & 0.016 & 0.105 & -0.177 & -0.036 & 0.021 & 0.074 & 0.176 \\
\hline \multicolumn{8}{|c|}{ Panel B: Estimates of $\beta$ and Fund Herding (\%) } \\
\hline \multicolumn{8}{|c|}{ Cross-Sectional Statistics (average over 80 quarters) } \\
\hline & Mean & Std Dev & $5^{\text {th }}$ Pctl & $25^{\text {th }}$ Pctl & Median & $75^{\text {th }}$ Pctl & $95^{\text {th }}$ Pctl \\
\hline$\beta$ & 2.30 & 18.73 & -27.84 & -7.83 & 2.15 & 12.62 & 32.63 \\
\hline Fund Herding & 2.42 & 7.12 & -8.81 & -1.51 & 2.35 & 6.39 & 13.86 \\
\hline
\end{tabular}




\section{Table II}

\section{Fund Herding and Future Performance: Portfolios}

This table presents the performance of decile portfolios formed on the basis of Fund Herding $(F H)$, the average tendency of mutual funds to follow past institutional trades. FH is constructed from the slope coefficient of cross-sectional regressions of mutual fund trades on aggregate institutional trades measured in the previous quarter, controlling for past stock returns, firm size, and the book-to-market ratio. We average these quarterly slope coefficients through a rank inverse-weighting scheme, assigning higher weights to more recent quarters. The decile portfolios are formed at the end of each quarter from 1989Q4 to 2009Q3 and held for one quarter. The resulting monthly return series span January 1990 to December 2009. Decile 10 is the portfolio of funds with the highest average herding measure. We compute equally weighted net and gross (net plus expense ratio) returns on the portfolios, as well as risk-adjusted returns based on the CAPM, the Fama and French (1993, FF) three-factor model, the Carhart (1997) four-factor model, the Pastor and Stambaugh (2003, PS) five-factor model, and the Ferson and Schadt $(1996, \mathrm{FS})$ conditional model. We report average returns and alphas in monthly percentages. Newey-West (1987) $t$-statistics are shown in parentheses. $* * *, * *$, and $*$ denote statistical significance at the $1 \%, 5 \%$, and $10 \%$ level, respectively, for the return differentials between deciles 10 and 1 . 


\begin{tabular}{|c|c|c|c|c|c|c|c|c|c|c|c|}
\hline FH rank & 1 & 2 & 3 & 4 & 5 & 6 & 7 & 8 & 9 & 10 & D10-D1 \\
\hline FH & -0.104 & -0.041 & -0.016 & 0.002 & 0.017 & 0.031 & 0.046 & 0.064 & 0.089 & 0.152 & 0.256 \\
\hline \multicolumn{12}{|c|}{ Net Return } \\
\hline Average & $\begin{array}{c}0.84 \\
(2.91)\end{array}$ & $\begin{array}{c}0.80 \\
(2.76)\end{array}$ & $\begin{array}{c}0.80 \\
(2.78)\end{array}$ & $\begin{array}{c}0.79 \\
(2.76)\end{array}$ & $\begin{array}{c}0.78 \\
(2.69)\end{array}$ & $\begin{array}{c}0.74 \\
(2.55)\end{array}$ & $\begin{array}{c}0.75 \\
(2.55)\end{array}$ & $\begin{array}{c}0.77 \\
(2.60)\end{array}$ & $\begin{array}{c}0.69 \\
(2.30)\end{array}$ & $\begin{array}{c}0.65 \\
(2.18)\end{array}$ & $\begin{array}{c}-0.19 * * * \\
(-3.37)\end{array}$ \\
\hline CAPM $\alpha$ & $\begin{array}{c}0.07 \\
(1.07)\end{array}$ & $\begin{array}{c}0.03 \\
(0.48)\end{array}$ & $\begin{array}{c}0.03 \\
(0.52)\end{array}$ & $\begin{array}{c}0.02 \\
(0.37)\end{array}$ & $\begin{array}{c}0.01 \\
(0.10)\end{array}$ & $\begin{array}{c}-0.04 \\
(-0.69)\end{array}$ & $\begin{array}{c}-0.03 \\
(-0.65)\end{array}$ & $\begin{array}{c}-0.01 \\
(-0.27)\end{array}$ & $\begin{array}{l}-0.10 \\
(-1.76)\end{array}$ & $\begin{array}{c}-0.14 \\
(-2.58)\end{array}$ & $\begin{array}{c}-0.21 * * * \\
(-3.71)\end{array}$ \\
\hline $\mathrm{FF} \alpha$ & $\begin{array}{c}0.02 \\
(0.31)\end{array}$ & $\begin{array}{c}-0.02 \\
(-0.40)\end{array}$ & $\begin{array}{l}-0.02 \\
(-0.46)\end{array}$ & $\begin{array}{c}-0.03 \\
(-0.67)\end{array}$ & $\begin{array}{c}-0.04 \\
(-0.96)\end{array}$ & $\begin{array}{c}-0.08 \\
(-1.85)\end{array}$ & $\begin{array}{c}-0.06 \\
(-1.46)\end{array}$ & $\begin{array}{c}-0.04 \\
(-0.81)\end{array}$ & $\begin{array}{l}-0.11 \\
(-2.21)\end{array}$ & $\begin{array}{c}-0.15 \\
(-3.06)\end{array}$ & $\begin{array}{c}-0.17 * * * \\
(-3.26)\end{array}$ \\
\hline Carhart $\alpha$ & $\begin{array}{c}0.01 \\
(0.20)\end{array}$ & $\begin{array}{c}-0.03 \\
(-0.50)\end{array}$ & $\begin{array}{l}-0.02 \\
(-0.42)\end{array}$ & $\begin{array}{l}-0.05 \\
(-0.92)\end{array}$ & $\begin{array}{c}-0.05 \\
(-1.20)\end{array}$ & $\begin{array}{l}-0.07 \\
(-1.55)\end{array}$ & $\begin{array}{l}-0.06 \\
(-1.33)\end{array}$ & $\begin{array}{l}-0.03 \\
(-0.57)\end{array}$ & $\begin{array}{l}-0.12 \\
(-2.34)\end{array}$ & $\begin{array}{c}-0.14 \\
(-2.59)\end{array}$ & $\begin{array}{c}-0.16^{* * *} \\
(-2.93)\end{array}$ \\
\hline PS $\alpha$ & $\begin{array}{c}0.00 \\
(0.02)\end{array}$ & $\begin{array}{c}-0.04 \\
(-0.73)\end{array}$ & $\begin{array}{c}-0.03 \\
(-0.56)\end{array}$ & $\begin{array}{l}-0.06 \\
(-1.12)\end{array}$ & $\begin{array}{l}-0.05 \\
(-1.18)\end{array}$ & $\begin{array}{c}-0.07 \\
(-1.48)\end{array}$ & $\begin{array}{l}-0.06 \\
(-1.22)\end{array}$ & $\begin{array}{c}-0.02 \\
(-0.41)\end{array}$ & $\begin{array}{l}-0.12 \\
(-2.23)\end{array}$ & $\begin{array}{c}-0.14 \\
(-2.58)\end{array}$ & $\begin{array}{c}-0.14 * * * \\
(-2.67)\end{array}$ \\
\hline $\mathrm{FS} \alpha$ & $\begin{array}{c}-0.02 \\
(-0.34) \\
\end{array}$ & $\begin{array}{c}-0.09 \\
(-1.88) \\
\end{array}$ & $\begin{array}{c}-0.05 \\
(-1.24) \\
\end{array}$ & $\begin{array}{c}-0.08 \\
(-1.64) \\
\end{array}$ & $\begin{array}{c}-0.07 \\
(-2.02) \\
\end{array}$ & $\begin{array}{c}-0.11 \\
(-3.03) \\
\end{array}$ & $\begin{array}{c}-0.09 \\
(-2.12) \\
\end{array}$ & $\begin{array}{c}-0.07 \\
(-1.63) \\
\end{array}$ & $\begin{array}{c}-0.14 \\
(-3.20)\end{array}$ & $\begin{array}{c}-0.19 \\
(-4.18)\end{array}$ & $\begin{array}{c}-0.17 * * * \\
(-3.18)\end{array}$ \\
\hline \multicolumn{12}{|c|}{ Gross Return } \\
\hline Average & $\begin{array}{c}0.95 \\
(3.31)\end{array}$ & $\begin{array}{c}0.91 \\
(3.12)\end{array}$ & $\begin{array}{c}0.90 \\
(3.14)\end{array}$ & $\begin{array}{c}0.89 \\
(3.10)\end{array}$ & $\begin{array}{c}0.88 \\
(3.02)\end{array}$ & $\begin{array}{c}0.84 \\
(2.89)\end{array}$ & $\begin{array}{c}0.85 \\
(2.90)\end{array}$ & $\begin{array}{c}0.87 \\
(2.94)\end{array}$ & $\begin{array}{c}0.79 \\
(2.65)\end{array}$ & $\begin{array}{c}0.76 \\
(2.56)\end{array}$ & $\begin{array}{c}-0.19 * * * \\
(-3.38)\end{array}$ \\
\hline $\mathrm{CAPM} \alpha$ & $\begin{array}{c}0.19 \\
(2.74)\end{array}$ & $\begin{array}{c}0.13 \\
(2.10)\end{array}$ & $\begin{array}{c}0.13 \\
(2.24)\end{array}$ & $\begin{array}{c}0.12 \\
(1.93)\end{array}$ & $\begin{array}{c}0.10 \\
(2.02)\end{array}$ & $\begin{array}{c}0.06 \\
(1.24)\end{array}$ & $\begin{array}{c}0.07 \\
(1.36)\end{array}$ & $\begin{array}{c}0.09 \\
(1.65)\end{array}$ & $\begin{array}{c}0.00 \\
(0.07)\end{array}$ & $\begin{array}{c}-0.02 \\
(-0.47)\end{array}$ & $\begin{array}{c}-0.21 * * * \\
(-3.72)\end{array}$ \\
\hline $\mathrm{FF} \alpha$ & $\begin{array}{c}0.13 \\
(2.37)\end{array}$ & $\begin{array}{c}0.08 \\
(1.59)\end{array}$ & $\begin{array}{c}0.08 \\
(1.60)\end{array}$ & $\begin{array}{c}0.07 \\
(1.37)\end{array}$ & $\begin{array}{c}0.06 \\
(1.63)\end{array}$ & $\begin{array}{c}0.02 \\
(0.50)\end{array}$ & $\begin{array}{c}0.04 \\
(0.83)\end{array}$ & $\begin{array}{c}0.06 \\
(1.29)\end{array}$ & $\begin{array}{l}-0.01 \\
(-0.19)\end{array}$ & $\begin{array}{c}-0.04 \\
(-0.79)\end{array}$ & $\begin{array}{c}-0.17 * * * \\
(-3.27)\end{array}$ \\
\hline Carhart $\alpha$ & $\begin{array}{c}0.12 \\
(2.08)\end{array}$ & $\begin{array}{c}0.08 \\
(1.41)\end{array}$ & $\begin{array}{c}0.08 \\
(1.52)\end{array}$ & $\begin{array}{c}0.05 \\
(1.03)\end{array}$ & $\begin{array}{c}0.05 \\
(1.25)\end{array}$ & $\begin{array}{c}0.03 \\
(0.77)\end{array}$ & $\begin{array}{c}0.04 \\
(0.82)\end{array}$ & $\begin{array}{c}0.07 \\
(1.44)\end{array}$ & $\begin{array}{l}-0.02 \\
(-0.37)\end{array}$ & $\begin{array}{c}-0.03 \\
(-0.59)\end{array}$ & $\begin{array}{c}-0.16^{* * *} \\
(-2.95)\end{array}$ \\
\hline $\operatorname{PS} \alpha$ & $\begin{array}{c}0.11 \\
(1.93)\end{array}$ & $\begin{array}{c}0.06 \\
(1.16)\end{array}$ & $\begin{array}{c}0.07 \\
(1.32)\end{array}$ & $\begin{array}{c}0.04 \\
(0.83)\end{array}$ & $\begin{array}{c}0.05 \\
(1.18)\end{array}$ & $\begin{array}{c}0.03 \\
(0.75)\end{array}$ & $\begin{array}{c}0.04 \\
(0.89)\end{array}$ & $\begin{array}{c}0.08 \\
(1.52)\end{array}$ & $\begin{array}{l}-0.02 \\
(-0.33)\end{array}$ & $\begin{array}{c}-0.03 \\
(-0.55)\end{array}$ & $\begin{array}{c}-0.14 * * * \\
(-2.69)\end{array}$ \\
\hline FS $\alpha$ & $\begin{array}{c}0.10 \\
(2.02)\end{array}$ & $\begin{array}{c}0.01 \\
(0.31)\end{array}$ & $\begin{array}{c}0.05 \\
(1.12)\end{array}$ & $\begin{array}{c}0.02 \\
(0.32)\end{array}$ & $\begin{array}{c}0.03 \\
(0.71)\end{array}$ & $\begin{array}{c}-0.01 \\
(-0.20)\end{array}$ & $\begin{array}{c}0.01 \\
(0.21)\end{array}$ & $\begin{array}{c}0.03 \\
(0.70)\end{array}$ & $\begin{array}{c}-0.04 \\
(-0.81)\end{array}$ & $\begin{array}{l}-0.08 \\
(-1.71)\end{array}$ & $\begin{array}{c}-0.17 * * * \\
(-3.23)\end{array}$ \\
\hline
\end{tabular}




\section{Table III \\ Determinants of Fund Herding}

This table shows the estimated coefficients from Fama-MacBeth (1973) regressions of Fund Herding on fund characteristics. Fund Herding is constructed from cross-sectional regressions of mutual fund trades on past aggregate institutional trades, as described in Table I. Size is the natural log of the quarter-end total net fund assets; Age is the natural log of fund age in years; Expense is the fund expense ratio; Turnover is the turnover ratio of the fund; Flow is the fund flow in the previous quarter; Alpha is the fund's three-factor alpha estimated over the previous three years; Active Share (AS) is the share of a fund's holdings that differ from the benchmark index holdings, as in Cremers and Petajisto (2009); RPI is the responsiveness of funds' trades to public information, as in Kacperczyk and Seru (2007); Similarity is the degree to which a fund's investment decisions resemble those of successful funds, as in Cohen Coval and Pastor (2005); and Tracking Error (TE) is the standard deviation of the residuals from regressions of monthly excess fund returns on monthly excess stock market returns over the previous year. The regressors are standardized to have a mean of zero and a standard deviation of one in each quarter. Newey-West (1987) $t$-statistics are shown in parentheses. $* * *, * *$, and $*$ denote statistical significance at the $1 \%, 5 \%$, and $10 \%$ level, respectively.

\begin{tabular}{|c|c|c|c|}
\hline \multicolumn{4}{|c|}{ Dependent Variable: Fund Herding } \\
\hline Size & $\begin{array}{l}-0.081 \\
(-1.08)\end{array}$ & $\begin{array}{l}-0.079 \\
(-1.10)\end{array}$ & $\begin{array}{l}-0.081 \\
(1.09)\end{array}$ \\
\hline Age & $\begin{array}{c}0.250^{* * *} \\
(3.21)\end{array}$ & $\begin{array}{c}0.274 * * * \\
(2.98)\end{array}$ & $\begin{array}{c}0.235^{* * * *} \\
(2.95)\end{array}$ \\
\hline Expense & $\begin{array}{l}-0.051 \\
(-1.02)\end{array}$ & $\begin{array}{l}0.063 \\
(1.31)\end{array}$ & $\begin{array}{l}0.004 \\
(0.08)\end{array}$ \\
\hline Turnover & $\begin{array}{c}-0.256^{* *} \\
(-2.51)\end{array}$ & $\begin{array}{l}-0.229^{*} \\
(-1.69)\end{array}$ & $\begin{array}{c}-0.221 * * \\
(2.28)\end{array}$ \\
\hline Flow & $\begin{array}{l}-0.008 \\
(-0.10)\end{array}$ & $\begin{array}{l}-0.083 \\
(-0.65)\end{array}$ & $\begin{array}{l}-0.011 \\
(0.13)\end{array}$ \\
\hline Alpha & $\begin{array}{l}0.133 \\
(1.11)\end{array}$ & $\begin{array}{l}0.176 \\
(1.16)\end{array}$ & $\begin{array}{l}0.144 \\
(1.14)\end{array}$ \\
\hline AS & & $\begin{array}{c}-0.548 * * * \\
(-4.51)\end{array}$ & \\
\hline RPI & & $\begin{array}{c}0.412 * * * \\
(3.87)\end{array}$ & \\
\hline Similarity & & $\begin{array}{l}-0.202^{*} \\
(-1.74)\end{array}$ & \\
\hline TE & & & $\begin{array}{c}-0.230^{*} \\
(1.68)\end{array}$ \\
\hline Adj $R^{2}$ & 0.010 & 0.026 & 0.015 \\
\hline $\mathrm{N}$ & 56116 & 27310 & 53348 \\
\hline
\end{tabular}




\section{Table IV}

\section{Fund Herding and Future Performance: Predictive Regressions}

This table presents coefficient estimates from predictive panel regressions estimating the association between Fund Herding and future fund performance. Fund Herding $(\mathrm{FH})$ is constructed from cross-sectional regressions of mutual fund trades on past aggregate institutional trades, as described in Table I. Future mutual fund performance is measured using the Carhart (1997) four-factor alpha (both net and gross, in monthly percentages); factor loadings are estimated from rolling-window regressions over the previous three years. The panel regressions control for fund size, fund age, expense ratio (in percent), fund turnover, fund percentage flows in the previous quarter, fund alpha (in percent) estimated over the previous three years, active share, reliance on public information, similarity with the investment decisions of successful funds, and tracking error; the control variables are described in Table III. The regressions include time fixed effects and the standard errors are clustered by fund. $t$-statistics are shown in parentheses. ***, **, and * denote statistical significance at the $1 \%, 5 \%$, and $10 \%$ level, respectively.

\begin{tabular}{|c|c|c|c|c|c|c|c|c|}
\hline \multirow[b]{2}{*}{$\mathrm{FH}$} & \multicolumn{4}{|c|}{ Four-Factor Net $\alpha(t+1)$} & \multicolumn{4}{|c|}{ Four-Factor Gross $\alpha(t+1)$} \\
\hline & $\begin{array}{c}-0.466^{* * *} \\
(-5.16)\end{array}$ & $\begin{array}{c}-0.438^{* * *} \\
(-4.83)\end{array}$ & $\begin{array}{c}-0.543 * * * \\
(-4.36)\end{array}$ & $\begin{array}{c}-0.439 * * * \\
(-4.84)\end{array}$ & $\begin{array}{c}-0.469^{* * *} \\
(-5.18)\end{array}$ & $\begin{array}{c}-0.437 * * * \\
(-4.82)\end{array}$ & $\begin{array}{c}-0.541 * * * \\
(-4.35)\end{array}$ & $\begin{array}{c}-0.438 * * * \\
(-4.82)\end{array}$ \\
\hline Size & & $\begin{array}{c}-0.007 * * \\
(-2.01)\end{array}$ & $\begin{array}{c}-0.011^{* *} \\
(-2.37)\end{array}$ & $\begin{array}{c}-0.006^{*} \\
(-1.78)\end{array}$ & & $\begin{array}{c}-0.008^{* *} \\
(-2.41)\end{array}$ & $\begin{array}{c}-0.012 * * * \\
(-2.63)\end{array}$ & $\begin{array}{c}-0.007 * * \\
(-2.17)\end{array}$ \\
\hline Age & & $\begin{array}{c}0.015^{*} \\
(1.79)\end{array}$ & $\begin{array}{l}0.005 \\
(0.49)\end{array}$ & $\begin{array}{l}0.016^{*} \\
(1.84)\end{array}$ & & $\begin{array}{l}0.016^{*} \\
(1.87)\end{array}$ & $\begin{array}{l}0.006 \\
(0.59)\end{array}$ & $\begin{array}{l}0.016^{*} \\
(1.92)\end{array}$ \\
\hline Expense & & $\begin{array}{c}-0.075^{* * *} \\
(-4.65)\end{array}$ & $\begin{array}{c}-0.101 * * * \\
(-4.53)\end{array}$ & $\begin{array}{c}-0.079 * * * \\
(-4.91)\end{array}$ & & $\begin{array}{l}-0.005 \\
(-0.28)\end{array}$ & $\begin{array}{l}-0.028 \\
(-1.25)\end{array}$ & $\begin{array}{l}-0.009 \\
(-0.55)\end{array}$ \\
\hline Turnover & & $\begin{array}{c}-0.026^{* * * *} \\
(-3.49)\end{array}$ & $\begin{array}{c}-0.035 * * * \\
(-3.21)\end{array}$ & $\begin{array}{c}-0.028 * * * \\
(-3.69)\end{array}$ & & $\begin{array}{c}-0.025 * * * \\
(-3.40)\end{array}$ & $\begin{array}{c}-0.034 * * * \\
(-3.13)\end{array}$ & $\begin{array}{c}-0.028^{* * *} \\
(-3.63)\end{array}$ \\
\hline Flow & & $\begin{array}{c}0.002 * * * \\
(2.59)\end{array}$ & $\begin{array}{l}0.011 \\
(1.08)\end{array}$ & $\begin{array}{c}0.002 * * * \\
(2.70)\end{array}$ & & $\begin{array}{c}0.002 * * * \\
(2.73)\end{array}$ & $\begin{array}{l}0.008 \\
(0.79)\end{array}$ & $\begin{array}{c}0.002^{* * *} \\
(2.81)\end{array}$ \\
\hline Alpha & & $\begin{array}{l}0.014 \\
(0.63)\end{array}$ & $\begin{array}{c}0.048^{* *} \\
(2.09)\end{array}$ & $\begin{array}{l}0.006 \\
(0.25)\end{array}$ & & $\begin{array}{l}0.011 \\
(0.46)\end{array}$ & $\begin{array}{l}0.045^{*} \\
(1.94)\end{array}$ & $\begin{array}{l}0.002 \\
(0.08)\end{array}$ \\
\hline AS & & & $\begin{array}{c}0.177^{* * *} \\
(3.89)\end{array}$ & & & & $\begin{array}{c}0.180^{* * *} \\
(3.97)\end{array}$ & \\
\hline RPI & & & $\begin{array}{l}0.061 \\
(0.49)\end{array}$ & & & & $\begin{array}{l}0.063 \\
(0.51)\end{array}$ & \\
\hline Similarity & & & $\begin{array}{c}0.087 * * * \\
(2.74)\end{array}$ & & & & $\begin{array}{c}0.087 * * * \\
(2.74)\end{array}$ & \\
\hline TE & & & & $\begin{array}{l}1.577 \\
(1.60)\end{array}$ & & & & $\begin{array}{l}1.646^{*} \\
(1.68)\end{array}$ \\
\hline Adj $R^{2}$ & 0.060 & 0.062 & 0.092 & 0.062 & 0.060 & 0.061 & 0.092 & 0.061 \\
\hline $\mathrm{N}$ & 167854 & 160067 & 81759 & 159588 & 167854 & 160067 & 81759 & 159588 \\
\hline
\end{tabular}




\section{Table V \\ Revealing Skill through Investment Choices}

This table presents average monthly returns to quintile portfolios of stocks sorted on a stock-level measure of fund herding, $\mathrm{S}^{\mathrm{FH}}$. The sample is restricted to stocks with small past institutional trades, that is, stocks in the bottom tercile of the absolute value of the change in institutional ownership $(|\Delta \mathrm{IO}|)$ experienced in quarter $t-1$. We aggregate the positions of each stock across mutual fund portfolios using weights that account for the Fund Herding (FH) of each fund, measured in quarter $t$. The portfolio weight of a given stock in a given fund is scaled by a transformation of FH whereby the decile rank of FH is demeaned, multiplied by -1 , and divided by 10 . This weighting scheme implies that large positions in the portfolio of herding funds get a large negative weight, and large positions in the portfolio of antiherding funds get a large positive weight. Based on this stock-level measure of fund herding, $\mathrm{S}^{\mathrm{FH}}$, we sort stocks into quintiles and measure their equally weighted portfolio returns in the subsequent quarter, $t+1$. The monthly return series span January 1990 to December 2009. We report average returns as well as risk-adjusted returns in monthly percentages based on the CAPM, the Fama and French (1993, FF) three-factor model, the Carhart (1997) four-factor model, and the Pastor and Stambaugh $(2003$, PS) five-factor model. Newey-West (1987) $t$-statistics are shown in parentheses. $* * *, * *$, and $*$ denote statistical significance at the $1 \%, 5 \%$, and $10 \%$ level, respectively.

\begin{tabular}{lcccccc}
\hline $\mathrm{S}^{\mathrm{FH}}$ & Low & 2 & 3 & 4 & High & High-Low \\
\hline Average & $0.93^{* *}$ & $1.07^{* * *}$ & $0.92^{* * *}$ & $1.21^{* * *}$ & $1.42^{* * *}$ & $0.49^{* * *}$ \\
& $(2.48)$ & $(3.30)$ & $(2.80)$ & $(3.56)$ & $(3.95)$ & $(3.03)$ \\
CAPM $\alpha$ & 0.08 & $0.29^{* *}$ & 0.15 & $0.42^{* *}$ & $0.62^{* * *}$ & $0.54^{* * *}$ \\
& $(0.49)$ & $(2.09)$ & $(0.91)$ & $(2.52)$ & $(3.11)$ & $(3.36)$ \\
FF $\alpha$ & -0.06 & 0.14 & -0.01 & 0.20 & $0.39^{* *}$ & $0.45^{* * *}$ \\
& $(-0.40)$ & $(1.25)$ & $(-0.05)$ & $(1.53)$ & $(2.36)$ & $(2.83)$ \\
Carhart $\alpha$ & 0.11 & $0.24^{* *}$ & 0.10 & $0.31^{* *}$ & $0.49^{* * *}$ & $0.38^{* *}$ \\
& $(0.71)$ & $(2.19)$ & $(0.65)$ & $(2.38)$ & $(3.07)$ & $(2.36)$ \\
PS $\alpha$ & -0.17 & 0.20 & -0.05 & 0.16 & 0.30 & $0.47^{* *}$ \\
& $(-0.98)$ & $(1.43)$ & $(-0.32)$ & $(1.11)$ & $(1.56)$ & $(2.43)$ \\
\hline
\end{tabular}




\section{Table VI}

\section{Fund Herding and Future Performance: Time-Varying Investment Opportunities}

This table presents results from time-series and panel regressions that estimate the relation between fund herding $(\mathrm{FH})$ and future performance conditional on the level of investment opportunities in the mutual fund industry. We consider three proxies for investment opportunities: the dispersion in stock returns, measured by the Russell-Parametric CrossSectional Volatility Index for U.S. equities from July 1996 to December 2009 (CrossVol); idiosyncratic volatility, measured by the average standard deviation of the residuals from daily Fama-French (1993) regressions of stock returns (IV); investor sentiment, from Baker and Wurgler (2006). We use both contemporaneous and lagged measures of the proxies for investment opportunities. Panel A shows time-series regressions. At the end of each quarter from 1989Q4 to 2009Q3, we sort mutual funds into 10 portfolios on the basis of Fund Herding $(F H)$ and compute their monthly equallyweighted net returns (in percent). The return series span January 1990 to December 2009. We compute the difference in returns between Decile 10, with the highest $F H$, and Decile 1, with the lowest $F H$. We then run time-series regressions of this return differential on the proxies for investment opportunities, which are standardized to have a mean of zero and a standard deviation of one. Panel B presents results from predictive panel regressions of mutual fund performance as measured by the Carhart (1997) four-factor net fund alpha (in percent) on $F H$, fund characteristics, and interaction terms between $\mathrm{FH}$ and the proxies for investment opportunities, both contemporaneous and lagged. The panel regressions control for fund size, fund age, expense ratio (in percent), fund turnover, fund percentage flows over the past quarter, and fund alpha (in percent) over the past three years. The regressions include time fixed effects and the standard errors are clustered by fund. $t$-statistics are shown in parentheses. $* * *, * *$, and $*$ denote statistical significance at the $1 \%$, $5 \%$, and $10 \%$ level, respectively.

Panel A: Time-Series Regressions

\begin{tabular}{|c|c|c|c|c|c|c|}
\hline \multicolumn{7}{|c|}{ Panel A: Time-Series Regressions } \\
\hline \multicolumn{7}{|c|}{ Dependent Variable: Net Return Differential between Herding and Antiherding Funds } \\
\hline CrossVolt $_{t}$ & $\begin{array}{c}-0.206^{* * *} \\
(-2.97)\end{array}$ & & & & & \\
\hline CrossVol $_{t-1}$ & & $\begin{array}{c}-0.221 * * * \\
(-3.19)\end{array}$ & & & & \\
\hline $\mathrm{IV}_{\mathrm{t}}$ & & & $\begin{array}{c}-0.114 * * \\
(-2.04)\end{array}$ & & & \\
\hline $\mathrm{IV}_{\mathrm{t}-1}$ & & & & $\begin{array}{c}-0.121 * * \\
(-2.18)\end{array}$ & & \\
\hline Sent $_{t}$ & & & & & $\begin{array}{c}-0.256 * * * \\
(-4.78)\end{array}$ & \\
\hline Sent $_{t-1}$ & & & & & & $\begin{array}{c}-0.243 * * * \\
(-4.50)\end{array}$ \\
\hline Intercept & $\begin{array}{c}-0.263 * * * \\
(-3.80)\end{array}$ & $\begin{array}{c}-0.261 * * * \\
(-3.77)\end{array}$ & $\begin{array}{c}-0.190 * * * \\
(-3.42)\end{array}$ & $\begin{array}{c}-0.184 * * * \\
(-3.32)\end{array}$ & $\begin{array}{c}-0.190 * * * \\
(-3.55)\end{array}$ & $\begin{array}{c}-0.190 * * * \\
(-3.53)\end{array}$ \\
\hline Adj $R^{2}$ & 0.046 & 0.054 & 0.013 & 0.015 & 0.084 & 0.075 \\
\hline $\mathrm{N}$ & 162 & 161 & 240 & 239 & 240 & 240 \\
\hline
\end{tabular}




\begin{tabular}{|c|c|c|c|c|c|c|}
\hline \multicolumn{7}{|c|}{ Panel B: Predictive Panel Regressions } \\
\hline \multicolumn{7}{|c|}{ Dependent Variable: Four-Factor Net $\alpha$} \\
\hline Fund Herding & $\begin{array}{c}-0.529 * * * \\
(-4.76)\end{array}$ & $\begin{array}{c}-0.535^{* * *} \\
(-4.92)\end{array}$ & $\begin{array}{c}-0.480 * * * \\
(-4.67)\end{array}$ & $\begin{array}{c}-0.459 * * * \\
(-4.41)\end{array}$ & $\begin{array}{c}-0.416^{* * *} \\
(-4.70)\end{array}$ & $\begin{array}{c}-0.419 * * * \\
(-4.73)\end{array}$ \\
\hline $\mathrm{FH} \times \mathrm{Cross} \mathrm{Ol}_{\mathrm{t}}$ & $\begin{array}{c}-0.322 * * \\
(-2.14)\end{array}$ & & & & & \\
\hline $\mathrm{FH} \times{\mathrm{Cross} V o l_{t-1}}$ & & $\begin{array}{c}-0.324 * * \\
(-2.51)\end{array}$ & & & & \\
\hline $\mathrm{FH} \times \mathrm{IV}_{\mathrm{t}}$ & & & $\begin{array}{l}-0.165^{*} \\
(-1.88)\end{array}$ & & & \\
\hline $\mathrm{FH} \times \mathrm{IV}_{\mathrm{t}-1}$ & & & & $\begin{array}{l}-0.102 \\
(-1.10)\end{array}$ & & \\
\hline $\mathrm{FH} \times$ Sent $_{\mathrm{t}}$ & & & & & $\begin{array}{c}-0.358^{* * * *} \\
(-2.64)\end{array}$ & \\
\hline $\mathrm{FH} \times$ Sent $_{\mathrm{t}-1}$ & & & & & & $\begin{array}{c}-0.276^{* *} \\
(-2.15)\end{array}$ \\
\hline Size & $\begin{array}{c}-0.010^{* * *} \\
(-2.76)\end{array}$ & $\begin{array}{c}-0.010^{* * *} \\
(-2.80)\end{array}$ & $\begin{array}{c}-0.007 * * \\
(-2.03)\end{array}$ & $\begin{array}{c}-0.007 * * \\
(-2.05)\end{array}$ & $\begin{array}{c}-0.007 * * \\
(-1.97)\end{array}$ & $\begin{array}{c}-0.007 * * \\
(-1.98)\end{array}$ \\
\hline Age & $\begin{array}{c}0.030^{* * *} \\
(3.39)\end{array}$ & $\begin{array}{c}0.030^{* * *} \\
(3.38)\end{array}$ & $\begin{array}{c}0.015^{*} \\
(1.81)\end{array}$ & $\begin{array}{l}0.016^{*} \\
(1.85)\end{array}$ & $\begin{array}{c}0.015^{*} \\
(1.80)\end{array}$ & $\begin{array}{l}0.015^{*} \\
(1.79)\end{array}$ \\
\hline Expense & $\begin{array}{c}-0.067 * * * \\
(-3.78)\end{array}$ & $\begin{array}{c}-0.067 * * * \\
(-3.82)\end{array}$ & $\begin{array}{c}-0.076^{* * *} \\
(-4.69)\end{array}$ & $\begin{array}{c}-0.076^{* * *} \\
(-4.68)\end{array}$ & $\begin{array}{c}-0.076^{* * *} \\
(-4.68)\end{array}$ & $\begin{array}{c}-0.076 * * * \\
(-4.68)\end{array}$ \\
\hline Turnover & $\begin{array}{c}-0.023 * * * \\
(-3.01)\end{array}$ & $\begin{array}{c}-0.023^{* * *} \\
(-3.02)\end{array}$ & $\begin{array}{c}-0.025 * * * \\
(-3.44)\end{array}$ & $\begin{array}{c}-0.025^{* * *} \\
(-3.45)\end{array}$ & $\begin{array}{c}-0.025 * * * \\
(-3.44)\end{array}$ & $\begin{array}{c}-0.025 * * * \\
(-3.45)\end{array}$ \\
\hline Flow & $\begin{array}{c}0.002 * * * \\
(3.41)\end{array}$ & $\begin{array}{c}0.002 * * * \\
(3.44)\end{array}$ & $\begin{array}{c}0.002 * * * \\
(2.61)\end{array}$ & $\begin{array}{c}0.002 * * * \\
(2.60)\end{array}$ & $\begin{array}{c}0.002 * * * \\
(2.59)\end{array}$ & $\begin{array}{c}0.002 * * * \\
(2.59)\end{array}$ \\
\hline Alpha & $\begin{array}{l}0.025 \\
(1.12)\end{array}$ & $\begin{array}{l}0.024 \\
(1.09)\end{array}$ & $\begin{array}{l}0.015 \\
(0.67)\end{array}$ & $\begin{array}{l}0.016 \\
(0.69)\end{array}$ & $\begin{array}{l}0.017 \\
(0.74)\end{array}$ & $\begin{array}{l}0.016 \\
(0.71)\end{array}$ \\
\hline Adj $R^{2}$ & 0.064 & 0.064 & 0.060 & 0.060 & 0.060 & 0.060 \\
\hline $\mathrm{N}$ & 140041 & 139837 & 160067 & 159841 & 160067 & 160067 \\
\hline
\end{tabular}




\section{Table VII}

\section{Fund Herding and Persistence in Performance}

This table presents long-term differences in performance between herding and antiherding funds. Mutual funds are sorted into 10 portfolios based on Fund Herding, as described in Table I. The return series span January 1990 to December 2009. The holding period for each portfolio, indicated by K, varies from six months to 24 months. The table reports differences in returns between Decile 10 (highest herding) and Decile 1 (lowest herding). We compute monthly equally-weighted net and gross (net plus expense ratio) returns on the portfolios, as well as risk-adjusted returns based on the CAPM, the Fama and French (1993, FF) three-factor model, the Carhart (1997) four-factor model, and the Pastor and Stambaugh (2003, PS) five-factor model. Returns and alphas are in monthly percentages. Newey-West (1987) $t$-statistics are shown in parentheses. $* * *, * *$, and $*$ denote statistical significance at the $1 \%, 5 \%$, and $10 \%$ level, respectively.

\begin{tabular}{|c|c|c|c|c|c|c|c|}
\hline & $\mathrm{K}=6$ & $\mathrm{~K}=9$ & $\mathrm{~K}=12$ & $\mathrm{~K}=15$ & $\mathrm{~K}=18$ & $\mathrm{~K}=21$ & $\mathrm{~K}=24$ \\
\hline \multicolumn{8}{|c|}{ Net Return } \\
\hline \multirow[t]{2}{*}{ Average } & $-0.15 * * *$ & $-0.15 * * *$ & $-0.15 * * *$ & $-0.13 * *$ & $-0.13 * *$ & $-0.12 *$ & $-0.10^{*}$ \\
\hline & $(-2.83)$ & $(-3.04)$ & $(-2.62)$ & $(-2.14)$ & $(-1.98)$ & $(-1.88)$ & $(-1.71)$ \\
\hline \multirow[t]{2}{*}{ CAPM $\alpha$} & $-0.17 * * *$ & $-0.17 * * *$ & $-0.17 * * *$ & $-0.15 * *$ & $-0.15^{* *}$ & $-0.13 * *$ & $-0.11 * *$ \\
\hline & $(-3.15)$ & $(-3.42)$ & $(-2.99)$ & $(-2.46)$ & $(-2.29)$ & $(-2.24)$ & $(-2.14)$ \\
\hline \multirow[t]{2}{*}{$\mathrm{FF} \alpha$} & $-0.13 * * *$ & $-0.14 * * *$ & $-0.13 * * *$ & $-0.12 * * *$ & $-0.12 * *$ & $-0.10 * *$ & $-0.09 * *$ \\
\hline & $(-3.07)$ & $(-3.59)$ & $(-3.21)$ & $(-2.60)$ & $(-2.53)$ & $(-2.56)$ & $(-2.50)$ \\
\hline \multirow[t]{2}{*}{ Carhart $\alpha$} & $-0.11 * * *$ & $-0.12 * * *$ & $-0.11 * * *$ & $-0.09 * *$ & $-0.09 * *$ & $-0.08 * *$ & $-0.06 * *$ \\
\hline & $(-2.67)$ & $(-3.41)$ & $(-3.00)$ & $(-2.38)$ & $(-2.35)$ & $(-2.43)$ & $(-2.36)$ \\
\hline \multirow[t]{2}{*}{$\mathrm{PS} \alpha$} & $-0.10 * *$ & $-0.11 * * *$ & $-0.10 * * *$ & $-0.08 * *$ & $-0.08 * *$ & $-0.06 * *$ & $-0.05^{*}$ \\
\hline & $(-2.38)$ & $(-2.98)$ & $(-2.63)$ & $(-2.04)$ & $(-2.01)$ & $(-2.02)$ & $(-1.88)$ \\
\hline \multicolumn{8}{|c|}{ Gross Return } \\
\hline \multirow[t]{2}{*}{ Average } & $-0.15 * * *$ & $-0.15 * * *$ & $-0.15 * * *$ & $-0.13 * *$ & $-0.13 * *$ & $-0.12 *$ & $-0.10^{*}$ \\
\hline & $(-2.84)$ & $(-3.04)$ & $(-2.61)$ & $(-2.13)$ & $(-1.98)$ & $(-1.88)$ & $(-1.71)$ \\
\hline \multirow[t]{2}{*}{ CAPM $\alpha$} & $-0.17 * * *$ & $-0.17 * * *$ & $-0.17 * * *$ & $-0.15^{* *}$ & $-0.15 * *$ & $-0.13 * *$ & $-0.12 * *$ \\
\hline & $(-3.17)$ & $(-3.42)$ & $(-2.98)$ & $(-2.46)$ & $(-2.29)$ & $(-2.24)$ & $(-2.14)$ \\
\hline \multirow[t]{2}{*}{ FF $\alpha$} & $-0.13 * * *$ & $-0.14 * * *$ & $-0.14 * * *$ & $-0.12 * *$ & $-0.12 * *$ & $-0.10 * *$ & $-0.09 * *$ \\
\hline & $(-3.10)$ & $(-3.60)$ & $(-3.21)$ & $(-2.59)$ & $(-2.53)$ & $(-2.56)$ & $(-2.49)$ \\
\hline \multirow[t]{2}{*}{ Carhart $\alpha$} & $-0.11 * * *$ & $-0.12 * * *$ & $-0.11 * * *$ & $-0.09 * *$ & $-0.09 * *$ & $-0.08 * *$ & $-0.07 * *$ \\
\hline & $(-2.69)$ & $(-3.41)$ & $(-3.00)$ & $(-2.38)$ & $(-2.36)$ & $(-2.44)$ & $(-2.37)$ \\
\hline \multirow[t]{2}{*}{$\mathrm{PS} \alpha$} & $-0.10 * *$ & $-0.11 * * *$ & $-0.10 * * *$ & $-0.08 * *$ & $-0.08 * *$ & $-0.06^{* *}$ & $-0.05^{*}$ \\
\hline & $(-2.40)$ & $(-2.99)$ & $(-2.63)$ & $(-2.04)$ & $(-2.01)$ & $(-2.02)$ & $(-1.88)$ \\
\hline
\end{tabular}


Table VIII

\section{Anticipating the Actions of the Crowd}

This table presents coefficients from cross-sectional predictive regressions that use the trades of herding and antiherding funds in quarter $t$ to forecast aggregate institutional trades in the subsequent quarter (quarter $t+1$ ) and in the subsequent year (quarters $t+1$ to $t+4$ ). Herding and antiherding funds are defined as the top and bottom $10 \%$ of funds based on Fund Herding measured in quarter $t-1$; Fund Herding is constructed from cross-sectional regressions of mutual fund trades on past aggregate institutional trades, as described in Table I. For each stock, we compute the change in the fraction of shares owned by herding and antiherding funds in quarter $t$ as the predictive variables, and the change in the fraction of shares owned by institutions in quarter $t+1$ (or in quarters $t+1$ to $t+4$ ) as the dependent variable. The control variables are past aggregate institutional trades (lagged $\Delta \mathrm{IO}$ ), size, book-to-market, momentum (past quarterly return) and turnover, measured in quarter $t$. The estimates are time-series averages of coefficients from Fama-MacBeth (1973) cross-sectional regressions. Newey-West (1987) $t$-statistics are shown in parentheses. $* * *, * *$, and $*$ denote statistical significance at the $1 \%, 5 \%$, and $10 \%$ level, respectively.

\begin{tabular}{|c|c|c|c|c|c|c|c|c|}
\hline \multirow[b]{2}{*}{ Trades of Antiherding Funds } & \multicolumn{4}{|c|}{ Dependent Variable: $\Delta \mathrm{IO}(t+1)$} & \multicolumn{4}{|c|}{ Dependent Variable: $\Delta \mathrm{IO}(t+1: t+4)$} \\
\hline & $1.120 * *$ & & $1.297 * *$ & $1.140 * *$ & $1.747^{*}$ & & $2.257 * *$ & $2.420 * *$ \\
\hline & $(2.07)$ & & $(2.38)$ & $(2.15)$ & $(1.83)$ & & $(2.54)$ & $(2.38)$ \\
\hline \multirow[t]{2}{*}{ Trades of Herding Funds } & & 0.177 & 0.033 & 0.068 & & -0.565 & -0.899 & -0.655 \\
\hline & & $(0.39)$ & $(0.07)$ & $(0.17)$ & & $(-0.71)$ & $(-1.12)$ & $(-0.83)$ \\
\hline \multirow[t]{2}{*}{ Lagged $\Delta \mathrm{IO}$} & & & & $-0.300 * * *$ & & & & $-0.289 * * *$ \\
\hline & & & & $(-11.95)$ & & & & $(-9.13)$ \\
\hline \multirow[t]{2}{*}{ Size } & & & & $-0.001 * *$ & & & & $0.002 *$ \\
\hline & & & & $(-1.97)$ & & & & $(1.66)$ \\
\hline \multirow[t]{2}{*}{$\mathrm{BM}$} & & & & -0.001 & & & & -0.002 \\
\hline & & & & $(-0.56)$ & & & & $(-1.04)$ \\
\hline \multirow[t]{2}{*}{ Momentum } & & & & 0.008 & & & & -0.019 \\
\hline & & & & $(1.07)$ & & & & $(-1.56)$ \\
\hline \multirow[t]{2}{*}{ Turnover } & & & & $-0.044 * * *$ & & & & $-0.102 * * *$ \\
\hline & & & & $(-5.56)$ & & & & $(-7.71)$ \\
\hline $\operatorname{Adj} R^{2}$ & 0.003 & 0.007 & 0.009 & 0.143 & 0.005 & 0.01 & 0.014 & 0.077 \\
\hline $\mathrm{N}$ & 19095 & 19095 & 19095 & 19095 & 18814 & 18814 & 18814 & 18814 \\
\hline
\end{tabular}




\section{Table IX}

\section{Termination Probabilities}

This table presents estimated coefficients and marginal effects from logit regressions of the probability of termination for a mutual fund manager on a set of characteristics. The sample includes only funds managed by an individual manager and spans January 1990 to December 2009. Termination is an indicator for whether the manager of a given fund in quarter $t$ is no longer in our sample from quarter $t+1$ onward. The regressors are described in Table III. All variables are standardized to have a mean of zero and a standard deviation of one in each quarter. Marginal effects, shown in brackets, are calculated for an infinitesimal increase in a given variable holding all other variables at their mean values. $z$-statistics are shown in parentheses. $* * *, * *$, and $*$ denote statistical significance at the $1 \%, 5 \%$, and $10 \%$ level, respectively.

\begin{tabular}{|c|c|c|c|c|}
\hline \multicolumn{5}{|c|}{ Panel A: Whole Sample } \\
\hline \multirow[t]{3}{*}{ Fund Herding } & $-0.075 * *$ & $-0.080 * * *$ & $-0.074 * *$ & $-0.079 * * *$ \\
\hline & $(-2.49)$ & $(-2.61)$ & $(-2.46)$ & $(-2.58)$ \\
\hline & {$[-0.0035]$} & {$[-0.0037]$} & {$[-0.0034]$} & {$[-0.0037]$} \\
\hline \multirow[t]{3}{*}{ Experience } & $-0.183 * * *$ & $-0.187 * * *$ & & \\
\hline & $(-5.51)$ & $(-5.57)$ & & \\
\hline & {$[-0.0081]$} & {$[-0.0086]$} & & \\
\hline \multirow[t]{3}{*}{ Tenure } & & & $-0.144 * * *$ & $-0.145^{* * *}$ \\
\hline & & & $(-4.41)$ & $(-4.41)$ \\
\hline & & & {$[-0.0066]$} & {$[-0.0067]$} \\
\hline \multirow[t]{3}{*}{ TNA } & $-0.209 * * *$ & $-0.203 * * *$ & $-0.225 * * *$ & $-0.219 * * *$ \\
\hline & $(-5.67)$ & $(-5.50)$ & $(-6.18)$ & $(-6.01)$ \\
\hline & {$[-0.0090]$} & {$[-0.0094]$} & {$[-0.0104]$} & {$[-0.0102]$} \\
\hline \multirow[t]{3}{*}{ Age } & $0.110 * * *$ & $0.113 * * *$ & $0.109 * * *$ & $0.111 * * *$ \\
\hline & $(3.16)$ & $(3.22)$ & (3.08) & (3.14) \\
\hline & {$[0.0037]$} & {$[0.0052]$} & {$[0.0050]$} & {$[0.0051]$} \\
\hline \multirow[t]{3}{*}{ Expense } & 0.009 & 0.020 & 0.011 & 0.021 \\
\hline & $(0.30)$ & $(0.65)$ & $(0.38)$ & $(0.71)$ \\
\hline & [0.0003] & {$[0.0009]$} & {$[0.0005]$} & {$[0.0010]$} \\
\hline \multirow[t]{3}{*}{ Turnover } & 0.020 & 0.033 & 0.016 & 0.029 \\
\hline & $(0.68)$ & $(1.12)$ & $(0.56)$ & $(0.99)$ \\
\hline & {$[0.0008]$} & {$[0.0015]$} & {$[0.0008]$} & [0.0014] \\
\hline \multirow[t]{3}{*}{ Flow } & -0.077 & -0.075 & -0.076 & -0.075 \\
\hline & $(-1.20)$ & $(-1.18)$ & $(-1.20)$ & $(-1.18)$ \\
\hline & {$[-0.0037]$} & {$[-0.0035]$} & {$[-0.0035]$} & {$[-0.0035]$} \\
\hline \multirow[t]{3}{*}{ Alpha } & $-0.161 * * *$ & $-0.163 * * *$ & $-0.156^{* * *}$ & $-0.159 * * *$ \\
\hline & $(-5.56)$ & $(-5.58)$ & $(-5.39)$ & $(-5.42)$ \\
\hline & {$[-0.0075]$} & {$[-0.0075]$} & {$[-0.0072]$} & {$[-0.0074]$} \\
\hline \multirow[t]{3}{*}{$\mathrm{TE}$} & & $-0.054^{*}$ & & $-0.052^{*}$ \\
\hline & & $(-1.78)$ & & $(-1.70)$ \\
\hline & & {$[-0.0025]$} & & {$[-0.0024]$} \\
\hline Adj $R^{2}$ & 0.129 & 0.128 & 0.127 & 0.126 \\
\hline $\mathrm{N}$ & 17593 & 17417 & 17593 & 17387 \\
\hline
\end{tabular}




\begin{tabular}{|c|c|c|c|c|c|c|c|c|}
\hline \multicolumn{9}{|c|}{ Panel B: Sample Split by Experience or Tenure } \\
\hline & \multicolumn{4}{|c|}{ Experience } & \multicolumn{4}{|c|}{ Tenure } \\
\hline & \multicolumn{2}{|c|}{ Low } & \multicolumn{2}{|c|}{ High } & \multicolumn{2}{|c|}{ Low } & \multicolumn{2}{|c|}{ High } \\
\hline \multirow[t]{3}{*}{ FH } & $-0.106^{* * *}$ & $-0.106^{* * *}$ & -0.028 & -0.041 & $-0.105^{* * *}$ & $-0.104 * * *$ & -0.049 & -0.061 \\
\hline & $(-2.92)$ & $(-2.89)$ & $(-0.56)$ & $(-0.78)$ & $(-2.65)$ & $(-2.61)$ & $(-1.03)$ & $(-1.25)$ \\
\hline & {$[-0.0062]$} & {$[-0.0061]$} & {$[-0.0011]$} & {$[-0.0017]$} & {$[-0.0057]$} & {$[-0.0056]$} & {$[-0.0022]$} & {$[-0.0028]$} \\
\hline \multirow[t]{3}{*}{ Experience } & $-0.230^{* *}$ & $-0.239 * *$ & $-0.122 * *$ & $-0.119 * *$ & & & & \\
\hline & $(-2.08)$ & $(-2.14)$ & $(-2.07)$ & $(-1.99)$ & & & & \\
\hline & {$[-0.0133]$} & {$[-0.0138]$} & {$[-0.0049]$} & {$[-0.0048]$} & & & & \\
\hline \multirow[t]{3}{*}{ Tenure } & & & & & 0.130 & 0.127 & $-0.159 * * *$ & $-0.147^{* *}$ \\
\hline & & & & & $(0.93)$ & $(0.90)$ & $(-2.78)$ & $(-2.54)$ \\
\hline & & & & & {$[0.0071]$} & {$[0.0069]$} & {$[-0.0071]$} & {$[-0.0067]$} \\
\hline \multirow[t]{3}{*}{ TNA } & $-0.177 * * *$ & $-0.173^{* * *}$ & $-0.241 * * *$ & $-0.235^{* * *}$ & $-0.303^{* * *}$ & $-0.305^{* * *}$ & $-0.170^{* * *}$ & $-0.156^{* * *}$ \\
\hline & $(-3.57)$ & $(-3.47)$ & $(-4.29)$ & $(-4.20)$ & $(-5.98)$ & $(-6.03)$ & $(-3.35)$ & $(-3.09)$ \\
\hline & {$[-0.0102]$} & {$[-0.0100]$} & {$[-0.0097]$} & {$[-0.0096]$} & {$[-0.0164]$} & {$[-0.0165]$} & {$[-0.0076]$} & {$[-0.0071]$} \\
\hline \multirow[t]{3}{*}{ Age } & $0.125^{* * *}$ & $0.129 * * *$ & 0.077 & 0.071 & $0.164 * * *$ & $0.166^{* * *}$ & 0.090 & 0.085 \\
\hline & $(2.87)$ & (2.94) & $(1.33)$ & $(1.21)$ & (3.49) & $(3.54)$ & $(1.52)$ & $(1.43)$ \\
\hline & {$[0.0072]$} & {$[0.0074]$} & [0.0031] & [0.0029] & {$[0.0089]$} & {$[0.0090]$} & [0.0040] & [0.0039] \\
\hline \multirow[t]{3}{*}{ Expense } & 0.064 & 0.062 & -0.054 & -0.021 & 0.056 & 0.051 & -0.034 & -0.006 \\
\hline & (1.59) & $(1.50)$ & $(-1.23)$ & $(-0.47)$ & $(1.32)$ & $(1.17)$ & $(-0.83)$ & $(-0.14)$ \\
\hline & {$[0.0037]$} & {$[0.0036]$} & {$[-0.0022]$} & {$[-0.0008]$} & {$[0.0030]$} & {$[0.0028]$} & {$[-0.0015]$} & {$[-0.0003]$} \\
\hline \multirow[t]{3}{*}{ Turnover } & -0.012 & -0.011 & $0.080^{*}$ & $0.118^{* *}$ & -0.037 & -0.036 & $0.118^{* *}$ & $0.153^{* * *}$ \\
\hline & $(-0.34)$ & $(-0.31)$ & $(1.67)$ & $(2.42)$ & $(-0.97)$ & $(-0.94)$ & $(2.33)$ & $(2.96)$ \\
\hline & {$[-0.0007]$} & {$[-0.0007]$} & {$[0.0032]$} & {$[0.0048]$} & {$[-0.0020]$} & {$[-0.0020]$} & [0.0053] & {$[0.0070]$} \\
\hline \multirow[t]{3}{*}{ Flow } & -0.014 & -0.013 & $-0.302 * * *$ & $-0.307 * * *$ & -0.034 & -0.034 & $-0.181^{*}$ & $-0.179^{*}$ \\
\hline & $(-0.23)$ & $(-0.23)$ & $(-2.76)$ & $(-2.75)$ & $(-0.47)$ & $(-0.47)$ & $(-1.92)$ & $(-1.87)$ \\
\hline & {$[-0.0008]$} & {$[-0.0008]$} & {$[-0.0121]$} & {$[-0.0125]$} & {$[-0.0019]$} & {$[-0.0019]$} & {$[-0.0081]$} & {$[-0.0081]$} \\
\hline \multirow[t]{3}{*}{ Alpha } & $-0.192 * * *$ & $-0.194^{* * *}$ & $-0.094^{*}$ & $-0.092 *$ & $-0.167 * * *$ & $-0.168^{* * *}$ & $-0.137 * * *$ & $-0.139 * * *$ \\
\hline & $(-5.53)$ & $(-5.56)$ & $(-1.86)$ & $(-1.74)$ & $(-4.42)$ & $(-4.43)$ & $(-2.90)$ & $(-2.82)$ \\
\hline & {$[-0.0111]$} & {$[-0.0112]$} & {$[-0.0038]$} & {$[-0.0038]$} & {$[-0.0090]$} & {$[-0.0091]$} & {$[-0.0061]$} & {$[-0.0063]$} \\
\hline \multirow[t]{3}{*}{$\mathrm{TE}$} & & -0.006 & & $-0.141 * * *$ & & 0.000 & & $-0.109^{* *}$ \\
\hline & & $(-0.15)$ & & $(-2.94)$ & & $(-0.01)$ & & $(-2.43)$ \\
\hline & & {$[-0.0004]$} & & {$[-0.0058]$} & & {$[0.0000]$} & & {$[-0.0050]$} \\
\hline Adj $R^{2}$ & 0.125 & 0.124 & 0.128 & 0.128 & 0.132 & 0.132 & 0.117 & 0.117 \\
\hline $\mathrm{N}$ & 8583 & 8543 & 8251 & 8095 & 7927 & 7897 & 8887 & 8719 \\
\hline
\end{tabular}




\section{Table X}

\section{Fund Herding and Managerial Experience}

This table shows the estimated coefficients from Fama-MacBeth (1973) quarterly regressions of Fund Herding on fund characteristics and two measures of managerial experience. The sample includes only funds managed by an individual manager. Fund Herding is constructed from cross-sectional regressions of mutual fund trades on past aggregate institutional trades, as described in Table I. Experience is the number of years in which a manager appears in the CRSP mutual fund data set; Tenure is fund-specific experience, measured as the number of years a manager is with a given fund. The control variables are described in Table III. The regressors are standardized to have a mean of zero and a standard deviation of one in each quarter. Newey-West (1987) $t$-statistics are shown in parentheses. ***, **, and * denote statistical significance at the $1 \%, 5 \%$, and $10 \%$ level, respectively.

\begin{tabular}{|c|c|c|c|c|c|c|}
\hline \multirow[b]{3}{*}{ Experience } & \multicolumn{5}{|c|}{ Dependent variable: Fund Herding } & \\
\hline & & Experience & & & Tenure & \\
\hline & $\begin{array}{c}-0.144^{* *} \\
(-2.29)\end{array}$ & $\begin{array}{c}-0.160^{* *} \\
(-2.23)\end{array}$ & $\begin{array}{c}-0.148^{* *} \\
(-2.21)\end{array}$ & & & \\
\hline Tenure & & & & $\begin{array}{c}-0.158 * * \\
(-2.43)\end{array}$ & $\begin{array}{c}-0.135^{*} \\
(-1.78)\end{array}$ & $\begin{array}{c}-0.163 * * \\
(-2.22)\end{array}$ \\
\hline Size & $\begin{array}{c}-0.188^{* * *} \\
(-2.94)\end{array}$ & $\begin{array}{c}-0.15 \\
(-1.47)\end{array}$ & $\begin{array}{c}-0.172 * * * \\
(-2.70)\end{array}$ & $\begin{array}{c}-0.200 * * * \\
(-2.98)\end{array}$ & $\begin{array}{l}-0.152 \\
(-1.52)\end{array}$ & $\begin{array}{c}-0.186^{* * *} \\
(-2.84)\end{array}$ \\
\hline Age & $\begin{array}{c}0.223 * * \\
(2.36)\end{array}$ & $\begin{array}{c}0.259 * * * \\
(3.42)\end{array}$ & $\begin{array}{c}0.204 * * \\
(2.26)\end{array}$ & $\begin{array}{c}0.232^{* *} \\
(2.54)\end{array}$ & $\begin{array}{c}0.270^{* * *} \\
(3.85)\end{array}$ & $\begin{array}{c}0.214^{* *} \\
(2.43)\end{array}$ \\
\hline Expense & $\begin{array}{l}-0.115 \\
(-1.42)\end{array}$ & $\begin{array}{l}-0.152 \\
(-1.37)\end{array}$ & $\begin{array}{l}-0.072 \\
(-1.01)\end{array}$ & $\begin{array}{l}-0.127 \\
(-1.50)\end{array}$ & $\begin{array}{l}-0.159 \\
(-1.41)\end{array}$ & $\begin{array}{l}-0.084 \\
(-1.15)\end{array}$ \\
\hline Turnover & $\begin{array}{l}-0.172 \\
(-1.61)\end{array}$ & $\begin{array}{l}-0.222 \\
(-1.57)\end{array}$ & $\begin{array}{l}-0.140 \\
(-1.40)\end{array}$ & $\begin{array}{l}-0.179^{*} \\
(-1.66)\end{array}$ & $\begin{array}{l}-0.217 \\
(-1.56)\end{array}$ & $\begin{array}{l}-0.149 \\
(-1.46)\end{array}$ \\
\hline Flow & $\begin{array}{l}0.084 \\
(0.99)\end{array}$ & $\begin{array}{l}-0.030 \\
(-0.21)\end{array}$ & $\begin{array}{l}0.035 \\
(0.42)\end{array}$ & $\begin{array}{l}0.080 \\
(0.97)\end{array}$ & $\begin{array}{l}-0.040 \\
(-0.28)\end{array}$ & $\begin{array}{l}0.030 \\
(0.37)\end{array}$ \\
\hline Alpha & $\begin{array}{l}0.159 \\
(1.01)\end{array}$ & $\begin{array}{l}0.143 \\
(0.73)\end{array}$ & $\begin{array}{l}0.177 \\
(1.12)\end{array}$ & $\begin{array}{l}0.162 \\
(1.04)\end{array}$ & $\begin{array}{l}0.145 \\
(0.77)\end{array}$ & $\begin{array}{l}0.180 \\
(1.14)\end{array}$ \\
\hline AS & & $\begin{array}{c}-0.411 * * * \\
(-4.11)\end{array}$ & & & $\begin{array}{c}-0.405 * * * \\
(-3.72)\end{array}$ & \\
\hline RPI & & $\begin{array}{c}0.546^{* * *} \\
(7.67)\end{array}$ & & & $\begin{array}{c}0.559^{* * *} \\
(7.51)\end{array}$ & \\
\hline Similarity & & $\begin{array}{l}-0.137 \\
(-1.42)\end{array}$ & & & $\begin{array}{l}-0.136 \\
(-1.46)\end{array}$ & \\
\hline TE & & & $\begin{array}{l}-0.199 \\
(-1.59)\end{array}$ & & & $\begin{array}{l}-0.193 \\
(-1.49)\end{array}$ \\
\hline Adj $R^{2}$ & 0.009 & 0.026 & 0.013 & 0.009 & 0.026 & 0.013 \\
\hline $\mathrm{N}$ & 22389 & 12227 & 22325 & 22343 & 12227 & 22279 \\
\hline
\end{tabular}


Table XI

\section{Fund Herding, Managerial Experience, and Future Performance}

This table presents the monthly performance of portfolios of mutual funds double-sorted on the basis of fund herding (FH) and managerial experience. Fund Herding is constructed from cross-sectional regressions of mutual fund trades on past aggregate institutional trades, as described in Table I. We sort funds independently into four groups based on fund herding and into three groups based on one of two proxies for managerial experience: general experience or fundspecific tenure. The sample includes only funds managed by an individual manager. We compute the average monthly net return and the Carhart (1997) four-factor $\alpha$ for each of the 16 portfolios. Newey-West (1987) $t$-statistics are shown in parentheses. ***, **, and * denote statistical significance at the $1 \%, 5 \%$, and $10 \%$ level, respectively, for the return differentials between portfolios of high and low $\mathrm{FH}$.

\begin{tabular}{|c|c|c|c|c|c|c|c|c|c|c|}
\hline \multicolumn{11}{|c|}{ Panel A: General Experience } \\
\hline \multirow[b]{2}{*}{ FH } & \multicolumn{5}{|c|}{ Net Return } & \multicolumn{5}{|c|}{ Four-Factor Net $\alpha$} \\
\hline & Low & 2 & 3 & High & High-Low & Low & 2 & 3 & High & High-Low \\
\hline \multicolumn{11}{|l|}{ Experience } \\
\hline \multirow[t]{2}{*}{ Low } & 0.80 & 0.75 & 0.77 & 0.64 & $-0.16^{* *}$ & 0.02 & -0.06 & -0.02 & -0.16 & $-0.18 * *$ \\
\hline & $(2.46)$ & $(2.27)$ & $(2.35)$ & $(1.92)$ & $(-2.41)$ & $(0.21)$ & $(-0.89)$ & $(-0.23)$ & $(-2.29)$ & $(-2.60)$ \\
\hline \multirow[t]{2}{*}{ Med } & 0.79 & 0.73 & 0.71 & 0.65 & $-0.14 * *$ & 0.00 & -0.07 & -0.05 & -0.11 & $-0.11^{*}$ \\
\hline & $(2.50)$ & $(2.28)$ & $(2.16)$ & $(1.96)$ & $(-2.27)$ & $(-0.02)$ & $(-1.02)$ & $(-0.70)$ & $(-1.31)$ & $(-1.90)$ \\
\hline \multirow[t]{2}{*}{ High } & 0.78 & 0.73 & 0.68 & 0.66 & -0.12 & -0.01 & -0.06 & -0.08 & -0.12 & -0.10 \\
\hline & $(2.53)$ & $(2.42)$ & (2.12) & $(2.03)$ & $(-1.47)$ & $(-0.15)$ & $(-0.90)$ & $(-1.00)$ & $(-1.50)$ & $(-1.37)$ \\
\hline \multirow[t]{3}{*}{ High-Low } & -0.02 & -0.02 & -0.10 & 0.02 & 0.05 & -0.03 & 0.00 & -0.06 & 0.05 & 0.08 \\
\hline & $(-0.36)$ & $(-0.32)$ & $(-1.31)$ & $(0.37)$ & $(0.53)$ & $(-0.47)$ & $(-0.02)$ & $(-0.86)$ & $(0.72)$ & $(0.83)$ \\
\hline & \multicolumn{5}{|c|}{ Gross Return } & \multicolumn{5}{|c|}{ Four-Factor Gross $\alpha$} \\
\hline FH & Low & 2 & 3 & High & High-Low & Low & 2 & 3 & High & High-Low \\
\hline \multicolumn{11}{|l|}{ Experience } \\
\hline \multirow[t]{2}{*}{ Low } & 0.91 & 0.85 & 0.88 & 0.75 & $-0.17 * *$ & 0.13 & 0.05 & 0.09 & -0.05 & $-0.18 * * *$ \\
\hline & $(2.79)$ & $(2.58)$ & $(2.68)$ & $(2.25)$ & $(-2.43)$ & $(1.63)$ & $(0.76)$ & $(1.27)$ & $(-0.76)$ & $(-2.62)$ \\
\hline \multirow[t]{2}{*}{ Med } & 0.91 & 0.84 & 0.82 & 0.76 & $-0.15^{* *}$ & 0.11 & 0.03 & 0.06 & 0.00 & $-0.11 * *$ \\
\hline & $(2.85)$ & $(2.62)$ & $(2.48)$ & $(2.29)$ & $(-2.32)$ & $(1.45)$ & $(0.46)$ & $(0.86)$ & $(-0.02)$ & $(-1.96)$ \\
\hline \multirow[t]{2}{*}{ High } & 0.88 & 0.83 & 0.77 & 0.77 & -0.11 & 0.09 & 0.04 & 0.02 & -0.01 & -0.10 \\
\hline & $(2.86)$ & $(2.75)$ & $(2.43)$ & $(2.35)$ & $(-1.45)$ & $(1.12)$ & $(0.67)$ & $(0.26)$ & $(-0.13)$ & $(-1.35)$ \\
\hline \multirow[t]{2}{*}{ High-Low } & -0.03 & -0.03 & -0.10 & 0.02 & 0.05 & -0.03 & -0.01 & -0.07 & 0.04 & 0.08 \\
\hline & $(-0.46)$ & $(-0.38)$ & $(-1.43)$ & $(0.33)$ & $(0.56)$ & $(-0.57)$ & $(-0.09)$ & $(-0.98)$ & $(0.68)$ & $(0.87)$ \\
\hline
\end{tabular}




\begin{tabular}{|c|c|c|c|c|c|c|c|c|c|c|}
\hline \multicolumn{11}{|c|}{ Panel B: Fund-Specific Tenure } \\
\hline \multirow[b]{2}{*}{$\mathrm{FH}$} & \multicolumn{5}{|c|}{ Net Return } & \multicolumn{5}{|c|}{ Four-Factor Net $\alpha$} \\
\hline & Low & 2 & 3 & High & High-Low & Low & 2 & 3 & High & High-Low \\
\hline \multicolumn{11}{|l|}{ Tenure } \\
\hline \multirow{2}{*}{ Low } & 0.81 & 0.73 & 0.70 & 0.58 & $-0.23 * * *$ & 0.02 & -0.09 & -0.07 & -0.20 & $-0.22 * * *$ \\
\hline & $(2.46)$ & $(2.18)$ & $(2.13)$ & $(1.71)$ & $(-3.00)$ & $(0.19)$ & $(-1.31)$ & $(-0.95)$ & $(-2.49)$ & $(-2.93)$ \\
\hline \multirow[t]{2}{*}{ Med } & 0.79 & 0.78 & 0.74 & 0.67 & $-0.12 * *$ & 0.01 & -0.01 & -0.04 & -0.11 & $-0.12 * *$ \\
\hline & $(2.52)$ & $(2.48)$ & $(2.28)$ & $(2.06)$ & $(-2.07)$ & $(0.08)$ & $(-0.17)$ & $(-0.60)$ & $(-1.50)$ & $(-2.03)$ \\
\hline \multirow[t]{2}{*}{ High } & 0.78 & 0.70 & 0.72 & 0.71 & -0.07 & -0.02 & -0.08 & -0.03 & -0.06 & -0.04 \\
\hline & $(2.50)$ & $(2.32)$ & $(2.26)$ & $(2.19)$ & $(-0.95)$ & $(-0.20)$ & $(-1.29)$ & $(-0.41)$ & $(-0.77)$ & $(-0.62)$ \\
\hline \multirow[t]{3}{*}{ High-Low } & -0.03 & -0.03 & 0.02 & $0.13 *$ & $0.16^{*}$ & -0.03 & 0.01 & 0.04 & $0.14 * *$ & $0.17 * *$ \\
\hline & $(-0.44)$ & $(-0.40)$ & $(0.26)$ & $(1.88)$ & $(1.73)$ & $(-0.53)$ & $(0.16)$ & $(0.58)$ & $(2.34)$ & $(2.02)$ \\
\hline & \multicolumn{5}{|c|}{ Gross Return } & \multicolumn{5}{|c|}{ Four-Factor Gross $\alpha$} \\
\hline $\mathrm{FH}$ & Low & 2 & 3 & High & High-Low & Low & 2 & 3 & High & High-Low \\
\hline \multicolumn{11}{|l|}{ Tenure } \\
\hline \multirow[t]{2}{*}{ Low } & 0.91 & 0.84 & 0.81 & 0.69 & $-0.23 * * *$ & 0.12 & 0.01 & 0.04 & -0.09 & $-0.22 * * *$ \\
\hline & $(2.79)$ & $(2.48)$ & $(2.45)$ & $(2.03)$ & $(-3.00)$ & $(1.47)$ & $(0.16)$ & $(0.54)$ & $(-1.15)$ & $(-2.94)$ \\
\hline \multirow[t]{2}{*}{ Med } & 0.91 & 0.88 & 0.84 & 0.78 & $-0.12 * *$ & 0.12 & 0.10 & 0.07 & -0.01 & $-0.12 * *$ \\
\hline & $(2.88)$ & $(2.82)$ & $(2.60)$ & $(2.39)$ & $(-2.15)$ & $(1.64)$ & $(1.50)$ & $(0.96)$ & $(-0.07)$ & $(-2.10)$ \\
\hline \multirow[t]{2}{*}{ High } & 0.88 & 0.80 & 0.82 & 0.81 & -0.07 & 0.09 & 0.02 & 0.07 & 0.05 & -0.04 \\
\hline & $(2.84)$ & $(2.65)$ & $(2.56)$ & $(2.52)$ & $(-0.93)$ & $(1.14)$ & $(0.31)$ & $(0.95)$ & $(0.66)$ & $(-0.60)$ \\
\hline \multirow[t]{2}{*}{ High-Low } & -0.03 & -0.04 & 0.01 & $0.13^{*}$ & $0.16^{*}$ & -0.04 & 0.01 & 0.03 & $0.14 * *$ & $0.18 * *$ \\
\hline & $(-0.51)$ & $(-0.43)$ & $(0.17)$ & $(1.85)$ & (1.76) & $(-0.59)$ & $(0.12)$ & $(0.49)$ & $(2.31)$ & $(2.05)$ \\
\hline
\end{tabular}




\section{Table XII}

\section{Alternative Measures of Fund Herding: Controlling for Multiple Stock Characteristics}

This table presents the monthly performance of decile portfolios of funds sorted on an alternative measure of Fund Herding $(F H)$. FH is constructed from the slope coefficients of cross-sectional regressions of mutual fund trades on past orthogonalized institutional trades measured in the previous quarter; institutional trades are orthogonalized in cross-sectional regressions with respect to past stock returns, firm size, book-to-market, turnover, idiosyncratic volatility, analyst earnings forecast revisions, firm share issuance, bid-ask spread, Amihud illiquidity, and 10 industry dummies. The construction of the portfolios and the estimation of returns are described in Table II. Newey-West (1987) $t$-statistics are shown in parentheses. ${ }^{* * *}, * *$, and $*$ denote statistical significance at the $1 \%, 5 \%$, and $10 \%$ level, respectively, for the return differentials between deciles 10 and 1.

\begin{tabular}{|c|c|c|c|c|c|c|c|c|c|c|c|}
\hline FH rank & 1 & 2 & 3 & 4 & 5 & 6 & 7 & 8 & 9 & 10 & D10-D1 \\
\hline \multicolumn{12}{|c|}{ Net Return } \\
\hline \multirow[t]{2}{*}{ Average } & 0.83 & 0.79 & 0.79 & 0.78 & 0.77 & 0.76 & 0.78 & 0.73 & 0.75 & 0.68 & $-0.16 * * *$ \\
\hline & $(2.89)$ & $(2.78)$ & $(2.74)$ & $(2.73)$ & $(2.64)$ & $(2.61)$ & $(2.61)$ & $(2.45)$ & $(2.48)$ & $(2.25)$ & $(-2.69)$ \\
\hline \multirow[t]{2}{*}{$\mathrm{CAPM} \alpha$} & 0.07 & 0.03 & 0.03 & 0.02 & 0.00 & -0.01 & 0.00 & -0.05 & -0.04 & -0.11 & $-0.18 * * *$ \\
\hline & (1.03) & $(0.53)$ & $(0.43)$ & $(0.32)$ & $(-0.03)$ & $(-0.16)$ & $(-0.04)$ & $(-0.85)$ & $(-0.60)$ & $(-1.63)$ & $(-2.99)$ \\
\hline \multirow[t]{2}{*}{ FF $\alpha$} & 0.01 & -0.03 & -0.03 & -0.05 & -0.05 & -0.06 & -0.05 & -0.09 & -0.05 & -0.13 & $-0.14 * *$ \\
\hline & $(0.15)$ & $(-0.66)$ & $(-0.64)$ & $(-0.93)$ & $(-1.11)$ & $(-1.3)$ & $(-0.98)$ & $(-1.72)$ & $(-0.95)$ & $(-2.19)$ & $(-2.42)$ \\
\hline \multirow[t]{2}{*}{ Carhart $\alpha$} & 0.02 & -0.02 & -0.04 & -0.04 & -0.04 & -0.06 & -0.06 & -0.08 & -0.06 & -0.13 & $-0.15^{* *}$ \\
\hline & $(0.26)$ & $(-0.39)$ & $(-0.74)$ & $(-0.71)$ & $(-0.77)$ & $(-1.18)$ & $(-1.19)$ & $(-1.5)$ & $(-1.11)$ & $(-1.99)$ & $(-2.44)$ \\
\hline \multirow[t]{2}{*}{ PS $\alpha$} & -0.01 & -0.05 & -0.05 & -0.05 & -0.05 & -0.06 & -0.08 & -0.09 & -0.06 & -0.13 & $-0.12 * *$ \\
\hline & $(-0.24)$ & $(-0.86)$ & $(-1.10)$ & $(-1.05)$ & $(-1.06)$ & $(-1.15)$ & $(-1.49)$ & $(-1.74)$ & $(-1.11)$ & $(-1.93)$ & $(-2.01)$ \\
\hline \multicolumn{12}{|c|}{ Gross Return } \\
\hline \multirow[t]{2}{*}{ Average } & 0.94 & 0.89 & 0.89 & 0.88 & 0.86 & 0.86 & 0.87 & 0.83 & 0.86 & 0.78 & $-0.16^{* * *}$ \\
\hline & $(3.26)$ & $(3.15)$ & (3.09) & $(3.08)$ & $(2.98)$ & $(2.94)$ & $(2.95)$ & $(2.79)$ & $(2.82)$ & $(2.60)$ & $(-2.73)$ \\
\hline \multirow[t]{2}{*}{$\mathrm{CAPM} \alpha$} & 0.18 & 0.14 & 0.12 & 0.12 & 0.10 & 0.09 & 0.10 & 0.05 & 0.07 & 0.00 & $-0.18 * * *$ \\
\hline & $(2.61)$ & $(2.22)$ & $(2.10)$ & (1.94) & $(1.62)$ & $(1.45)$ & $(1.56)$ & $(0.84)$ & $(1.14)$ & $(0.01)$ & $(-3.04)$ \\
\hline \multirow[t]{2}{*}{$\mathrm{FF} \alpha$} & 0.12 & 0.07 & 0.07 & 0.05 & 0.04 & 0.03 & 0.05 & 0.01 & 0.05 & -0.02 & $-0.14 * *$ \\
\hline & $(2.07)$ & $(1.32)$ & $(1.51)$ & $(1.02)$ & $(0.86)$ & $(0.72)$ & $(1.06)$ & $(0.29)$ & $(0.91)$ & $(-0.4)$ & $(-2.47)$ \\
\hline \multirow[t]{2}{*}{ Carhart $\alpha$} & 0.12 & 0.08 & 0.06 & 0.06 & 0.06 & 0.04 & 0.04 & 0.02 & 0.04 & -0.02 & $-0.15 * *$ \\
\hline & $(2.06)$ & $(1.52)$ & $(1.29)$ & $(1.18)$ & $(1.13)$ & $(0.74)$ & $(0.76)$ & $(0.37)$ & $(0.74)$ & $(-0.37)$ & $(-2.48)$ \\
\hline \multirow[t]{2}{*}{$\operatorname{PS} \alpha$} & 0.10 & 0.06 & 0.05 & 0.04 & 0.04 & 0.04 & 0.02 & 0.01 & 0.04 & -0.02 & $-0.12 * *$ \\
\hline & $(1.70)$ & $(1.07)$ & $(0.94)$ & $(0.87)$ & $(0.81)$ & $(0.69)$ & $(0.41)$ & $(0.13)$ & $(0.71)$ & $(-0.34)$ & $(-2.05)$ \\
\hline
\end{tabular}




\section{Table XIII}

\section{Alternative Measures of Fund Herding: Controlling for Past Own Trades}

This table presents the monthly performance of decile portfolios of funds sorted on an alternative measure of Fund Herding ( FH). FH is constructed from the slope coefficients of cross-sectional regressions of mutual fund trades on past institutional trades measured in the previous quarter; the regressions control for past stock returns, firm size, book-to-market, and the fund's own trades in the previous quarter. The construction of the portfolios and the estimation of returns are described in Table II. Newey-West (1987) $t$-statistics are shown in parentheses. $* * *, * *$, and $*$ denote statistical significance at the $1 \%, 5 \%$, and $10 \%$ level, respectively, for the return differentials between deciles 10 and 1 .

\begin{tabular}{|c|c|c|c|c|c|c|c|c|c|c|c|}
\hline FH rank & 1 & 2 & 3 & 4 & 5 & 6 & 7 & 8 & 9 & 10 & D10-D1 \\
\hline \multicolumn{12}{|c|}{ Net Return } \\
\hline \multirow[t]{2}{*}{ Average } & 0.82 & 0.82 & 0.79 & 0.83 & 0.76 & 0.80 & 0.74 & 0.74 & 0.69 & 0.64 & $-0.17 * * *$ \\
\hline & $(2.81)$ & $(2.77)$ & $(2.72)$ & $(2.85)$ & $(2.66)$ & $(2.73)$ & $(2.54)$ & $(2.53)$ & $(2.30)$ & $(2.17)$ & $(-3.07)$ \\
\hline \multirow{2}{*}{$\mathrm{CAPM} \alpha$} & 0.05 & 0.04 & 0.02 & 0.06 & 0.00 & 0.03 & -0.03 & -0.03 & -0.09 & -0.13 & $-0.19 * * *$ \\
\hline & $(0.70)$ & $(0.65)$ & $(0.34)$ & $(0.92)$ & $(0.04)$ & $(0.49)$ & $(-0.55)$ & $(-0.59)$ & $(-1.71)$ & $(-2.39)$ & $(-3.18)$ \\
\hline \multirow{2}{*}{$\mathrm{FF} \alpha$} & -0.01 & -0.01 & -0.04 & 0.00 & -0.06 & -0.02 & -0.07 & -0.07 & -0.12 & -0.16 & $-0.15 * * *$ \\
\hline & $(-0.13)$ & $(-0.27)$ & $(-0.89)$ & $(0.03)$ & $(-1.22)$ & $(-0.46)$ & $(-1.36)$ & $(-1.53)$ & $(-2.47)$ & $(-2.93)$ & $(-2.8)$ \\
\hline \multirow{2}{*}{ Carhart $\alpha$} & -0.01 & -0.03 & -0.04 & -0.01 & -0.06 & -0.01 & -0.05 & -0.06 & -0.12 & -0.14 & $-0.14 * *$ \\
\hline & $(-0.09)$ & $(-0.46)$ & $(-0.73)$ & $(-0.12)$ & $(-1.19)$ & $(-0.26)$ & $(-1.02)$ & $(-1.27)$ & $(-2.3)$ & $(-2.42)$ & $(-2.57)$ \\
\hline \multirow[t]{2}{*}{ PS $\alpha$} & -0.03 & -0.05 & -0.05 & -0.02 & -0.07 & -0.02 & -0.07 & -0.07 & -0.13 & -0.16 & $-0.12 * *$ \\
\hline & $(-0.53)$ & $(-0.91)$ & $(-0.91)$ & $(-0.41)$ & $(-1.51)$ & $(-0.41)$ & $(-1.3)$ & $(-1.3)$ & $(-2.43)$ & $(-2.71)$ & $(-2.28)$ \\
\hline \multicolumn{12}{|c|}{ Gross Return } \\
\hline \multirow[t]{2}{*}{ Average } & 0.93 & 0.92 & 0.89 & 0.92 & 0.86 & 0.90 & 0.84 & 0.84 & 0.79 & 0.76 & $-0.17 * * *$ \\
\hline & (3.19) & (3.12) & (3.06) & (3.19) & $(3.00)$ & (3.07) & $(2.88)$ & $(2.87)$ & $(2.66)$ & $(2.55)$ & $(-3.07)$ \\
\hline \multirow[t]{2}{*}{ CAPM $\alpha$} & 0.16 & 0.15 & 0.12 & 0.16 & 0.10 & 0.13 & 0.07 & 0.07 & 0.01 & -0.02 & $-0.19 * * *$ \\
\hline & $(2.17)$ & (2.19) & (1.94) & $(2.41)$ & (1.70) & $(2.30)$ & $(1.25)$ & (1.32) & $(0.19)$ & $(-0.39)$ & $(-3.17)$ \\
\hline \multirow[t]{2}{*}{$\mathrm{FF} \alpha$} & 0.10 & 0.09 & 0.06 & 0.10 & 0.04 & 0.08 & 0.03 & 0.03 & -0.02 & -0.04 & $-0.15 * * *$ \\
\hline & (1.64) & $(1.72)$ & (1.18) & (1.98) & $(0.94)$ & (1.79) & $(0.64)$ & $(0.61)$ & $(-0.36)$ & $(-0.82)$ & $(-2.80)$ \\
\hline \multirow[t]{2}{*}{ Carhart $\alpha$} & 0.11 & 0.08 & 0.06 & 0.09 & 0.04 & 0.09 & 0.05 & 0.04 & -0.02 & -0.03 & $-0.14^{* *}$ \\
\hline & $(1.54)$ & (1.43) & (1.14) & (1.74) & $(0.82)$ & (1.93) & $(0.92)$ & $(0.77)$ & $(-0.31)$ & $(-0.53)$ & $(-2.57)$ \\
\hline \multirow[t]{2}{*}{ PS $\alpha$} & 0.08 & 0.06 & 0.05 & 0.08 & 0.02 & 0.08 & 0.03 & 0.03 & -0.03 & -0.05 & $-0.12 * *$ \\
\hline & $(1.17)$ & $(1.04)$ & $(0.95)$ & $(1.43)$ & $(0.52)$ & (1.69) & $(0.63)$ & $(0.66)$ & $(-0.48)$ & $(-0.79)$ & $(-2.28)$ \\
\hline
\end{tabular}




\section{Table XIV}

\section{Alternative Measures of Mutual Fund Performance}

This table presents coefficient estimates from predictive panel regressions testing the association between fund herding and future mutual fund performance. Performance is computed from fund stock holdings using two measures: the Daniel et al. (1997, DGTW) Characteristic Selectivity (CS) measure (columns (1) and (2)) and the Grinblatt and Titman (1993, GT) measure. The monthly GT measure is computed over quarter $t+1$ and over quarter $t+5$. The regressions control for fund size, age, expense ratio (percent), turnover, flows (percent) over the previous quarter, and alpha (percent) over the previous three years. Performance is measured in monthly percentages. The regressions include time fixed effects and the standard errors are clustered by fund. $t$-statistics are shown in parentheses. ${ }^{* *},{ }^{* *}$, and $*$ denote statistical significance at the $1 \%, 5 \%$, and $10 \%$ level, respectively.

\begin{tabular}{|c|c|c|c|c|c|c|}
\hline & \multirow{2}{*}{\multicolumn{2}{|c|}{$\frac{\text { DGTW Measure (CS) }}{t+1}$}} & \multicolumn{4}{|c|}{ Grinblatt-Titman Measure (GT) } \\
\hline & & & \multicolumn{2}{|c|}{$t+1$} & \multicolumn{2}{|c|}{$t+5$} \\
\hline & $(1)$ & $(2)$ & (3) & $(4)$ & $(5)$ & $(6)$ \\
\hline Fund Herding & $\begin{array}{c}-0.251 * * \\
(-2.39)\end{array}$ & $\begin{array}{c}-0.276 * * * \\
(-2.63)\end{array}$ & $\begin{array}{c}-0.208 * * \\
(-2.10)\end{array}$ & $\begin{array}{c}-0.244 * * \\
(-2.54)\end{array}$ & $\begin{array}{c}-0.173 * * \\
(-2.10)\end{array}$ & $\begin{array}{c}-0.197 * * \\
(-2.30)\end{array}$ \\
\hline Size & & $\begin{array}{l}-0.006^{*} \\
(-1.64)\end{array}$ & & $\begin{array}{l}-0.007 * \\
(-1.88)\end{array}$ & & $\begin{array}{l}-0.004 \\
(-1.17)\end{array}$ \\
\hline Age & & $\begin{array}{l}0.015 \\
(1.56)\end{array}$ & & $\begin{array}{l}-0.002 \\
(-0.25)\end{array}$ & & $\begin{array}{l}-0.003 \\
(-0.40)\end{array}$ \\
\hline Expense & & $\begin{array}{l}-0.018 \\
(-1.14)\end{array}$ & & $\begin{array}{l}0.011 \\
(0.82)\end{array}$ & & $\begin{array}{l}0.010 \\
(0.82)\end{array}$ \\
\hline Turnover & & $\begin{array}{l}-0.008 \\
(-0.92)\end{array}$ & & $\begin{array}{l}-0.007 \\
(-1.01)\end{array}$ & & $\begin{array}{l}0.007 \\
(0.95)\end{array}$ \\
\hline Flow & & $\begin{array}{l}0.005 \\
(0.32)\end{array}$ & & $\begin{array}{c}0.005 * * * \\
(13.12)\end{array}$ & & $\begin{array}{l}-0.023 \\
(-1.38)\end{array}$ \\
\hline Alpha & & $\begin{array}{l}0.022 \\
(0.96)\end{array}$ & & $\begin{array}{c}0.049 * * * \\
(2.63)\end{array}$ & & $\begin{array}{l}-0.013 \\
(-0.84)\end{array}$ \\
\hline Adj $R^{2}$ & 0.054 & 0.056 & 0.209 & 0.206 & 0.241 & 0.237 \\
\hline $\mathrm{N}$ & 136742 & 129596 & 155083 & 147358 & 132347 & 125104 \\
\hline
\end{tabular}




\section{Table XV \\ Fund Herding and Future Fund Flows}

This table presents coefficient estimates from predictive regressions testing the association between fund herding and future fund flows. The dependent variable is the net flow of a given fund during quarter $t+1$. Net flow is the growth rate of assets under management after adjusting for the appreciation of the fund's assets. The regressions control for fund size, age, expense ratio (percent), turnover, flows over the previous quarter, and alpha (percent) over the previous three years. All independent variables are measured at the end of quarter $t$. The regressions include fixed time effects and the standard errors are clustered by fund. $t$-statistics are shown in parentheses. $* * *$, **, and * denote statistical significance at the $1 \%, 5 \%$, and $10 \%$ level, respectively.

\begin{tabular}{lcc}
\hline \multicolumn{3}{c}{ Dependent Variable: Fund Flows } \\
\hline Fund Herding & $-0.033^{* *}$ & -0.019 \\
& $(-2.34)$ & $(-1.58)$ \\
Size & & $-0.003^{* * *}$ \\
& & $(-5.85)$ \\
Age & $-0.009 * * *$ \\
& & $(-7.58)$ \\
Expense & 0.131 \\
& & $(0.60)$ \\
Turnover & 0.002 \\
& & $(0.99)$ \\
Flow & $0.192^{* * *}$ \\
& & $(11.13)$ \\
Alpha & & $5.758^{* * *}$ \\
& & $(19.67)$ \\
Adj $\mathrm{R}^{2}$ & & \\
$\mathrm{~N}$ & 0.010 & 0.084 \\
& 55595 & 53002 \\
\hline
\end{tabular}




\title{
Internet Appendix for
}

\section{"Does Herding Behavior Reveal Skill?}

\section{An Analysis of Mutual Fund Performance"}

\author{
HAO JIANG and MICHELA VERARDO*
}

\footnotetext{
${ }^{*}$ Citation format: Jiang, Hao, and Michela Verardo, Internet Appendix for "Does Herding Behavior Reveal Skill? An Analysis of Mutual Fund Performance," Journal of Finance [DOI String]. Please note: Wiley-Blackwell is not responsible for the content or functionality of any additional information provided by the authors. Any queries (other than missing material) should be directed to the authors of the article.
} 


\section{Introduction}

In this Internet Appendix we provide supplementary material and robustness tests on the relation between herding behavior and mutual fund skill. This document is organized as follows. Section II examines the link between herding and performance using the LSV measure; the results of this analysis highlight the value of developing a dynamic measure to capture the tendency of individual funds to follow past institutional trading decisions. Section III presents results on the herding-performance relation when we use a narrower definition for the crowd that mutual funds imitate; in particular, we restrict the crowd to include: (i) only mutual funds, (ii) the subset of mutual funds with relatively high past performance, and (iii) the subset of peer mutual funds based on investment style. Section IV contains a set of robustness tests that use alternative approaches to measuring fund herding. For example, we consider: fund trades that include initiations and deletions; trades defined as changes in portfolio weights; estimating a fund's herding tendency with no controls, controlling for industry momentum, and controlling for contemporaneous institutional trades; defining herding as a fund's tendency to follow longer-horizon institutional trades. Section V presents results on buy herding and sell herding. Section VI presents a number of further tests on the robustness of the relation between fund herding and future performance.

\section{Comparison with the LSV Measure}

The popular stock-level measure of herding proposed by Lakonishok, Shleifer, and Vishny (1992, LSV) captures the tendency of investors to buy and sell the same stocks at the same time. Our measure of fund herding differs from this measure in that it captures the intertemporal correlation between a fund's trades and past aggregate institutional trades. To better understand the importance of this intertemporal focus, we follow Grinblatt, Titman, and Wermers (1995) and create a fund-level measure of herding by aggregating the stock-level LSV measure of each stock $i$ traded by each fund $j$ :

$$
F H_{j, t}^{L S V}=\sum_{i=1}^{N_{i, t}}\left[\Delta w_{i, t}^{j} \times H M_{i, t} \times I\left(p_{i, t}>\bar{p}_{i, t}\right)\right],
$$

where $w_{i, t}^{j}$ is the weight of stock $i$ in fund $j$ at the end of quarter $t ; p_{i, t}$ is the fraction of mutual funds trading stock $i$ in quarter $t$ that are buyers; $H M_{i, t}$ is the LSV herding measure for stock $i$ in quarter $t: H M_{i, t}=\left|p_{i, t}-\bar{p}_{i, t}\right|-E\left(\left|p_{i, t}-\bar{p}_{i, t}\right|\right)$; and $I\left(p_{i, t}>\bar{p}_{i, t}\right)=1$ if $p_{i, t-1}>\bar{p}_{i, t-1}, I\left(p_{i, t}>\bar{p}_{i, t}\right)=-1$ if 
$p_{i, t-1}<\bar{p}_{i, t-1}$.

We next test the ability of $F H_{j, t}^{L S V}$ to predict mutual fund performance by sorting funds into decile portfolios based on this new measure of herding and estimating their subsequent returns. The results, reported in Table IA.I, show that this measure of herding is not significantly related to future performance. This evidence suggests that our intertemporal measure of fund herding reveals a dimension of mutual fund skill that is not detectable with a traditional, more static measure of trade clustering, and this highlights the importance of focusing on the dynamic tendency of individual funds to follow past institutional trading decisions.

\section{Following a Smaller Crowd}

In our baseline analysis we measure herding as the tendency of a mutual fund to follow the trades of the institutional crowd, defined as the aggregate trades of all institutional investors. In this section we consider a number of narrower definitions for the crowd that mutual funds imitate. In particular, we restrict the crowd to include: (i) only mutual funds, (ii) the subset of mutual funds with relatively high past performance (past winners), and (iii) the subset of peer mutual funds, that is, mutual funds that follow the same investment style or have the same investment objective as the fund that we are analyzing. We estimate regressions of fund trades on the past trades of the crowd, as in our baseline analysis, to construct new measures of fund herding and assess their ability to predict performance.

Overall, our investigation of herding as imitation of a selected group of institutions suggests that the predictability of herding for mutual fund performance is clear and strong when we measure herding as imitation of the broad crowd of investors. When we use a narrower definition of the set of institutions that mutual funds might imitate, the link between herding and future performance is not as important in magnitude or statistical significance. Taken together, our results suggest that our measure of imitation, based on "following the crowd," is better able to detect skill in the cross-section of mutual funds.

\section{A. Following Mutual Funds}

We first consider a fund's tendency to follow the past trading decisions of mutual funds as a group. We replace aggregate institutional trades with aggregate mutual fund trades in our trade 
regression:

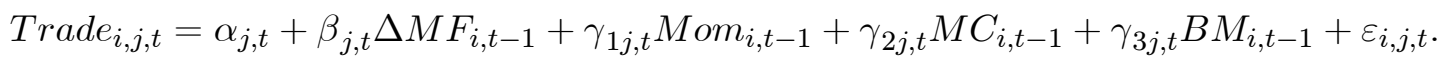

We then use these quarterly coefficients to construct a new measure of herding, as in our baseline case, and relate it to future fund performance. The results, reported in Table IA.II, indicate that the tendency to follow aggregate mutual fund trades is a useful measure to forecast future fund performance, although it is less powerful than a measure based on the tendency to follow the crowd.

\section{B. Following Successful Mutual Funds}

We next consider a fund's tendency to follow the past trading decisions of successful mutual funds only. Each quarter, we define successful mutual funds as those funds with prior-year threefactor alphas in the top $20 \%$ of the cross-fund distribution. We then estimate the trade regressions after replacing aggregate institutional trades with the trades of these successful funds and, as before, we use the estimated quarterly coefficients to construct a new measure of herding and predict fund performance.

Table IA.III shows that the performance gap between herding and antiherding funds is not significant. Compared to our baseline case scenario, these results indicate that differences in the tendency to follow past winners, which we can loosely term as copycatting star mutual funds, might not be a highly effective signal to identify skill. This result is consistent with the copycat literature, which finds little evidence that imitating successful managers can systematically lead to superior performance (Frank et al. (2004), Verbeek and Wang (2013), Phillips, Pukthuanthong, and Rau (2014)). Our findings highlight the importance of using the tendency to follow the crowd as a signal to separate skilled and unskilled mutual funds.

\section{Following Style Peers}

To measure herding on style peers, we modify the definition of crowd to include only those mutual funds that can be viewed as peers based on their investment style or investment objective. We define style peers in three ways:

i. Using the 12 styles as defined in the Equity Fund Classification Matrix of Lipper: Large-Cap Value, Large-Cap Core, Large-Cap Growth, Multi-Cap Value, Multi-Cap Core, Multi-Cap 
Growth, Mid-Cap Value, Mid-Cap Core, Mid-Cap Growth, Small-Cap Value, Small-Cap Core, and Small-Cap Growth;

ii. Focusing on the four non-overlapping extreme styles: Large-Cap Value, Large-Cap Growth, Small-Cap Value, and Small-Cap Growth;

iii. Using the Thomson-Reuters mutual fund investment objective code to group funds into three styles: Aggressive Growth, Growth, and Growth and Income.

We reestimate fund herding based on these new proxies for the trades of the crowd, and measure subsequent fund performance. We present the results in Table IA.IV (Panels A, B, and C). The average spread in returns (gross and net) between herding and antiherding funds is negative, ranging from $-10 \mathrm{bps}$ to $-13 \mathrm{bps}$, and is significant at the $10 \%$ level. However, the spread in Carhart alphas, although similar in magnitude, is not statistically significant. The results from these tests suggest that the tendency of mutual funds to imitate their style peers does not reliably capture the heterogeneity in skill across mutual funds.

\section{Robustness of the Fund Herding Measure}

In this section we check the robustness of our fund herding measure with a number of different empirical tests. First, we consider different approaches to measuring mutual fund trades. Second, we consider different control variables in the baseline regressions of fund trades on past aggregate institutional trades. Third, we estimate mutual fund herding with respect to past long-horizon institutional trades. Finally, we examine different ways of averaging the quarterly coefficients used to construct a fund's average tendency to herd.

\section{A. Trades with Initiations and Deletions}

Our baseline measure of trade is the percentage change in holdings of stock $i$ in the portfolio of mutual fund $j$ during quarter $t$, where holdings are measured as the number of split-adjusted shares. This measure of trade captures all purchases and sales by a mutual fund, excluding initiations and deletions of positions in a given stock. In this subsection we test the link between fund herding and performance when herding is computed from trades that also include initiations and deletions. Table IA.V shows that the performance of funds sorted on fund herding is very similar to our 
baseline results. For example, the Carhart alpha differential between herding and antiherding funds is $-14 \mathrm{bps}$, similar to the baseline case of $-16 \mathrm{bps}$. We conclude that initiations and deletions do not affect our results significantly.

\section{B. Trades as Changes in Portfolio Weights}

We next recompute fund herding after measuring a fund's trades as the change in portfolio weight in a given stock in a given quarter. Table IA.VI reports the performance of portfolios of funds that are sorted by this measure of fund herding. The results are very similar, and if anything slightly stronger, than our baseline results. For example, the difference in raw returns between herding and antiherding funds is -20bps (compared to -19bps in our baseline case), and the difference in Carhart alphas is now -21 bps (compared to $-16 \mathrm{bps}$ in our baseline case). We conclude that our results are robust to the method of fund trade measurement.

\section{Controlling for Industry Momentum}

Prior work presents evidence of gradual diffusion of industry-level information into stock prices, which could have implications for the tendency of mutual funds to herd (Hou (2007)). To assess the importance of industry momentum in prices, we reestimate fund herding using a trade regression that includes $\mathrm{Mom}_{\operatorname{Ind}_{i}, t-1}$, the industry-level return measured in the previous quarter. We use the Fama and French (1997) 10-industry classification. The trade regressions are modified as follows:

$\operatorname{Trade}_{i, j, t}=\alpha_{j, t}+\beta_{j, t} \Delta I O_{i, t-1}+\gamma_{1 j, t} \operatorname{Mom}_{i, t-1}+\gamma_{2 j, t} M C_{i, t-1}+\gamma_{3 j, t} B M_{i, t-1}+\gamma_{4 j, t} M_{o m} \operatorname{Ind}_{i, t-1}+\varepsilon_{i, j, t}$.

As with our baseline analysis, we average the quarterly coefficients on $\Delta I O$ to construct a new measure of fund herding. We then assess its ability to predict performance for the crosssection of mutual funds. The results, reported in Table IA.VII, confirm that the return spread between herding and antiherding funds remains large and statistically significant after controlling for industry momentum.

\section{Controlling for Contemporaneous Institutional Trades}

If aggregate institutional trades are persistent over time, they might play a role in driving the correlation between the current trades of a mutual fund and past institutional trades. To control 
for this possibility, we reconstruct our measure of herding from a trade regression that includes the current change in institutional ownership for stock $i, \Delta I O_{i, t}$ :

$\operatorname{Trade}_{i, j, t}=\alpha_{j, t}+\beta_{j, t} \Delta I O_{i, t-1}+\gamma_{1 j, t} M_{o m} m_{i, t-1}+\gamma_{2 j, t} M C_{i, t-1}+\gamma_{3 j, t} B M_{i, t-1}+\gamma_{4 j, t} \Delta I O_{i, t}+\varepsilon_{i, j, t}$.

The results are reported in Table IA.VIII. We find that even after controlling for the influence of contemporaneous institutional trades, fund herding is negatively and significantly associated with future performance.

\section{E. No Controls}

We next investigate the link between fund herding and future fund performance when herding is estimated without controlling for investment styles (size, value, momentum). The main rationale for our style controls is to capture a fund's tendency to imitate the crowd for reasons other than following the same investment style as the crowd. For example, if we didn't control for value, we might attribute herding behavior to a manager who appears to follow the crowd but is really implementing value strategies, possibly together with a fraction of institutional investors. With the controls we hope to separate deliberate imitating behavior from apparent imitation that might be due to commonalities in investing styles.

In this subsection we rerun our portfolio analysis by sorting funds on a measure of herding that is obtained from our baseline regression of fund trades on $\Delta I O$ without including any controls. The results are presented in Table IA.IX. They are similar to our baseline results, albeit less strong. For example, the difference in Carhart alphas between herding and antiherding funds is now $-12 \mathrm{bps}$ for net returns and $-13 \mathrm{bps}$ for gross returns, significant at the $10 \%$ level (compared to $-16 \mathrm{bps}$ in the baseline case). These results suggest that the measure of herding obtained without style controls is a less clean measure of imitation; as with measures previously used in the literature (e.g., Grinblatt, Titman, and Wermers (1995)), this measure may not capture pure imitating behavior, since the estimated correlation between fund trades and institutional trades is potentially confounded by trading decisions that are based on common preferences for investing styles and feedback trading. This evidence emphasizes the importance of filtering out information on stock characteristics to obtain a cleaner estimate of herding behavior, which can reveal cross-sectional differences in mutual fund skill. 


\section{F. Following Longer-Horizon Institutional Trades}

In our baseline analysis we define fund herding as the average correlation between a fund's trades and past aggregate institutional trades, measured over two adjacent quarters. We now modify our measure of fund herding to capture the behavior of mutual funds following institutional herds that have developed over longer periods of time. Specifically, for any given stock, we construct three measures of long-horizon institutional trades: aggregate institutional trades over the past two quarters, $\Delta I O_{i, t-2: t-1}$; aggregate institutional trades over the past four quarters, $\Delta I O_{i, t-4: t-1}$; and a measure of persistence in past institutional trades, which counts the number of consecutive quarters in which the stock is bought or sold by institutional investors and attributes positive values to buy decisions and negative values to sell decisions, $\operatorname{Per} s_{i, t-1} \cdot{ }^{1}$

At the end of each quarter $t$, we reestimate our basic trade regression using each of the longerhorizon measures of past institutional trades measured up to the end of quarter $t-1$, with the usual stock characteristics to control for style. For example, with Pers $s_{i, t-1}$ we estimate the following regression:

$$
\operatorname{Trade}_{i, j, t}=\alpha_{j, t}+\beta_{j, t} \operatorname{Pers}_{i, t-1}+\gamma_{1 j, t} \operatorname{Mom}_{i, t-1}+\gamma_{2 j, t} M C_{i, t-1}+\gamma_{3 j, t} B M_{i, t-1}+\varepsilon_{i, j, t} .
$$

The coefficient $\beta_{j, t}$ now represents the responsiveness of the trades of mutual fund $j$ to different degrees of persistence in buying or selling by institutional investors, measured over horizons of several quarters in the past. We then use these quarterly coefficients to construct a new measure of herding, as in our baseline case.

Table IA.X (Panels A, B, and C) presents results from panel regressions of fund performance on these new measures of herding. The findings indicate that the tendency of mutual funds to follow past institutional trades negatively predicts their future performance, especially when past aggregate trades are persistent or are measured in the more recent past.

\footnotetext{
${ }^{1} \mathrm{~A}$ stock is bought (sold) if the change in institutional ownership in a given quarter is above (below) the crosssectional median. For example, for a stock bought in quarter $t$ and sold in quarter $t-1$ trade persistence equals +1 , while for a stock bought in quarters $t$ and $t-1$ and sold in $t-2$, trade persistence equals +2 . Stocks that are bought or sold for at least four consecutive quarters have a trade persistence value of +4 and -4 , respectively. Dasgupta, Prat, and Verardo (2011) document empirically that stocks persistently bought or sold by institutional investors experience return reversals in the long run.
} 


\section{G. Alternative Approaches to Constructing Fund Herding}

In this subsection we further consider alternative approaches to constructing our measure of fund herding. First, we compute a fund's average tendency to herd using the equally weighted time-series average of the quarterly herding coefficients from the trade regressions (Table IA.XI). Second, we simply use the quarterly coefficients from the trade regressions as proxies for mutual fund herding (Table IA.XII). Third, we estimate the fund trade regressions without standardizing the dependent and independent variables (Table IA.XIII). The results indicate that the relation between fund herding and future performance is robust to these alternative estimates of fund herding. In particular, this investigation highlights the importance of measuring fund herding using all information available on a fund's trading behavior up to quarter $t$, rather than truncating the information set to the most recent past. At the same time, our findings emphasize the importance of allowing for time-varying changes in funds' trading behavior, rather than attributing the same weight to both recent and past actions.

\section{Buy Herding and Sell Herding}

In our baseline analysis, we construct fund herding using all available information on funds' behavior with respect to the past decisions of the institutional crowd. In this section, we separate out buys and sells to check for asymmetries in the strength of the performance signal coming from imitating aggregate buys and aggregate sells. Specifically, we sort past aggregate trades $(\Delta I O)$ into buys and sells based on their sign and estimate regressions of funds' trades on these measures. Using the beta coefficients from these regressions, we construct each fund's average tendency to follow past buys (FH/buys) and past sells (FH/sells). We then form decile portfolios of funds based on buy herding and sell herding and estimate their future performance. The results from these univariate sorts are reported in Table IA.XIV (Panels A and B). The evidence indicates that there is no clear difference in the ability of fund herding and sell herding to predict mutual fund performance. The difference in raw returns between herding and antiherding funds (deciles 10 and 1) is slightly larger for buy herding (17bps versus 13bps), but the difference in Carhart alphas varies between $9 \mathrm{bps}$ and 10bps. Overall, these return differentials are somewhat weaker than those

reported for our pooled sample of trades. However, this test does not account for the degree to which any given fund might engage in both buy herding behavior and sell herding behavior. 
For a more powerful test of potential asymmetries between buy herding and sell herding, we consider funds that are double-sorted based on their propensity to imitate past aggregate buys or sells. This test allows us to analyze the incremental value of buy herding and sell herding for predicting fund performance. We sort all funds independently into quartiles based on $\mathrm{FH} / \mathrm{buys}$ and $\mathrm{FH} /$ sells, and we estimate their future performance. Table IA.XV reports the raw returns and the four-factor alphas of the portfolios. The table shows that, conditional on sell herding, the difference in future performance between funds that herd and funds that antiherd on past buys (High-Low/buys) is both large and significant for low and medium sell herding. In particular, the performance differentials are $-13 \mathrm{bps}$ and $-12 \mathrm{bps}$ when measured in raw returns (significant at the $5 \%$ level), and -10bps when measured using the four-factor alphas (with $t$-statistics around 1.80). This evidence suggests that, controlling for a fund's tendency to imitate past institutional selling activity, the tendency to follow aggregate buys contains incremental information for a fund's future performance. In contrast, we do not observe significant return differentials between herding and antiherding funds following aggregate sells. These results are consistent with the intuition that herding behavior can reveal differences in skill more clearly when considering buy herding than when considering sell herding.

\section{Other Robustness Tests}

\section{A. Price Pressure from Institutional Trades}

One possible driver of the link between herding and future performance might be the price impact of aggregate institutional trades. If institutional trades exert destabilizing pressure on prices, then fund managers who follow these trades may "buy high and sell low," thus achieving on average inferior performance. This hypothesis relies crucially on the premise that aggregate institutional trades predict reversals in stock returns, and that such return reversals occur in the period in which we evaluate mutual fund performance.

To examine this conjecture, we investigate the relation between aggregate institutional trades and future stock returns. In particular, for each month from January 1990 to December 2009, we estimate the ability of changes in aggregate institutional ownership to predict monthly stock returns measured in the subsequent four quarters, after controlling for a variety of stock characteristics. Table IA.XVI presents the results. In the first specification we include firm size, book-to-market, 
stock returns in the previous quarter, and stock returns in the previous year. In the second specification we add stock turnover, idiosyncratic volatility, share issuance, and analyst earnings forecast revisions. We use the Fama and MacBeth (1973) procedure to conduct statistical inference.

Aggregate institutional trades are measured in quarter $t$. The results from the predictive regressions show that the slope coefficients on institutional trades are statistically indistinguishable from zero for all forecasting horizons $t+1$ to $t+4$ and for both regression specifications. To map the forecasting horizon of this regression to our investigation of mutual fund herding and performance, we note that if quarter $t$ is the period in which we measure aggregate institutional trades, then individual mutual fund trades are measured in quarter $t+1$ and mutual fund performance is measured over quarter $t+2$. The results suggest that, at least for the sample period we consider, aggregate institutional trades have no predictive power for the cross-section of stock returns. Based on this evidence, we can rule out the possibility that the underperformance of herding funds arises mainly from price pressure caused by aggregate institutional trades.

\section{B. Excluding Funds with Highest and Lowest Fund Herding}

We examine the robustness of the predictive power of herding for mutual fund performance by estimating multivariate regressions that exclude funds in the top and bottom deciles of fund herding. Our measure of performance is the monthly four-factor alpha of Carhart (1997), estimated in the months of quarter $t+1$ as the difference between the realized fund return in excess of the risk-free rate and the expected excess fund return from a four-factor model that includes the market, size, value, and momentum factors. The factor loadings are estimated from rolling-window time-series regressions of fund returns over the previous three years. Herding and fund characteristics are measured using information available at the end of quarter $t$.

Table IA.XVII presents the results from the predictive panel regressions. The results provide further evidence of a significant link between fund herding and future performance, even after we remove the funds in the extreme deciles of fund herding.

\section{Value-Weighted Fund Portfolios}

We next reestimate the herding-performance relation using value-weighted deciles of funds rather than equally weighted portfolios. The weights for individual funds are based on the funds' 
total net assets. We measure the future returns of these portfolios and estimate their risk-adjusted returns from time-series regressions using the capital asset pricing model (CAPM), the three-factor model of Fama and French (1993), the four-factor model of Carhart (1997), and the five-factor model of Pástor and Stambaugh (2003). Table IA.XVIII presents the results. Herding funds in decile 10 strongly underperform their antiherding peers in decile 1 . The magnitude of the return differentials is larger than that based on equally weighted fund portfolio returns, suggesting that the performance implications of mutual fund herding are not confined to small funds.

\section{Fund Herding and Stock Characteristics}

In our main analysis, as a robustness check, we estimate fund herding from trade regressions that control for a large number of stock characteristics: size, book-to-market, momentum, stock turnover, idiosyncratic volatility, revisions in analyst earnings forecasts, past share issuance, bid-ask spread, Amihud illiquidity, and 10 industry dummies. When we estimate the future performance of mutual funds sorted on this new measure of herding, we find that the performance differential between herding and antiherding funds is remarkably similar to our baseline case (Carhart alphas are -15 bps per month when using all controls, indistinguishable from the benchmark value of $-16 \mathrm{bps})$.

In this subsection, we perform another test to investigate whether funds with different propensity to herd might hold stocks with different characteristics, thus driving the return differential across funds. In particular, we compute the average decile rank of the distribution of a given stock characteristic for each decile of fund herding. We consider stock size, book-to-market, momentum, and institutional ownership. Table IA.XIX reports the results. There is clearly no discernible variation in stock characteristics across fund herding deciles, which confirms that stock characteristics are not important drivers of the herding-performance relation that we uncover in our study.

\section{E. Reliance on Information from Past Institutional Trades}

In this subsection we estimate the herding-performance relation while controlling for the degree to which mutual fund managers rely on information contained in past institutional trades. We use

the $R^{2}$ from the regressions of individual funds' trades on past changes in institutional ownership $(\Delta I O)$ as a proxy for funds' reliance on past institutional trades. If skilled funds disregard the 
information contained in $\Delta I O$ and unskilled funds heavily rely on this information, we would expect this proxy to have a negative and significant impact on future performance; at the same time, our fund herding measure would become redundant in the performance regressions. Table IA.XX presents the results. The estimates show that $R^{2}$ does not have significant power to predict mutual fund performance, whereas fund herding retains its economic and statistical significance. These results confirm that the tendency of a fund to imitate or anti-imitate past aggregate trading decisions contains information that is useful to detect skill. 


\section{REFERENCES}

Carhart, Mark M., 1997, On Persistence in Mutual Fund Performance, Journal of Finance 52, $57-82$.

Dasgupta, Amil, Andrea Prat, and Michela Verardo, 2011, Institutional Trade Persistence and Long-Term Equity Returns, Journal of Finance 66, 635-653.

Fama, Eugene, and Kenneth R. French, 1993, Common Risk Factors in the Returns on Stocks and Bonds, Journal of Financial Economics 33, 3-56.

Fama, Eugene F., and Kenneth R. French, 1997, Industry Costs of Equity, Journal of Financial Economics 43, 153-193.

Fama, Eugene, and James MacBeth, 1973, Risk, Return, and Equilibrium: Empirical Tests, Journal of Political Economy 81, 607-636.

Frank, Mary Margaret, James M. Poterba, Douglas A. Shackelford, and John B. Shoven, 2004, Copycat Funds: Information Disclosure Regulations and the Returns to Active Management in the Mutual Fund Industry, Journal of Law and Economics 47, 515-41.

Grinblatt, Mark, Sheridan Titman, and Russ Wermers, 1995, Momentum Investment Strategies, Portfolio Performance, and Herding: a Study of Mutual Fund Behavior, American Economic Review $85,1088-1105$.

Hou, Kewei, 2007, Industry Information Diffusion and the Lead-lag Effect in Stock Returns, Review of Financial Studies 20, 1113-1138.

Lakonishok, Josef, Andrei Shleifer, and Robert W. Vishny, 1992, The Impact of Institutional Trading on Stock Prices, Journal of Financial Economics 32, 23-43.

Newey, Whitney K., and Kenneth D. West, 1987, A simple, positive semi-definite, heteroskedasticity and autocorrelation consistent covariance matrix, Econometrica 55, 703-708.

Pástor, Lubos, and Robert F. Stambaugh, 2003, Liquidity Risk and Expected Stock Returns, Journal of Political Economy 111, 642-685.

Phillips, Blake, Kuntara Pukthuanthong, and P. Raghavendra Rau, 2014, Detecting Superior Mutual Fund Managers: Evidence from Copycats, Review of Asset Pricing Studies 4, 286-321.

Verbeek, Marno, and Yu Wang, 2013, Better than the Original? The Relative Success of Copycat Funds, Journal of Banking and Finance 37, 3454-71. 
Table IA.I

Fund Herding Measured from LSV Stock Herding

This table presents the performance of decile portfolios of funds formed on the basis of their herding measure. A fund's herding measure is computed by aggregating the stock-level LSV herding measure of its holdings using its portfolio weights. The decile portfolios are formed at the end of each quarter from 1989Q4 to 2009Q3 and held for one quarter. The return series span January 1990 to December 2009. Decile 10 is the portfolio of funds with the highest fund herding measure. We compute monthly equally weighted net and gross (net plus expense ratio) returns on the portfolios, as well as risk-adjusted returns based on the CAPM, the Fama and French (1993, FF) three-factor model, the Carhart (1997) four-factor model, and the Pastor and Stambaugh (2003, PS) five-factor model. Average returns and alphas are in monthly percentages. Newey-West (1987) $t$-statistics are shown in parentheses. ${ }^{* * *},{ }^{* *}$, and $*$ denote statistical significance at the $1 \%$, $5 \%$, and $10 \%$ level, respectively, for the return differentials between deciles 10 and 1 .

\begin{tabular}{|c|c|c|c|c|c|c|c|c|c|c|c|}
\hline FH rank & 1 & 2 & 3 & 4 & 5 & 6 & 7 & 8 & 9 & 10 & D10-D1 \\
\hline \multicolumn{12}{|c|}{ Net Return } \\
\hline \multirow[t]{2}{*}{ Average } & 0.75 & 0.73 & 0.75 & 0.71 & 0.71 & 0.73 & 0.74 & 0.76 & 0.83 & 0.87 & 0.12 \\
\hline & $(2.73)$ & $(2.74)$ & $(2.82)$ & $(2.60)$ & $(2.54)$ & $(2.59)$ & $(2.54)$ & $(2.42)$ & $(2.41)$ & $(2.17)$ & $(0.52)$ \\
\hline \multirow[t]{2}{*}{$\mathrm{CAPM} \alpha$} & 0.01 & 0.00 & 0.02 & -0.03 & -0.05 & -0.03 & -0.03 & -0.04 & 0.00 & -0.01 & -0.02 \\
\hline & $(0.15)$ & $(0.05)$ & $(0.38)$ & $(-0.54)$ & $(-0.9)$ & $(-0.47)$ & $(-0.52)$ & $(-0.49)$ & $(0.02)$ & $(-0.03)$ & $(-0.08)$ \\
\hline \multirow[t]{2}{*}{ FF $\alpha$} & -0.07 & -0.08 & -0.06 & -0.10 & -0.11 & -0.08 & -0.07 & -0.06 & 0.00 & 0.02 & 0.10 \\
\hline & $(-1.21)$ & $(-1.57)$ & $(-1.08)$ & $(-1.99)$ & $(-2.53)$ & $(-1.64)$ & $(-1.53)$ & $(-1.08)$ & $(0.05)$ & $(0.25)$ & $(0.89)$ \\
\hline \multirow[t]{2}{*}{ Carhart $\alpha$} & -0.04 & -0.04 & -0.01 & -0.07 & -0.09 & -0.07 & -0.07 & -0.09 & -0.06 & -0.09 & -0.05 \\
\hline & $(-0.63)$ & $(-0.68)$ & $(-0.13)$ & $(-1.32)$ & $(-1.96)$ & $(-1.35)$ & $(-1.45)$ & $(-1.55)$ & $(-0.91)$ & $(-0.95)$ & $(-0.47)$ \\
\hline \multirow[t]{2}{*}{$\operatorname{PS} \alpha$} & -0.06 & -0.06 & -0.03 & -0.10 & -0.10 & -0.09 & -0.08 & -0.10 & -0.05 & -0.08 & -0.02 \\
\hline & $(-1)$ & $(-1.06)$ & $(-0.53)$ & $(-1.92)$ & $(-2.36)$ & $(-1.77)$ & $(-1.77)$ & $(-1.78)$ & $(-0.81)$ & $(-0.87)$ & $(-0.17)$ \\
\hline \multicolumn{12}{|c|}{ Gross Return } \\
\hline \multirow[t]{2}{*}{ Average } & 0.87 & 0.83 & 0.85 & 0.81 & 0.81 & 0.83 & 0.85 & 0.86 & 0.94 & 1.00 & 0.13 \\
\hline & $(3.16)$ & $(3.14)$ & $(3.20)$ & $(2.97)$ & $(2.90)$ & (2.94) & (2.89) & $(2.76)$ & $(2.75)$ & $(2.51)$ & $(0.58)$ \\
\hline $\mathrm{CAPM} \alpha$ & $(1.81)$ & $(1.60)$ & (1.88) & (1.19) & (1.07) & (1.36) & $(1.25)$ & $(0.83)$ & $(0.97)$ & $(0.68)$ & $(-0.02)$ \\
\hline \multirow[t]{2}{*}{$\mathrm{FF} \alpha$} & 0.08 & 0.07 & 0.09 & 0.03 & 0.01 & 0.03 & 0.04 & 0.02 & 0.05 & 0.05 & -0.03 \\
\hline & $(1.27)$ & $(1.27)$ & $(1.71)$ & $(0.65)$ & $(0.25)$ & $(0.63)$ & $(0.75)$ & $(0.29)$ & $(0.82)$ & $(0.52)$ & $(-0.34)$ \\
\hline \multirow[t]{2}{*}{ Carhart $\alpha$} & 0.05 & 0.02 & 0.04 & 0.00 & -0.01 & 0.02 & 0.03 & 0.05 & 0.12 & 0.16 & 0.11 \\
\hline & $(0.73)$ & $(0.38)$ & $(0.75)$ & 0.00 & $(-0.22)$ & $(0.48)$ & $(0.76)$ & $(0.85)$ & (1.78) & $(1.65)$ & $(1.01)$ \\
\hline \multirow[t]{2}{*}{ PS $\alpha$} & 0.06 & 0.05 & 0.07 & 0.01 & 0.00 & 0.01 & 0.02 & 0.00 & 0.06 & 0.05 & 0.00 \\
\hline & $(0.90)$ & $(0.91)$ & $(1.32)$ & $(0.12)$ & $(-0.1)$ & $(0.21)$ & $(0.42)$ & $(0.05)$ & $(0.89)$ & $(0.58)$ & $(-0.04)$ \\
\hline
\end{tabular}




\section{Table IA.II}

\section{Fund Herding Following a Smaller Crowd: Mutual Funds}

This table presents the performance of decile portfolios formed on the basis of $F H$, the average tendency of mutual funds to follow past mutual fund trades. FH is constructed from the slope coefficient of cross-sectional regressions of mutual fund trades on aggregate mutual fund trades measured in the previous quarter, controlling for past stock returns, firm size, and the book-to-market ratio. The return series span January 1990 to December 2009 . Decile 10 is the portfolio of funds with the highest fund herding measure. We compute monthly equally weighted net and gross (net plus expense ratio) returns on the portfolios, as well as risk-adjusted returns based on the CAPM, the Fama and French (1993, FF) three-factor model, the Carhart (1997) four-factor model, and the Pastor and Stambaugh (2003, PS) five-factor model. Average returns and alphas are in monthly percentages. Newey-West (1987) $t$-statistics are shown in parentheses. ***,**, and * denote statistical significance at the $1 \%, 5 \%$, and $10 \%$ level, respectively, for the return differentials between deciles 10 and 1 .

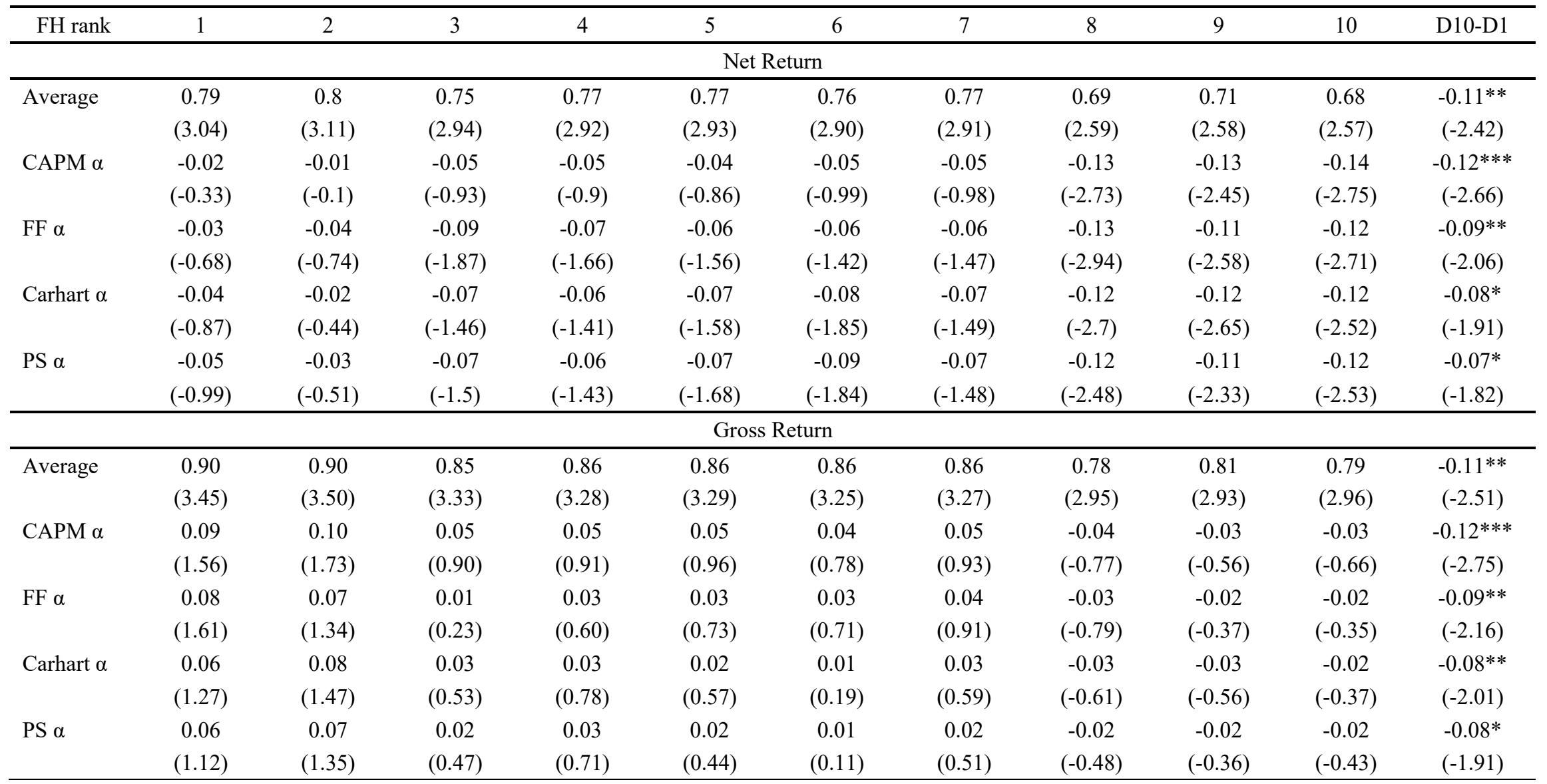


Table IA.III

Fund Herding Following a Smaller Crowd: Successful Mutual Funds

This table presents the performance of decile portfolios formed on the basis of $F H$, the average tendency of mutual funds to follow successful mutual fund trades. FH is constructed from the slope coefficient of cross-sectional regressions of mutual fund trades on past trades by successful mutual funds (funds with prior-year alpha in the top $20 \%$ of all active funds) measured in the previous quarter, controlling for past stock returns, firm size, and the book-to-market ratio. The return series span January 1990 to December 2009. Decile 10 is the portfolio of funds with the highest fund herding measure. We compute monthly equally weighted net and gross (net plus expense ratio) returns on the portfolios, as well as risk-adjusted returns based on the CAPM, the Fama and French (1993, FF) three-factor model, the Carhart (1997) four-factor model, and the Pastor and Stambaugh (2003, PS) five-factor model. Average returns and alphas are in monthly percentages. Newey-West (1987) $t$-statistics are shown in parentheses. $* * *, * *$, and $*$ denote statistical significance at the $1 \%, 5 \%$, and $10 \%$ level, respectively, for the return differentials between deciles 10 and 1 .

\begin{tabular}{|c|c|c|c|c|c|c|c|c|c|c|c|}
\hline FH rank & 1 & 2 & 3 & 4 & 5 & 6 & 7 & 8 & 9 & 10 & D10-D1 \\
\hline \multicolumn{12}{|c|}{ Net Return } \\
\hline Average & $\begin{array}{c}0.80 \\
(2.79)\end{array}$ & $\begin{array}{c}0.77 \\
(2.68)\end{array}$ & $\begin{array}{c}0.77 \\
(2.68)\end{array}$ & $\begin{array}{c}0.76 \\
(2.60)\end{array}$ & $\begin{array}{c}0.78 \\
(2.69)\end{array}$ & $\begin{array}{c}0.76 \\
(2.61)\end{array}$ & $\begin{array}{c}0.75 \\
(2.53)\end{array}$ & $\begin{array}{c}0.75 \\
(2.52)\end{array}$ & $\begin{array}{c}0.73 \\
(2.43)\end{array}$ & $\begin{array}{c}0.77 \\
(2.53)\end{array}$ & $\begin{array}{c}-0.03 \\
(-0.54)\end{array}$ \\
\hline CAPM $\alpha$ & $\begin{array}{c}0.04 \\
(0.56)\end{array}$ & $\begin{array}{c}0.01 \\
(0.10)\end{array}$ & $\begin{array}{c}0.01 \\
(0.10)\end{array}$ & $\begin{array}{c}-0.01 \\
(-0.17)\end{array}$ & $\begin{array}{c}0.01 \\
(0.24)\end{array}$ & $\begin{array}{c}-0.01 \\
(-0.21)\end{array}$ & $\begin{array}{c}-0.03 \\
(-0.41)\end{array}$ & $\begin{array}{c}-0.03 \\
(-0.57)\end{array}$ & $\begin{array}{c}-0.06 \\
(-0.98)\end{array}$ & $\begin{array}{c}-0.02 \\
(-0.37)\end{array}$ & $\begin{array}{c}-0.06 \\
(-1.08)\end{array}$ \\
\hline $\mathrm{FF} \alpha$ & $\begin{array}{c}-0.03 \\
(-0.48)\end{array}$ & $\begin{array}{c}-0.05 \\
(-0.94)\end{array}$ & $\begin{array}{c}-0.06 \\
(-1.17)\end{array}$ & $\begin{array}{l}-0.07 \\
(-1.4)\end{array}$ & $\begin{array}{c}-0.05 \\
(-0.97)\end{array}$ & $\begin{array}{c}-0.06 \\
(-1.19)\end{array}$ & $\begin{array}{c}-0.07 \\
(-1.35)\end{array}$ & $\begin{array}{l}-0.06 \\
(-1.4)\end{array}$ & $\begin{array}{c}-0.08 \\
(-1.68)\end{array}$ & $\begin{array}{c}-0.03 \\
(-0.64)\end{array}$ & $\begin{array}{c}0.00 \\
(-0.07)\end{array}$ \\
\hline Carhart $\alpha$ & $\begin{array}{c}-0.02 \\
(-0.33)\end{array}$ & $\begin{array}{c}-0.03 \\
(-0.58)\end{array}$ & $\begin{array}{c}-0.05 \\
(-0.95)\end{array}$ & $\begin{array}{c}-0.05 \\
(-1.02)\end{array}$ & $\begin{array}{c}-0.05 \\
(-0.85)\end{array}$ & $\begin{array}{c}-0.05 \\
(-0.95)\end{array}$ & $\begin{array}{c}-0.08 \\
(-1.48)\end{array}$ & $\begin{array}{c}-0.07 \\
(-1.46)\end{array}$ & $\begin{array}{c}-0.08 \\
(-1.64)\end{array}$ & $\begin{array}{c}-0.05 \\
(-0.99)\end{array}$ & $\begin{array}{c}-0.03 \\
(-0.65)\end{array}$ \\
\hline PS $\alpha$ & $\begin{array}{c}-0.03 \\
(-0.57) \\
\end{array}$ & $\begin{array}{c}-0.05 \\
(-0.88) \\
\end{array}$ & $\begin{array}{c}-0.07 \\
(-1.37) \\
\end{array}$ & $\begin{array}{c}-0.07 \\
(-1.22) \\
\end{array}$ & $\begin{array}{c}-0.07 \\
(-1.21) \\
\end{array}$ & $\begin{array}{c}-0.07 \\
(-1.28) \\
\end{array}$ & $\begin{array}{c}-0.09 \\
(-1.68) \\
\end{array}$ & $\begin{array}{c}-0.08 \\
(-1.74) \\
\end{array}$ & $\begin{array}{r}-0.09 \\
(-1.71) \\
\end{array}$ & $\begin{array}{c}-0.05 \\
(-1.00) \\
\end{array}$ & $\begin{array}{c}-0.02 \\
(-0.37) \\
\end{array}$ \\
\hline \multicolumn{12}{|c|}{ Gross Return } \\
\hline Average & $\begin{array}{c}0.91 \\
(3.16)\end{array}$ & $\begin{array}{c}0.87 \\
(3.04)\end{array}$ & $\begin{array}{c}0.87 \\
(3.02)\end{array}$ & $\begin{array}{c}0.86 \\
(2.94)\end{array}$ & $\begin{array}{c}0.88 \\
(3.03)\end{array}$ & $\begin{array}{c}0.85 \\
(2.95)\end{array}$ & $\begin{array}{c}0.85 \\
(2.87)\end{array}$ & $\begin{array}{c}0.85 \\
(2.86)\end{array}$ & $\begin{array}{c}0.83 \\
(2.77)\end{array}$ & $\begin{array}{c}0.88 \\
(2.89)\end{array}$ & $\begin{array}{c}-0.03 \\
(-0.54)\end{array}$ \\
\hline FF $\alpha$ & $\begin{array}{c}0.08 \\
(1.37)\end{array}$ & $\begin{array}{c}0.05 \\
(0.93)\end{array}$ & $\begin{array}{c}0.04 \\
(0.79)\end{array}$ & $\begin{array}{c}0.03 \\
(0.55)\end{array}$ & $\begin{array}{c}0.05 \\
(0.98)\end{array}$ & $\begin{array}{c}0.04 \\
(0.77)\end{array}$ & $\begin{array}{c}0.03 \\
(0.67)\end{array}$ & $\begin{array}{c}0.04 \\
(0.80)\end{array}$ & $\begin{array}{c}0.03 \\
(0.55)\end{array}$ & $\begin{array}{c}0.08 \\
(1.57)\end{array}$ & $\begin{array}{c}0.00 \\
(-0.06)\end{array}$ \\
\hline Carhart $\alpha$ & $\begin{array}{c}0.09 \\
(1.43)\end{array}$ & $\begin{array}{c}0.07 \\
(1.22)\end{array}$ & $\begin{array}{c}0.05 \\
(0.88)\end{array}$ & $\begin{array}{c}0.04 \\
(0.84)\end{array}$ & $\begin{array}{c}0.05 \\
(0.91)\end{array}$ & $\begin{array}{c}0.05 \\
(0.91)\end{array}$ & $\begin{array}{c}0.02 \\
(0.40)\end{array}$ & $\begin{array}{c}0.03 \\
(0.63)\end{array}$ & $\begin{array}{c}0.02 \\
(0.42)\end{array}$ & $\begin{array}{c}0.06 \\
(1.10)\end{array}$ & $\begin{array}{c}-0.03 \\
(-0.65)\end{array}$ \\
\hline PS $\alpha$ & $\begin{array}{c}0.07 \\
(1.23)\end{array}$ & $\begin{array}{c}0.05 \\
(0.91)\end{array}$ & $\begin{array}{c}0.03 \\
(0.50)\end{array}$ & $\begin{array}{c}0.03 \\
(0.59)\end{array}$ & $\begin{array}{c}0.03 \\
(0.56)\end{array}$ & $\begin{array}{c}0.03 \\
(0.51)\end{array}$ & $\begin{array}{c}0.01 \\
(0.19)\end{array}$ & $\begin{array}{c}0.02 \\
(0.34)\end{array}$ & $\begin{array}{c}0.02 \\
(0.33)\end{array}$ & $\begin{array}{c}0.06 \\
(1.07)\end{array}$ & $\begin{array}{c}-0.02 \\
(-0.37)\end{array}$ \\
\hline
\end{tabular}


Table IA.IV (A)

Fund Herding Following a Smaller Crowd: Style Peers (I)

This table presents the performance of decile portfolios formed on the basis of $F H$, the average tendency of mutual funds to follow past institutional trades. FH is constructed from the slope coefficient of cross-sectional regressions of mutual fund trades on past aggregate trades by their peer funds measured in the previous quarter, controlling for past stock returns, firm size, and the book-to-market ratio. Peer funds are defined following the 12-style Lipper mutual fund classification. The return series span January 1990 to December 2009. Decile 10 is the portfolio of funds with the highest average herding measure. We compute monthly equally weighted net and gross (net plus expense ratio) returns on the portfolios, as well as risk-adjusted returns based on the CAPM, the Fama and French (1993, FF) three-factor model, the Carhart (1997) four-factor model, and the Pastor and Stambaugh (2003, PS) five-factor model. Average returns and alphas are in monthly percentages. Newey-West (1987) $t$-statistics are shown in parentheses. $* * *, * *$, and $*$ denote statistical significance at the $1 \%, 5 \%$, and $10 \%$ level, respectively, for the return differentials between deciles 10 and 1 .

\begin{tabular}{|c|c|c|c|c|c|c|c|c|c|c|c|}
\hline FH rank & 1 & 2 & 3 & 4 & 5 & 6 & 7 & 8 & 9 & 10 & D10-D1 \\
\hline \multicolumn{12}{|c|}{ Net Return } \\
\hline \multirow[t]{2}{*}{ Average } & 0.77 & 0.69 & 0.62 & 0.73 & 0.65 & 0.7 & 0.68 & 0.66 & 0.67 & 0.65 & $-0.11^{*}$ \\
\hline & $(2.46)$ & $(2.21)$ & $(2.00)$ & $(2.30)$ & $(2.10)$ & $(2.28)$ & (2.19) & $(2.10)$ & $(2.02)$ & (1.96) & $(-1.74)$ \\
\hline \multirow[t]{2}{*}{$\mathrm{CAPM} \alpha$} & 0.05 & -0.03 & -0.10 & 0.00 & -0.07 & -0.02 & -0.04 & -0.06 & -0.08 & -0.10 & $-0.15 * *$ \\
\hline & $(0.74)$ & $(-0.52)$ & $(-1.83)$ & $(0.04)$ & $(-1.4)$ & $(-0.32)$ & $(-0.72)$ & $(-1.14)$ & $(-1.4)$ & $(-1.49)$ & $(-2.22)$ \\
\hline \multirow[t]{2}{*}{ FF $\alpha$} & 0.01 & -0.05 & -0.12 & -0.02 & -0.08 & -0.04 & -0.06 & -0.07 & -0.07 & -0.07 & -0.08 \\
\hline & $(0.20)$ & $(-0.95)$ & $(-2.08)$ & $(-0.35)$ & $(-1.66)$ & $(-0.74)$ & $(-1.07)$ & $(-1.41)$ & $(-1.15)$ & $(-1.29)$ & $(-1.54)$ \\
\hline \multirow[t]{2}{*}{ Carhart $\alpha$} & 0.02 & -0.06 & -0.11 & -0.04 & -0.08 & -0.04 & -0.06 & -0.09 & -0.08 & -0.07 & -0.08 \\
\hline & $(0.25)$ & $(-1.04)$ & $(-1.94)$ & $(-0.67)$ & $(-1.43)$ & $(-0.69)$ & $(-1.07)$ & $(-1.6)$ & $(-1.28)$ & $(-1.16)$ & $(-1.53)$ \\
\hline \multirow[t]{2}{*}{$\operatorname{PS} \alpha$} & -0.01 & -0.08 & -0.15 & -0.05 & -0.09 & -0.06 & -0.09 & -0.10 & -0.08 & -0.07 & -0.06 \\
\hline & $(-0.09)$ & $(-1.31)$ & $(-2.78)$ & $(-0.93)$ & $(-1.77)$ & $(-1.06)$ & $(-1.58)$ & $(-1.81)$ & $(-1.31)$ & $(-1.2)$ & $(-1.16)$ \\
\hline \multicolumn{12}{|c|}{ Gross Return } \\
\hline \multirow[t]{2}{*}{ Average } & 0.87 & 0.79 & 0.72 & 0.83 & 0.75 & 0.79 & 0.78 & 0.76 & 0.76 & 0.76 & $-0.11^{*}$ \\
\hline & $(2.78)$ & $(2.51)$ & $(2.30)$ & $(2.60)$ & $(2.41)$ & $(2.60)$ & $(2.50)$ & $(2.41)$ & $(2.32)$ & $(2.27)$ & $(-1.70)$ \\
\hline CAPM $\alpha$ & $(2.27)$ & (1.09) & $(-0.08)$ & (1.69) & $(0.53)$ & (1.63) & $(1.06)$ & $(0.60)$ & $(0.33)$ & $(0.11)$ & $(-2.18)$ \\
\hline \multirow[t]{2}{*}{$\mathrm{FF} \alpha$} & 0.11 & 0.04 & -0.02 & 0.08 & 0.01 & 0.06 & 0.04 & 0.02 & 0.03 & 0.03 & -0.08 \\
\hline & $(1.82)$ & $(0.77)$ & $(-0.36)$ & $(1.46)$ & $(0.25)$ & (1.18) & $(0.77)$ & $(0.43)$ & $(0.57)$ & $(0.59)$ & $(-1.48)$ \\
\hline \multirow[t]{2}{*}{ Carhart $\alpha$} & 0.12 & 0.04 & -0.02 & 0.06 & 0.02 & 0.06 & 0.04 & 0.01 & 0.02 & 0.04 & -0.08 \\
\hline & (1.87) & $(0.61)$ & $(-0.28)$ & $(1.10)$ & $(0.37)$ & (1.11) & $(0.73)$ & $(0.12)$ & $(0.40)$ & $(0.67)$ & $(-1.48)$ \\
\hline \multirow[t]{2}{*}{$\operatorname{PS} \alpha$} & 0.09 & 0.02 & -0.05 & 0.04 & 0.00 & 0.04 & 0.01 & -0.01 & 0.02 & 0.03 & -0.06 \\
\hline & $(1.45)$ & $(0.35)$ & $(-1)$ & $(0.83)$ & $(0.03)$ & $(0.74)$ & $(0.18)$ & $(-0.13)$ & $(0.32)$ & $(0.56)$ & $(-1.11)$ \\
\hline
\end{tabular}


Table IA.IV (B)

Fund Herding Following a Smaller Crowd: Style Peers (II)

This table presents the performance of decile portfolios formed on the basis of $F H$, the average tendency of mutual funds to follow past institutional trades. $F H$ is constructed from the slope coefficient of cross-sectional regressions of mutual fund trades on past aggregate trades by their peer funds measured in the previous quarter, controlling for past stock returns, firm size, and the book-to-market ratio. Peer funds are identified by four styles from the Lipper mutual fund classification: Large-Cap Value, LargeCap growth, Small-Cap Value, and Small-Cap Growth. The return series span January 1990 to December 2009. Decile 10 is the portfolio of funds with the highest average herding measure. We compute monthly equally weighted net and gross (net plus expense ratio) returns on the portfolios, as well as risk-adjusted returns based on the CAPM, the Fama and French (1993, FF) three-factor model, the Carhart (1997) four-factor model, and the Pastor and Stambaugh (2003, PS) five-factor model. Average returns and alphas are in monthly percentages. Newey-West (1987) $t$-statistics are shown in parentheses. $* * *, * *$, and $*$ denote statistical significance at the $1 \%, 5 \%$, and $10 \%$ level, respectively, for the return differentials between deciles 10 and 1 .

\begin{tabular}{|c|c|c|c|c|c|c|c|c|c|c|c|}
\hline FH rank & 1 & 2 & 3 & 4 & 5 & 6 & 7 & 8 & 9 & 10 & D10-D1 \\
\hline \multicolumn{12}{|c|}{ Net Return } \\
\hline \multirow[t]{2}{*}{ Average } & 0.79 & 0.69 & 0.63 & 0.78 & 0.66 & 0.72 & 0.7 & 0.69 & 0.64 & 0.66 & $-0.13 *$ \\
\hline & $(2.43)$ & $(2.12)$ & $(1.95)$ & $(2.38)$ & $(2.03)$ & $(2.29)$ & $(2.15)$ & $(2.10)$ & (1.88) & (1.87) & $(-1.68)$ \\
\hline \multirow[t]{2}{*}{ CAPM $\alpha$} & 0.06 & -0.05 & -0.10 & 0.04 & -0.08 & -0.01 & -0.04 & -0.05 & -0.12 & -0.12 & $-0.17 * *$ \\
\hline & $(0.74)$ & $(-0.66)$ & $(-1.61)$ & $(0.64)$ & $(-1.4)$ & $(-0.11)$ & $(-0.64)$ & $(-0.79)$ & $(-1.77)$ & $(-1.45)$ & $(-2.15)$ \\
\hline \multirow[t]{2}{*}{$\mathrm{FF} \alpha$} & 0.02 & -0.06 & -0.11 & 0.02 & -0.09 & -0.02 & -0.05 & -0.05 & -0.1 & -0.08 & -0.09 \\
\hline & $(0.28)$ & $(-0.93)$ & $(-1.77)$ & $(0.39)$ & $(-1.57)$ & $(-0.35)$ & $(-0.85)$ & $(-0.88)$ & $(-1.5)$ & $(-1.15)$ & $(-1.47)$ \\
\hline \multirow[t]{2}{*}{ Carhart $\alpha$} & 0.03 & -0.07 & -0.11 & 0.00 & -0.10 & -0.02 & -0.05 & -0.08 & -0.11 & -0.06 & -0.09 \\
\hline & $(0.38)$ & $(-0.96)$ & $(-1.64)$ & $(0.07)$ & $(-1.63)$ & $(-0.32)$ & $(-0.78)$ & $(-1.2)$ & $(-1.57)$ & $(-0.91)$ & $(-1.41)$ \\
\hline \multirow[t]{2}{*}{$\operatorname{PS} \alpha$} & 0.01 & -0.09 & -0.15 & -0.01 & -0.12 & -0.06 & -0.08 & -0.10 & -0.11 & -0.06 & -0.07 \\
\hline & $(0.13)$ & $(-1.35)$ & $(-2.35)$ & $(-0.21)$ & $(-2.12)$ & $(-0.98)$ & $(-1.25)$ & $(-1.44)$ & $(-1.68)$ & $(-0.88)$ & $(-1.09)$ \\
\hline \multicolumn{12}{|c|}{ Gross Return } \\
\hline \multirow[t]{2}{*}{ Average } & 0.89 & 0.79 & 0.73 & 0.87 & 0.76 & 0.81 & 0.79 & 0.79 & 0.74 & 0.76 & $-0.13 *$ \\
\hline & $(2.75)$ & $(2.42)$ & $(2.25)$ & $(2.67)$ & $(2.33)$ & $(2.59)$ & $(2.45)$ & $(2.40)$ & $(2.17)$ & $(2.16)$ & $(-1.65)$ \\
\hline $\mathrm{CAPM} \alpha$ & $(2.10)$ & $(0.69)$ & $(-0.12)$ & $(2.22)$ & $(0.29)$ & $(1.55)$ & $(0.89)$ & $(0.70)$ & $(-0.29)$ & $(-0.15)$ & $(-2.12)$ \\
\hline \multirow[t]{2}{*}{$\mathrm{FF} \alpha$} & 0.12 & 0.03 & -0.01 & 0.12 & 0.01 & 0.08 & 0.04 & 0.04 & 0 & 0.03 & -0.09 \\
\hline & $(1.75)$ & $(0.51)$ & $(-0.23)$ & $(2.14)$ & $(0.09)$ & $(1.25)$ & $(0.72)$ & $(0.74)$ & $(0.01)$ & $(0.43)$ & $(-1.44)$ \\
\hline \multirow[t]{2}{*}{ Carhart $\alpha$} & 0.13 & 0.03 & -0.01 & 0.10 & 0.00 & 0.08 & 0.05 & 0.02 & -0.01 & 0.04 & -0.09 \\
\hline & $(1.83)$ & $(0.43)$ & $(-0.18)$ & $(1.79)$ & $(-0.07)$ & $(1.18)$ & $(0.71)$ & $(0.32)$ & $(-0.11)$ & $(0.63)$ & $(-1.38)$ \\
\hline \multirow[t]{2}{*}{ PS $\alpha$} & 0.11 & 0.00 & -0.05 & 0.08 & -0.03 & 0.04 & 0.02 & 0.00 & -0.01 & 0.04 & -0.07 \\
\hline & $(1.52)$ & $(0.05)$ & $(-0.81)$ & $(1.49)$ & $(-0.49)$ & $(0.63)$ & $(0.27)$ & $(0.04)$ & $(-0.22)$ & $(0.62)$ & $(-1.06)$ \\
\hline
\end{tabular}


Table IA.IV (C)

Fund Herding Following a Smaller Crowd: Style Peers (III)

This table presents the performance of decile portfolios formed on the basis of $F H$, the average tendency of mutual funds to follow past institutional trades. FH is constructed from the slope coefficient of cross-sectional regressions of mutual fund trades on past aggregate trades by their peer funds measured in the previous quarter, controlling for past stock returns, firm size, and the book-to-market ratio. Peer funds are defined by three styles following the Thomson Reuters mutual fund investment objective code: Aggressive Growth, Growth, and Growth and Income. The return series span January 1990 to December 2009 . Decile 10 is the portfolio of funds with the highest average herding measure. We compute monthly equally weighted net and gross (net plus expense ratio) returns on the portfolios, as well as risk-adjusted returns based on the CAPM, the Fama and French (1993, FF) three-factor model, the Carhart (1997) four-factor model, and the Pastor and Stambaugh (2003, PS) five-factor model. Average returns and alphas are in monthly percentages. Newey-West (1987) $t$-statistics are shown in parentheses. $* * *, * *$, and $*$ denote statistical significance at the $1 \%, 5 \%$, and $10 \%$ level, respectively, for the return differentials between deciles 10 and 1

\begin{tabular}{|c|c|c|c|c|c|c|c|c|c|c|c|}
\hline FH rank & 1 & 2 & 3 & 4 & 5 & 6 & 7 & 8 & 9 & 10 & D10-D1 \\
\hline \multicolumn{12}{|c|}{ Net Return } \\
\hline \multirow{2}{*}{ Average } & 0.82 & 0.77 & 0.82 & 0.8 & 0.73 & 0.75 & 0.79 & 0.71 & 0.73 & 0.72 & -0.10 \\
\hline & $(2.83)$ & $(2.65)$ & $(2.90)$ & $(2.82)$ & $(2.53)$ & $(2.62)$ & $(2.69)$ & $(2.43)$ & $(2.42)$ & $(2.39)$ & $(-1.61)$ \\
\hline \multirow[t]{2}{*}{$\mathrm{CAPM} \alpha$} & 0.06 & 0.00 & 0.07 & 0.05 & -0.03 & -0.01 & 0.02 & -0.06 & -0.06 & -0.06 & $-0.12 *$ \\
\hline & $(0.83)$ & $(0.05)$ & $(1.02)$ & $(0.72)$ & $(-0.52)$ & $(-0.2)$ & $(0.31)$ & $(-1.14)$ & $(-1.06)$ & $(-1.09)$ & $(-1.89)$ \\
\hline \multirow[t]{2}{*}{$\mathrm{FF} \alpha$} & 0.00 & -0.05 & 0.01 & -0.01 & -0.09 & -0.06 & -0.02 & -0.09 & -0.07 & -0.07 & -0.06 \\
\hline & $(-0.06)$ & $(-0.96)$ & $(0.11)$ & $(-0.28)$ & $(-1.74)$ & $(-1.28)$ & $(-0.37)$ & $(-1.69)$ & $(-1.47)$ & $(-1.27)$ & $(-1.12)$ \\
\hline \multirow[t]{2}{*}{ Carhart $\alpha$} & 0.01 & -0.05 & 0.01 & -0.01 & -0.08 & -0.06 & -0.02 & -0.09 & -0.09 & -0.08 & -0.09 \\
\hline & $(0.18)$ & $(-0.87)$ & $(0.16)$ & $(-0.1)$ & $(-1.41)$ & $(-1.11)$ & $(-0.36)$ & $(-1.64)$ & $(-1.71)$ & $(-1.41)$ & $(-1.60)$ \\
\hline \multirow[t]{2}{*}{ PS $\alpha$} & -0.01 & -0.08 & -0.01 & -0.02 & -0.10 & -0.08 & -0.03 & -0.11 & -0.1 & -0.08 & -0.07 \\
\hline & $(-0.24)$ & $(-1.36)$ & $(-0.22)$ & $(-0.37)$ & $(-1.78)$ & $(-1.48)$ & $(-0.63)$ & $(-1.98)$ & $(-1.85)$ & $(-1.42)$ & $(-1.21)$ \\
\hline \multicolumn{12}{|c|}{ Gross Return } \\
\hline \multirow[t]{2}{*}{ Average } & 0.93 & 0.87 & 0.93 & 0.9 & 0.83 & 0.85 & 0.89 & 0.81 & 0.83 & 0.83 & $-0.10 *$ \\
\hline & $(3.20)$ & $(3.01)$ & $(3.25)$ & $(3.17)$ & $(2.87)$ & $(2.96)$ & $(3.02)$ & $(2.76)$ & $(2.76)$ & $(2.74)$ & $(-1.67)$ \\
\hline $\mathrm{CAPM} \alpha$ & (2.39) & $(1.70)$ & $(2.53)$ & $(2.29)$ & $(0.99)$ & $(1.48)$ & (2.03) & $(0.68)$ & $(0.78)$ & $(0.68)$ & $(-1.95)$ \\
\hline \multirow[t]{2}{*}{$\mathrm{FF} \alpha$} & 0.10 & 0.05 & 0.11 & 0.09 & 0.01 & 0.03 & 0.08 & 0.01 & 0.03 & 0.04 & -0.07 \\
\hline & $(1.82)$ & $(1.01)$ & (2.13) & $(1.70)$ & $(0.12)$ & $(0.68)$ & (1.58) & $(0.24)$ & $(0.52)$ & $(0.69)$ & $(-1.19)$ \\
\hline \multirow[t]{2}{*}{ Carhart $\alpha$} & 0.12 & 0.05 & 0.11 & 0.09 & 0.02 & 0.04 & 0.08 & 0.01 & 0.01 & 0.03 & $-0.09 *$ \\
\hline & $(2.00)$ & $(1.00)$ & (2.09) & (1.79) & $(0.29)$ & $(0.76)$ & (1.41) & $(0.16)$ & $(0.17)$ & $(0.47)$ & $(-1.66)$ \\
\hline \multirow[t]{2}{*}{$\operatorname{PS} \alpha$} & 0.09 & 0.03 & 0.09 & 0.08 & 0.00 & 0.02 & 0.06 & -0.01 & 0.00 & 0.02 & -0.07 \\
\hline & $(1.65)$ & $(0.50)$ & (1.69) & $(1.50)$ & $(-0.04)$ & $(0.35)$ & (1.14) & $(-0.17)$ & $(0.07)$ & $(0.40)$ & $(-1.27)$ \\
\hline
\end{tabular}




\section{Table IA.V}

\section{Fund Herding from Trades Including Initiations and Deletions}

This table presents the performance of decile portfolios formed on the basis of $F H$, the average tendency of mutual funds to follow past institutional trades. $F H$ is constructed from the slope coefficient of cross-sectional regressions of mutual fund trades on past aggregate institutional trades measured in the previous quarter, controlling for past stock returns, firm size, and the book-to-market ratio. All trades, including deletions and initiations, are used in the calculation of a fund's herding tendency. The return series span January 1990 to December 2009. Decile 10 is the portfolio of funds with the highest fund herding measure. We compute monthly equally weighted net and gross (net plus expense ratio) returns on the portfolios, as well as risk-adjusted returns based on the CAPM, the Fama and French (1993, FF) three-factor model, the Carhart (1997) four-factor model, and the Pastor and Stambaugh (2003, PS) five-factor model. Average returns and alphas are in monthly percentages. Newey-West (1987) $t$ statistics are in parentheses. $* * *, * *$, and $*$ denote statistical significance at the $1 \%, 5 \%$, and $10 \%$ level, respectively, for the return differentials between deciles 10 and 1.

\begin{tabular}{|c|c|c|c|c|c|c|c|c|c|c|c|}
\hline FH rank & 1 & 2 & 3 & 4 & 5 & 6 & 7 & 8 & 9 & 10 & D10-D1 \\
\hline \multicolumn{12}{|c|}{ Net Return } \\
\hline \multirow[t]{2}{*}{ Average } & 0.91 & 0.87 & 0.89 & 0.91 & 0.88 & 0.81 & 0.83 & 0.86 & 0.81 & 0.76 & $-0.15 * * *$ \\
\hline & $(3.59)$ & (3.37) & $(3.37)$ & $(3.55)$ & (3.39) & (3.11) & $(3.23)$ & $(3.25)$ & (3.03) & $(2.89)$ & $(-3.18)$ \\
\hline \multirow[t]{2}{*}{ CAPM $\alpha$} & 0.02 & -0.03 & -0.03 & 0.01 & -0.03 & -0.10 & -0.07 & -0.06 & -0.11 & -0.15 & $-0.17 * * *$ \\
\hline & $(0.33)$ & $(-0.55)$ & $(-0.45)$ & $(0.22)$ & $(-0.65)$ & $(-2.05)$ & $(-1.58)$ & $(-1.12)$ & $(-2.11)$ & $(-2.97)$ & $(-3.73)$ \\
\hline \multirow[t]{2}{*}{$\mathrm{FF} \alpha$} & 0.00 & -0.05 & -0.05 & -0.02 & -0.05 & -0.12 & -0.09 & -0.06 & -0.10 & -0.15 & $-0.15 * * *$ \\
\hline & $(-0.09)$ & $(-1.13)$ & $(-1.2)$ & $(-0.43)$ & $(-1.46)$ & $(-2.98)$ & $(-2.24)$ & $(-1.43)$ & $(-2.09)$ & $(-3.1)$ & $(-3.34)$ \\
\hline \multirow[t]{2}{*}{ Carhart $\alpha$} & 0.00 & -0.05 & -0.06 & -0.02 & -0.06 & -0.10 & -0.08 & -0.06 & -0.10 & -0.14 & $-0.14 * * *$ \\
\hline & $(0.02)$ & $(-1.02)$ & $(-1.3)$ & $(-0.5)$ & $(-1.51)$ & $(-2.59)$ & $(-1.72)$ & $(-1.16)$ & $(-1.92)$ & $(-2.46)$ & $(-3.02)$ \\
\hline \multirow[t]{2}{*}{$\operatorname{PS} \alpha$} & -0.01 & -0.06 & -0.07 & -0.03 & -0.06 & -0.10 & -0.08 & -0.05 & -0.10 & -0.14 & $-0.13 * * *$ \\
\hline & $(-0.23)$ & $(-1.19)$ & $(-1.35)$ & $(-0.63)$ & $(-1.41)$ & $(-2.48)$ & $(-1.71)$ & $(-1.09)$ & $(-1.89)$ & $(-2.51)$ & $(-2.73)$ \\
\hline \multicolumn{12}{|c|}{ Gross Return } \\
\hline \multirow[t]{2}{*}{ Average } & 1.02 & 0.97 & 0.98 & 1.01 & 0.97 & 0.91 & 0.93 & 0.96 & 0.91 & 0.87 & $-0.15^{* * *}$ \\
\hline & $(4.02)$ & $(3.76)$ & $(3.74)$ & $(3.91)$ & $(3.74)$ & $(3.47)$ & $(3.59)$ & $(3.62)$ & $(3.40)$ & $(3.28)$ & $(-3.26)$ \\
\hline CAPM $\alpha$ & $(2.13)$ & $(1.18)$ & $(1.25)$ & $(1.88)$ & $(1.30)$ & $(-0.11)$ & $(0.43)$ & $(0.78)$ & $(-0.22)$ & $(-0.95)$ & $(-3.82)$ \\
\hline \multirow[t]{2}{*}{$\mathrm{FF} \alpha$} & 0.10 & 0.05 & 0.04 & 0.07 & 0.04 & -0.02 & 0.00 & 0.03 & 0.00 & -0.05 & $-0.15 * * *$ \\
\hline & $(2.02)$ & $(0.94)$ & $(0.92)$ & $(1.68)$ & $(1.00)$ & $(-0.59)$ & $(-0.02)$ & $(0.74)$ & $(-0.01)$ & $(-0.95)$ & $(-3.43)$ \\
\hline \multirow[t]{2}{*}{ Carhart $\alpha$} & 0.11 & 0.05 & 0.03 & 0.07 & 0.03 & -0.01 & 0.02 & 0.04 & 0.00 & -0.03 & $-0.14 * * *$ \\
\hline & (1.97) & $(0.99)$ & $(0.69)$ & $(1.51)$ & $(0.84)$ & $(-0.27)$ & $(0.38)$ & $(0.86)$ & $(0.08)$ & $(-0.58)$ & $(-3.11)$ \\
\hline \multirow[t]{2}{*}{$\operatorname{PS} \alpha$} & 0.10 & 0.04 & 0.03 & 0.06 & 0.03 & -0.01 & 0.02 & 0.04 & 0.00 & -0.03 & $-0.13 * * *$ \\
\hline & $(1.72)$ & $(0.78)$ & $(0.63)$ & $(1.36)$ & $(0.83)$ & $(-0.25)$ & $(0.36)$ & $(0.89)$ & $(0.03)$ & $(-0.62)$ & $(-2.81)$ \\
\hline
\end{tabular}


Table IA.VI

Fund Herding from Trades Measured as Changes in Portfolio Weights

This table presents the performance of decile portfolios formed on the basis of $F H$, the average tendency of mutual funds to follow past institutional trades. FH is constructed from the slope coefficient of cross-sectional regressions of mutual fund trades (measured as changes in portfolio weights) on past aggregate institutional trades measured in the previous quarter, controlling for past stock returns, firm size, and the book-to-market ratio. The return series span January 1990 to December 2009 . Decile 10 is the portfolio of funds with the highest average herding measure. We compute monthly equally weighted net and gross (net plus expense ratio) returns, as well as risk-adjusted returns based on the CAPM, the Fama and French (1993, FF) three-factor model, the Carhart (1997) four-factor model, and the Pastor and Stambaugh (2003, PS) fivefactor model. Average returns and alphas are in monthly percentages. Newey-West (1987) $t$-statistics are shown in parentheses. ***,**, and * denote statistical significance at the $1 \%, 5 \%$, and $10 \%$ level, respectively, for the return differentials between deciles 10 and 1 .

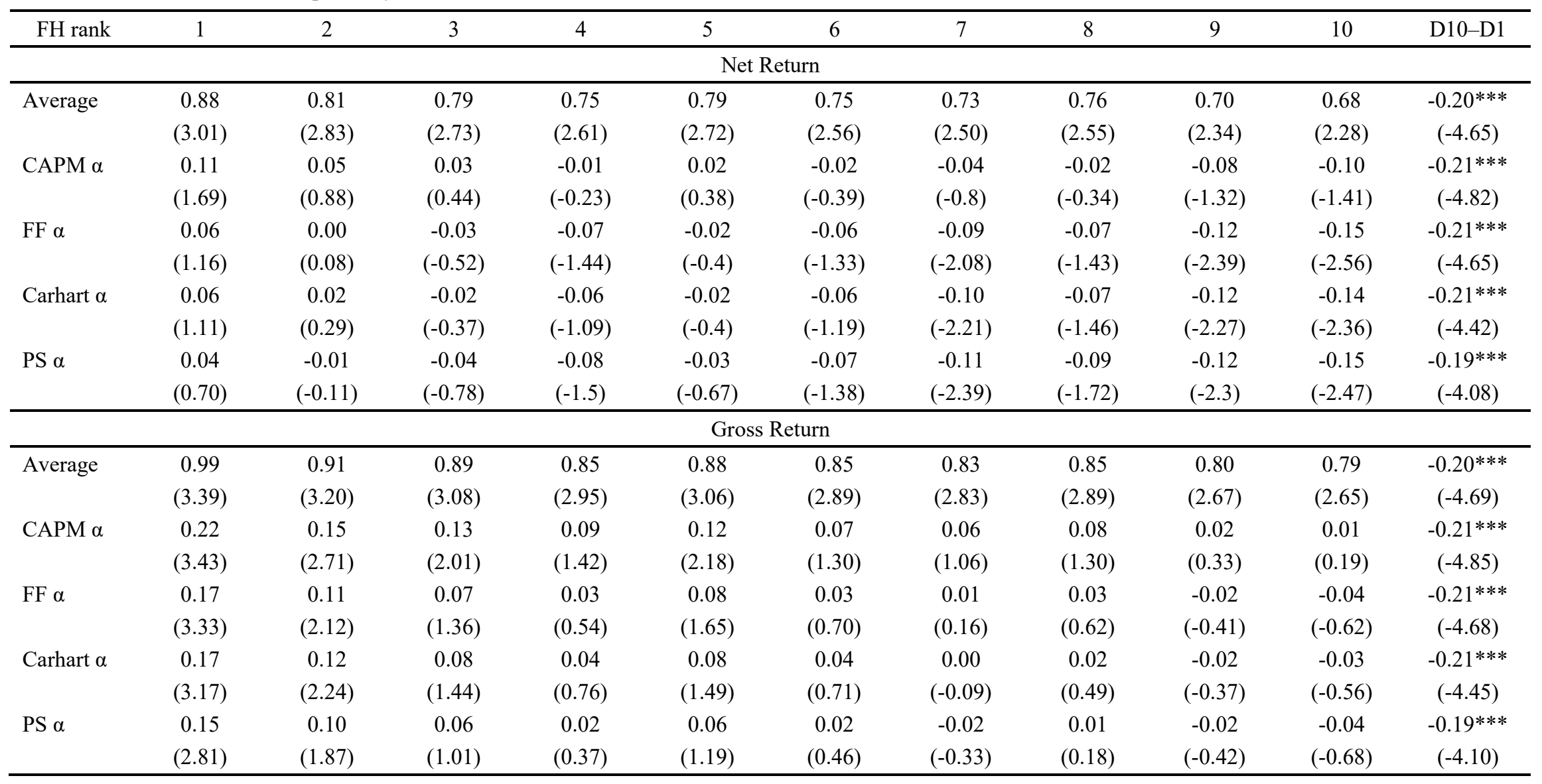




\section{Table IA.VII}

\section{Fund Herding Controlling for Industry Momentum}

This table presents the performance of decile portfolios formed on the basis of $F H$, the average tendency of mutual funds to follow past institutional trades. FH is constructed from cross-sectional regressions of mutual fund trades on past aggregate institutional trades, controlling for past stock returns, firm size, book-to-market, and industry momentum. The portfolios are formed at the end of each quarter from 1989Q4 to 2009Q3 and held for one quarter. The return series span January 1990 to December 2009. Decile 10 is the portfolio of funds with the highest fund herding measure. We compute monthly equally-weighted net and gross (net plus expense ratio) returns on the portfolios, as well as risk-adjusted returns based on the CAPM, the Fama and French (1993, FF) three-factor model, the Carhart (1997) four-factor model, and the Pastor and Stambaugh (2003, PS) five-factor model. Average returns and alphas are in monthly percentages. Newey-West (1987) $t$-statistics are shown in parentheses. ***,**, and $*$ denote statistical significance at the $1 \%, 5 \%$, and $10 \%$ level, respectively, for the return differentials between deciles 10 and 1 .

\begin{tabular}{|c|c|c|c|c|c|c|c|c|c|c|c|}
\hline FH rank & 1 & 2 & 3 & 4 & 5 & 6 & 7 & 8 & 9 & 10 & D10-D1 \\
\hline \multicolumn{12}{|c|}{ Net Return } \\
\hline \multirow[t]{2}{*}{ Average } & 0.83 & 0.82 & 0.80 & 0.77 & 0.80 & 0.74 & 0.76 & 0.76 & 0.71 & 0.64 & $-0.19 * * *$ \\
\hline & $(2.88)$ & $(2.84)$ & $(2.77)$ & $(2.67)$ & $(2.80)$ & $(2.53)$ & $(2.61)$ & $(2.53)$ & $(2.34)$ & $(2.13)$ & $(-3.41)$ \\
\hline \multirow[t]{2}{*}{ CAPM $\alpha$} & 0.07 & 0.06 & 0.04 & 0.01 & 0.04 & -0.03 & -0.01 & -0.03 & -0.08 & -0.15 & $-0.22 * * *$ \\
\hline & $(0.98)$ & $(0.84)$ & $(0.59)$ & $(0.08)$ & $(0.68)$ & $(-0.62)$ & $(-0.22)$ & $(-0.46)$ & $(-1.33)$ & $(-2.54)$ & $(-3.78)$ \\
\hline \multirow[t]{2}{*}{$\mathrm{FF} \alpha$} & 0.01 & -0.01 & -0.02 & -0.05 & -0.02 & -0.08 & -0.05 & -0.06 & -0.11 & -0.17 & $-0.17 * * *$ \\
\hline & $(0.12)$ & $(-0.12)$ & $(-0.35)$ & $(-1.06)$ & $(-0.41)$ & $(-1.81)$ & $(-1.19)$ & $(-1.29)$ & $(-1.97)$ & $(-3.13)$ & $(-3.27)$ \\
\hline \multirow[t]{2}{*}{ Carhart $\alpha$} & 0.01 & -0.01 & -0.03 & -0.05 & -0.02 & -0.08 & -0.05 & -0.05 & -0.11 & -0.16 & $-0.17 * * *$ \\
\hline & $(0.15)$ & $(-0.1)$ & $(-0.66)$ & $(-0.92)$ & $(-0.4)$ & $(-1.65)$ & $(-0.97)$ & $(-0.97)$ & $(-1.88)$ & $(-2.74)$ & $(-3.04)$ \\
\hline \multirow[t]{2}{*}{$\operatorname{PS} \alpha$} & -0.01 & -0.03 & -0.05 & -0.07 & -0.03 & -0.08 & -0.05 & -0.06 & -0.12 & -0.17 & $-0.15 * * *$ \\
\hline & $(-0.2)$ & $(-0.47)$ & $(-1.11)$ & $(-1.34)$ & $(-0.62)$ & $(-1.8)$ & $(-1.05)$ & $(-1.03)$ & $(-1.99)$ & $(-2.89)$ & $(-2.71)$ \\
\hline \multicolumn{12}{|c|}{ Gross Return } \\
\hline \multirow[t]{2}{*}{ Average } & 0.94 & 0.92 & 0.91 & 0.87 & 0.90 & 0.83 & 0.85 & 0.86 & 0.81 & 0.75 & $-0.19^{* * *}$ \\
\hline & (3.26) & (3.19) & (3.12) & $(3.01)$ & (3.14) & $(2.87)$ & $(2.95)$ & $(2.87)$ & $(2.68)$ & (2.49) & $(-3.44)$ \\
\hline $\mathrm{CAPM} \alpha$ & $(2.54)$ & $(2.36)$ & $(2.13)$ & $(1.68)$ & $(2.34)$ & $(1.15)$ & $(1.58)$ & $(1.34)$ & $(0.39)$ & $(-0.65)$ & $(-3.81)$ \\
\hline \multirow[t]{2}{*}{$\mathrm{FF} \alpha$} & 0.12 & 0.10 & 0.08 & 0.05 & 0.08 & 0.01 & 0.04 & 0.04 & 0.00 & -0.06 & $-0.17 * * *$ \\
\hline & $(2.01)$ & $(1.71)$ & $(1.70)$ & $(0.93)$ & (1.69) & $(0.32)$ & $(0.96)$ & $(0.71)$ & $(-0.07)$ & $(-1.08)$ & $(-3.30)$ \\
\hline \multirow[t]{2}{*}{ Carhart $\alpha$} & 0.12 & 0.10 & 0.07 & 0.05 & 0.08 & 0.02 & 0.05 & 0.05 & -0.01 & -0.05 & $-0.17 * * *$ \\
\hline & (1.89) & $(1.62)$ & $(1.32)$ & $(0.95)$ & $(1.57)$ & $(0.43)$ & (1.07) & $(0.96)$ & $(-0.11)$ & $(-0.87)$ & $(-3.06)$ \\
\hline \multirow[t]{2}{*}{$\operatorname{PS} \alpha$} & 0.10 & 0.07 & 0.05 & 0.03 & 0.07 & 0.01 & 0.05 & 0.04 & -0.01 & -0.06 & $-0.16^{* * *}$ \\
\hline & $(1.60)$ & $(1.25)$ & $(0.92)$ & $(0.56)$ & $(1.28)$ & $(0.25)$ & $(0.93)$ & $(0.83)$ & $(-0.24)$ & $(-1.02)$ & $(-2.73)$ \\
\hline
\end{tabular}




\section{Table IA.VIII}

\section{Fund Herding Controlling for Contemporaneous Institutional Trades}

This table presents the performance of decile portfolios formed on the basis of $F H$, the average tendency of mutual funds to follow past institutional trades. FH is constructed from the slope coefficient of cross-sectional regressions of mutual fund trades on aggregate institutional trades measured in the previous quarter, controlling for past stock returns, firm size, the book-to-market ratio, and contemporaneous aggregate institutional trades. The return series span January 1990 to December 2009 . Decile 10 is the portfolio of funds with the highest fund herding measure. We compute monthly equally-weighted net and gross (net plus expense ratio) returns on the portfolios, as well as risk-adjusted returns based on the CAPM, the Fama and French (1993, FF) three-factor model, the Carhart (1997) four-factor model, and the Pastor and Stambaugh (2003, PS) five-factor model. Average returns and alphas are in monthly percentages. Newey-West (1987) $t$-statistics are shown in parentheses. $* * * * *$, and $*$ denote statistical significance at the $1 \%, 5 \%$, and $10 \%$ level, respectively, for the return differentials between deciles 10 and 1 .

\begin{tabular}{|c|c|c|c|c|c|c|c|c|c|c|c|}
\hline FH rank & 1 & 2 & 3 & 4 & 5 & 6 & 7 & 8 & 9 & 10 & D10-D1 \\
\hline \multicolumn{12}{|c|}{ Net Return } \\
\hline \multirow[t]{2}{*}{ Average } & 0.81 & 0.75 & 0.77 & 0.76 & 0.78 & 0.76 & 0.81 & 0.73 & 0.75 & 0.66 & $-0.16^{* *}$ \\
\hline & $(2.88)$ & $(2.60)$ & $(2.68)$ & $(2.66)$ & $(2.71)$ & $(2.58)$ & $(2.70)$ & $(2.41)$ & $(2.46)$ & $(2.18)$ & $(-2.39)$ \\
\hline \multirow[t]{2}{*}{ CAPM $\alpha$} & 0.06 & -0.01 & 0.01 & 0.00 & 0.02 & -0.01 & 0.03 & -0.05 & -0.04 & -0.13 & $-0.19 * * *$ \\
\hline & $(0.91)$ & $(-0.22)$ & $(0.17)$ & $(0.06)$ & $(0.27)$ & $(-0.24)$ & $(0.45)$ & $(-0.74)$ & $(-0.65)$ & $(-2.08)$ & $(-2.98)$ \\
\hline \multirow[t]{2}{*}{$\mathrm{FF} \alpha$} & 0.00 & -0.07 & -0.04 & -0.05 & -0.04 & -0.06 & -0.01 & -0.09 & -0.07 & -0.15 & $-0.15 * *$ \\
\hline & $(-0.02)$ & $(-1.27)$ & $(-0.74)$ & $(-0.97)$ & $(-0.91)$ & $(-1.24)$ & $(-0.27)$ & $(-1.63)$ & $(-1.15)$ & $(-2.52)$ & $(-2.43)$ \\
\hline \multirow[t]{2}{*}{ Carhart $\alpha$} & 0.01 & -0.06 & -0.05 & -0.05 & -0.04 & -0.08 & -0.03 & -0.10 & -0.05 & -0.15 & $-0.16^{* * *}$ \\
\hline & $(0.17)$ & $(-1.05)$ & $(-0.80)$ & $(-0.87)$ & $(-0.86)$ & $(-1.52)$ & $(-0.50)$ & $(-1.70)$ & $(-0.80)$ & $(-2.36)$ & $(-2.70)$ \\
\hline \multirow[t]{2}{*}{$\operatorname{PS} \alpha$} & -0.01 & -0.09 & -0.07 & -0.06 & -0.06 & -0.10 & -0.03 & -0.11 & -0.05 & -0.15 & $-0.14 * *$ \\
\hline & $(-0.17)$ & $(-1.61)$ & $(-1.21)$ & $(-1.11)$ & $(-1.12)$ & $(-1.94)$ & $(-0.66)$ & $(-1.85)$ & $(-0.85)$ & $(-2.39)$ & $(-2.31)$ \\
\hline \multicolumn{12}{|c|}{ Gross Return } \\
\hline \multirow[t]{2}{*}{ Average } & 0.92 & 0.85 & 0.87 & 0.86 & 0.88 & 0.85 & 0.91 & 0.83 & 0.85 & 0.76 & $-0.16^{* *}$ \\
\hline & $(3.25)$ & $(2.95)$ & $(3.03)$ & $(3.00)$ & $(3.05)$ & $(2.91)$ & $(3.02)$ & $(2.73)$ & $(2.80)$ & $(2.53)$ & $(-2.37)$ \\
\hline $\mathrm{CAPM} \alpha$ & $(2.47)$ & $(1.37)$ & $(1.58)$ & $(1.59)$ & $(1.85)$ & $(1.34)$ & $(2.02)$ & $(0.66)$ & $(0.98)$ & $(-0.35)$ & $(-2.97)$ \\
\hline \multirow[t]{2}{*}{$\mathrm{FF} \alpha$} & 0.10 & 0.03 & 0.06 & 0.05 & 0.05 & 0.04 & 0.08 & 0.01 & 0.04 & -0.04 & $-0.14 * *$ \\
\hline & $(1.70)$ & $(0.54)$ & $(1.00)$ & $(0.91)$ & $(1.06)$ & $(0.75)$ & $(1.67)$ & $(0.12)$ & $(0.62)$ & $(-0.7)$ & $(-2.41)$ \\
\hline \multirow[t]{2}{*}{ Carhart $\alpha$} & 0.12 & 0.04 & 0.05 & 0.05 & 0.05 & 0.02 & 0.07 & 0.00 & 0.05 & -0.04 & $-0.16 * * *$ \\
\hline & $(1.82)$ & $(0.75)$ & $(0.88)$ & $(0.98)$ & $(1.03)$ & $(0.44)$ & $(1.39)$ & $(-0.02)$ & $(0.80)$ & $(-0.66)$ & $(-2.68)$ \\
\hline \multirow[t]{2}{*}{$\operatorname{PS} \alpha$} & 0.09 & 0.01 & 0.03 & 0.04 & 0.04 & 0.00 & 0.06 & -0.01 & 0.05 & -0.04 & $-0.14 * *$ \\
\hline & $(1.50)$ & $(0.27)$ & $(0.45)$ & $(0.68)$ & $(0.78)$ & $(-0.01)$ & $(1.18)$ & $(-0.22)$ & $(0.73)$ & $(-0.68)$ & $(-2.30)$ \\
\hline
\end{tabular}


Table IA.IX

Fund Herding from Trade Regressions without Control Variables

This table presents the performance of decile portfolios formed on the basis of Fund Herding $(F H)$, the average tendency of mutual funds to follow past institutional trades. FH is constructed from the slope coefficient of cross-sectional regressions of mutual fund trades on past aggregate institutional trades measured in the previous quarter, without controlling for stock characteristics. The return series span January 1990 to December 2009. Decile 10 is the portfolio of funds with the highest average herding measure. We compute monthly equally weighted net and gross (net plus expense ratio) returns, as well as risk-adjusted returns based on the CAPM, the Fama and French $(1993$, FF) three-factor model, the Carhart (1997) four-factor model, and the Pastor and Stambaugh (2003, PS) five-factor model. Average returns and alphas are in monthly percentages. Newey-West (1987) $t$-statistics are shown in parentheses. $* * * * *$, and $*$ denote statistical significance at the $1 \%, 5 \%$, and $10 \%$ level, respectively, for the return differentials between deciles 10 and 1 .

\begin{tabular}{|c|c|c|c|c|c|c|c|c|c|c|c|}
\hline FH rank & 1 & 2 & 3 & 4 & 5 & 6 & 7 & 8 & 9 & 10 & D10-D1 \\
\hline \multicolumn{12}{|c|}{ Net Return } \\
\hline \multirow[t]{2}{*}{ Average } & 0.79 & 0.81 & 0.78 & 0.78 & 0.78 & 0.72 & 0.80 & 0.69 & 0.73 & 0.64 & $-0.14 * *$ \\
\hline & $(2.82)$ & $(2.87)$ & $(2.74)$ & $(2.75)$ & $(2.72)$ & $(2.48)$ & $(2.71)$ & $(2.31)$ & $(2.37)$ & $(2.18)$ & $(-1.98)$ \\
\hline \multirow[t]{2}{*}{$\mathrm{CAPM} \alpha$} & 0.05 & 0.06 & 0.02 & 0.02 & 0.02 & -0.05 & 0.02 & -0.09 & -0.06 & -0.13 & $-0.17 * *$ \\
\hline & $(0.55)$ & $(0.85)$ & $(0.36)$ & $(0.35)$ & $(0.30)$ & $(-0.8)$ & $(0.37)$ & $(-1.49)$ & $(-0.92)$ & $(-1.69)$ & $(-2.39)$ \\
\hline \multirow[t]{2}{*}{$\mathrm{FF} \alpha$} & -0.04 & -0.03 & -0.05 & -0.05 & -0.04 & -0.10 & -0.02 & -0.11 & -0.06 & -0.14 & -0.10 \\
\hline & $(-0.57)$ & $(-0.52)$ & $(-0.82)$ & $(-0.97)$ & $(-0.85)$ & $(-2.14)$ & $(-0.33)$ & $(-2.24)$ & $(-1.09)$ & $(-2.04)$ & $(-1.61)$ \\
\hline \multirow[t]{2}{*}{ Carhart $\alpha$} & -0.03 & -0.02 & -0.04 & -0.04 & -0.04 & -0.10 & -0.01 & -0.12 & -0.07 & -0.15 & $-0.12^{*}$ \\
\hline & $(-0.37)$ & $(-0.35)$ & $(-0.6)$ & $(-0.81)$ & $(-0.81)$ & $(-2.09)$ & $(-0.13)$ & $(-2.22)$ & $(-1.18)$ & $(-1.92)$ & $(-1.80)$ \\
\hline \multirow[t]{2}{*}{ PS $\alpha$} & -0.06 & -0.04 & -0.05 & -0.07 & -0.06 & -0.12 & -0.02 & -0.13 & -0.07 & -0.17 & $-0.11 *$ \\
\hline & $(-0.89)$ & $(-0.8)$ & $(-0.86)$ & $(-1.29)$ & $(-1.1)$ & $(-2.4)$ & $(-0.35)$ & $(-2.44)$ & $(-1.19)$ & $(-2.22)$ & $(-1.66)$ \\
\hline \multicolumn{12}{|c|}{ Gross Return } \\
\hline \multirow[t]{2}{*}{ Average } & 0.91 & 0.92 & 0.88 & 0.88 & 0.88 & 0.82 & 0.90 & 0.79 & 0.84 & 0.76 & $-0.15^{* *}$ \\
\hline & $(3.25)$ & $(3.25)$ & $(3.11)$ & $(3.11)$ & $(3.08)$ & $(2.83)$ & $(3.05)$ & $(2.66)$ & $(2.72)$ & $(2.56)$ & $(-2.06)$ \\
\hline $\mathrm{CAPM} \alpha$ & (1.97) & $(2.42)$ & (1.95) & (1.98) & (1.95) & $(0.85)$ & (1.97) & $(0.20)$ & $(0.63)$ & $(-0.17)$ & $(-2.47)$ \\
\hline \multirow[t]{2}{*}{$\mathrm{FF} \alpha$} & 0.08 & 0.08 & 0.06 & 0.05 & 0.06 & 0.00 & 0.08 & -0.01 & 0.04 & -0.03 & $-0.11^{*}$ \\
\hline & $(1.11)$ & $(1.57)$ & $(1.02)$ & $(1.01)$ & $(1.20)$ & $(-0.03)$ & $(1.53)$ & $(-0.22)$ & $(0.77)$ & $(-0.43)$ & $(-1.71)$ \\
\hline \multirow[t]{2}{*}{ Carhart $\alpha$} & 0.09 & 0.09 & 0.07 & 0.06 & 0.06 & 0.00 & 0.09 & -0.02 & 0.04 & -0.03 & $-0.13 *$ \\
\hline & $(1.26)$ & $(1.65)$ & $(1.17)$ & (1.07) & $(1.15)$ & $(-0.06)$ & (1.63) & $(-0.3)$ & $(0.59)$ & $(-0.43)$ & $(-1.89)$ \\
\hline \multirow[t]{2}{*}{$\operatorname{PS} \alpha$} & 0.06 & 0.07 & 0.05 & 0.03 & 0.04 & -0.02 & 0.08 & -0.03 & 0.03 & -0.06 & $-0.11^{*}$ \\
\hline & $(0.79)$ & $(1.25)$ & $(0.86)$ & $(0.66)$ & $(0.84)$ & $(-0.38)$ & $(1.36)$ & $(-0.54)$ & $(0.55)$ & $(-0.75)$ & $(-1.75)$ \\
\hline
\end{tabular}




\section{Table IA.X}

\section{Fund Herding as the Tendency to Follow Longer-Horizon Institutional Trades}

This table presents the performance of decile portfolios formed on the basis of $F H$, the average tendency of mutual funds to follow past institutional trades. FH is constructed from the slope coefficient of cross-sectional regressions of mutual fund trades on past aggregate institutional trades measured over various horizons, controlling for past stock returns, firm size, and book-to-market. Panels A and B use aggregate institutional trades measured in the past two and four quarters, respectively. Panel C uses the persistence in past institutional trades as defined in Dasgupta, Prat, and Verardo (2011). The return series span January 1990 to December 2009 . Decile 10 is the portfolio of funds with the highest fund herding measure. We compute monthly equally-weighted net and gross (net plus expense ratio) returns on the portfolios, as well as riskadjusted returns based on the CAPM, the Fama and French (1993, FF) three-factor model, the Carhart (1997) four-factor model, and the Pastor and Stambaugh (2003, PS) five-factor model. Average returns and alphas are in monthly percentages. Newey-West (1987) $t$-statistics are shown in parentheses. ***, **, and * denote statistical significance at the $1 \%, 5 \%$, and $10 \%$ level, respectively, for the return differentials between deciles 10 and 1 . 


\begin{tabular}{|c|c|c|c|c|c|c|c|c|c|c|c|}
\hline \multicolumn{12}{|c|}{ Panel A: Following Institutional Trades from the Previous Two Quarters } \\
\hline FH rank & 1 & 2 & 3 & 4 & 5 & 6 & 7 & 8 & 9 & 10 & D10-D1 \\
\hline \multicolumn{12}{|c|}{ Net Return } \\
\hline Average & $\begin{array}{c}0.85 \\
(2.94)\end{array}$ & $\begin{array}{c}0.78 \\
(2.74)\end{array}$ & $\begin{array}{c}0.83 \\
(2.90)\end{array}$ & $\begin{array}{c}0.72 \\
(2.48)\end{array}$ & $\begin{array}{c}0.77 \\
(2.68)\end{array}$ & $\begin{array}{c}0.81 \\
(2.76)\end{array}$ & $\begin{array}{c}0.73 \\
(2.48)\end{array}$ & $\begin{array}{c}0.69 \\
(2.35)\end{array}$ & $\begin{array}{c}0.74 \\
(2.47)\end{array}$ & $\begin{array}{c}0.69 \\
(2.29)\end{array}$ & $\begin{array}{c}-0.16^{* * *} \\
(-2.64)\end{array}$ \\
\hline $\mathrm{CAPM} \alpha$ & $\begin{array}{c}0.09 \\
(1.20)\end{array}$ & $\begin{array}{c}0.02 \\
(0.34)\end{array}$ & $\begin{array}{c}0.07 \\
(1.06)\end{array}$ & $\begin{array}{c}-0.05 \\
(-0.71)\end{array}$ & $\begin{array}{c}0.01 \\
(0.15)\end{array}$ & $\begin{array}{c}0.04 \\
(0.64)\end{array}$ & $\begin{array}{l}-0.04 \\
(-0.8)\end{array}$ & $\begin{array}{c}-0.08 \\
(-1.49)\end{array}$ & $\begin{array}{c}-0.04 \\
(-0.74)\end{array}$ & $\begin{array}{c}-0.09 \\
(-1.57)\end{array}$ & $\begin{array}{c}-0.18^{* * *} \\
(-3.02)\end{array}$ \\
\hline FF $\alpha$ & $\begin{array}{c}0.02 \\
(0.30)\end{array}$ & $\begin{array}{l}-0.05 \\
(-0.94)\end{array}$ & $\begin{array}{c}0.00 \\
(-0.09)\end{array}$ & $\begin{array}{l}-0.11 \\
(-2.15)\end{array}$ & $\begin{array}{l}-0.05 \\
(-1.08)\end{array}$ & $\begin{array}{c}0.00 \\
(-0.01)\end{array}$ & $\begin{array}{l}-0.08 \\
(-1.72)\end{array}$ & $\begin{array}{l}-0.11 \\
(-2.41)\end{array}$ & $\begin{array}{l}-0.05 \\
(-1.09)\end{array}$ & $\begin{array}{l}-0.11 \\
(-1.96)\end{array}$ & $\begin{array}{c}-0.13^{* *} \\
(-2.35)\end{array}$ \\
\hline Carhart $\alpha$ & $\begin{array}{c}0.03 \\
(0.43)\end{array}$ & $\begin{array}{c}-0.03 \\
(-0.53)\end{array}$ & $\begin{array}{c}0.00 \\
(0.03)\end{array}$ & $\begin{array}{l}-0.10 \\
(-1.92)\end{array}$ & $\begin{array}{l}-0.05 \\
(-1.01)\end{array}$ & $\begin{array}{c}0.00 \\
(0.10)\end{array}$ & $\begin{array}{l}-0.08 \\
(-1.64)\end{array}$ & $\begin{array}{c}-0.11 \\
(-2.07)\end{array}$ & $\begin{array}{l}-0.06 \\
(-1.2)\end{array}$ & $\begin{array}{c}-0.12 \\
(-2.00)\end{array}$ & $\begin{array}{c}-0.15 * * * \\
(-2.64)\end{array}$ \\
\hline PS $\alpha$ & $\begin{array}{c}0.00 \\
(-0.04)\end{array}$ & $\begin{array}{c}-0.05 \\
(-0.89)\end{array}$ & $\begin{array}{l}-0.02 \\
(-0.31)\end{array}$ & $\begin{array}{c}-0.12 \\
(-2.32)\end{array}$ & $\begin{array}{l}-0.07 \\
(-1.39)\end{array}$ & $\begin{array}{l}-0.01 \\
(-0.1)\end{array}$ & $\begin{array}{l}-0.09 \\
(-1.78)\end{array}$ & $\begin{array}{c}-0.12 \\
(-2.27)\end{array}$ & $\begin{array}{l}-0.07 \\
(-1.31)\end{array}$ & $\begin{array}{c}-0.13 \\
(-2.14)\end{array}$ & $\begin{array}{c}-0.13^{* *} \\
(-2.29)\end{array}$ \\
\hline \multicolumn{12}{|c|}{ Gross Return } \\
\hline Average & $\begin{array}{c}0.96 \\
(3.33)\end{array}$ & $\begin{array}{c}0.88 \\
(3.12)\end{array}$ & $\begin{array}{c}0.93 \\
(3.26)\end{array}$ & $\begin{array}{c}0.82 \\
(2.82)\end{array}$ & $\begin{array}{c}0.87 \\
(3.02)\end{array}$ & $\begin{array}{c}0.91 \\
(3.10)\end{array}$ & $\begin{array}{c}0.83 \\
(2.82)\end{array}$ & $\begin{array}{c}0.79 \\
(2.69)\end{array}$ & $\begin{array}{c}0.84 \\
(2.81)\end{array}$ & $\begin{array}{c}0.80 \\
(2.65)\end{array}$ & $\begin{array}{c}-0.16^{* * *} \\
(-2.70)\end{array}$ \\
\hline $\mathrm{CAPM} \alpha$ & $\begin{array}{c}0.20 \\
(2.73)\end{array}$ & $\begin{array}{c}0.13 \\
(1.88)\end{array}$ & $\begin{array}{c}0.17 \\
(2.61)\end{array}$ & $\begin{array}{c}0.05 \\
(0.82)\end{array}$ & $\begin{array}{c}0.11 \\
(1.88)\end{array}$ & $\begin{array}{c}0.14 \\
(2.38)\end{array}$ & $\begin{array}{c}0.06 \\
(0.99)\end{array}$ & $\begin{array}{c}0.02 \\
(0.32)\end{array}$ & $\begin{array}{c}0.06 \\
(1.07)\end{array}$ & $\begin{array}{c}0.02 \\
(0.26)\end{array}$ & $\begin{array}{c}-0.19 * * * \\
(-3.08)\end{array}$ \\
\hline FF $\alpha$ & $\begin{array}{c}0.13 \\
(2.26)\end{array}$ & $\begin{array}{c}0.05 \\
(0.99)\end{array}$ & $\begin{array}{c}0.10 \\
(1.82)\end{array}$ & $\begin{array}{c}-0.01 \\
(-0.24)\end{array}$ & $\begin{array}{c}0.05 \\
(1.03)\end{array}$ & $\begin{array}{c}0.10 \\
(2.08)\end{array}$ & $\begin{array}{c}0.02 \\
(0.43)\end{array}$ & $\begin{array}{c}-0.01 \\
(-0.29)\end{array}$ & $\begin{array}{c}0.05 \\
(1.00)\end{array}$ & $\begin{array}{c}0.00 \\
(0.01)\end{array}$ & $\begin{array}{c}-0.13 * * \\
(-2.42)\end{array}$ \\
\hline Carhart $\alpha$ & $\begin{array}{c}0.14 \\
(2.31)\end{array}$ & $\begin{array}{c}0.08 \\
(1.32)\end{array}$ & $\begin{array}{c}0.10 \\
(1.82)\end{array}$ & $\begin{array}{c}0.00 \\
(-0.06)\end{array}$ & $\begin{array}{c}0.05 \\
(1.01)\end{array}$ & $\begin{array}{c}0.10 \\
(2.07)\end{array}$ & $\begin{array}{c}0.02 \\
(0.35)\end{array}$ & $\begin{array}{c}-0.01 \\
(-0.13)\end{array}$ & $\begin{array}{c}0.04 \\
(0.76)\end{array}$ & $\begin{array}{c}-0.01 \\
(-0.23)\end{array}$ & $\begin{array}{c}-0.15^{* * *} \\
(-2.70)\end{array}$ \\
\hline PS $\alpha$ & $\begin{array}{c}0.11 \\
(1.92)\end{array}$ & $\begin{array}{c}0.05 \\
(0.94)\end{array}$ & $\begin{array}{c}0.08 \\
(1.50)\end{array}$ & $\begin{array}{c}-0.02 \\
(-0.43)\end{array}$ & $\begin{array}{c}0.03 \\
(0.69)\end{array}$ & $\begin{array}{c}0.09 \\
(1.81)\end{array}$ & $\begin{array}{c}0.01 \\
(0.10)\end{array}$ & $\begin{array}{c}-0.02 \\
(-0.34)\end{array}$ & $\begin{array}{c}0.03 \\
(0.62)\end{array}$ & $\begin{array}{c}-0.02 \\
(-0.37)\end{array}$ & $\begin{array}{c}-0.13 * * \\
(-2.36)\end{array}$ \\
\hline
\end{tabular}




\begin{tabular}{|c|c|c|c|c|c|c|c|c|c|c|c|}
\hline \multicolumn{12}{|c|}{ Panel B: Following Institutional Trades from the Previous Year } \\
\hline FH rank & 1 & 2 & 3 & 4 & 5 & 6 & 7 & 8 & 9 & 10 & D10-D1 \\
\hline \multicolumn{12}{|c|}{ Net Return } \\
\hline \multirow[t]{2}{*}{ Average } & 0.79 & 0.78 & 0.85 & 0.75 & 0.74 & 0.81 & 0.75 & 0.73 & 0.73 & 0.66 & $-0.13 * *$ \\
\hline & $(2.66)$ & $(2.71)$ & $(2.97)$ & $(2.61)$ & $(2.54)$ & $(2.84)$ & $(2.60)$ & $(2.47)$ & $(2.46)$ & $(2.20)$ & $(-2.26)$ \\
\hline \multirow[t]{2}{*}{ CAPM $\alpha$} & 0.02 & 0.02 & 0.09 & -0.01 & -0.03 & 0.05 & -0.01 & -0.05 & -0.05 & -0.12 & $-0.14 * *$ \\
\hline & $(0.24)$ & $(0.30)$ & $(1.49)$ & $(-0.23)$ & $(-0.52)$ & $(0.92)$ & $(-0.25)$ & $(-0.9)$ & $(-0.85)$ & $(-2.02)$ & $(-2.44)$ \\
\hline \multirow[t]{2}{*}{$\mathrm{FF} \alpha$} & -0.05 & -0.04 & 0.03 & -0.07 & -0.08 & 0.01 & -0.06 & -0.08 & -0.08 & -0.14 & $-0.09 *$ \\
\hline & $(-0.78)$ & $(-0.83)$ & $(0.70)$ & $(-1.6)$ & $(-1.71)$ & $(0.13)$ & $(-1.20)$ & $(-1.68)$ & $(-1.56)$ & $(-2.51)$ & $(-1.77)$ \\
\hline \multirow[t]{2}{*}{ Carhart $\alpha$} & -0.05 & -0.03 & 0.02 & -0.08 & -0.07 & 0.00 & -0.05 & -0.07 & -0.06 & -0.14 & -0.09 \\
\hline & $(-0.75)$ & $(-0.63)$ & $(0.47)$ & $(-1.52)$ & $(-1.44)$ & $(-0.03)$ & $(-0.99)$ & $(-1.48)$ & $(-1.24)$ & $(-2.23)$ & $(-1.63)$ \\
\hline \multirow[t]{2}{*}{$\operatorname{PS} \alpha$} & -0.06 & -0.05 & 0.00 & -0.09 & -0.08 & -0.02 & -0.07 & -0.09 & -0.07 & -0.16 & $-0.10^{*}$ \\
\hline & $(-0.86)$ & $(-0.93)$ & $(-0.06)$ & $(-1.85)$ & $(-1.67)$ & $(-0.38)$ & $(-1.41)$ & $(-1.73)$ & $(-1.39)$ & $(-2.58)$ & $(-1.77)$ \\
\hline \multicolumn{12}{|c|}{ Gross Return } \\
\hline \multirow[t]{2}{*}{ Average } & 0.90 & 0.88 & 0.95 & 0.84 & 0.84 & 0.91 & 0.85 & 0.83 & 0.84 & 0.77 & $-0.13 * *$ \\
\hline & $(3.03)$ & $(3.08)$ & $(3.31)$ & $(2.96)$ & $(2.88)$ & $(3.18)$ & $(2.95)$ & $(2.80)$ & $(2.80)$ & $(2.55)$ & $(-2.34)$ \\
\hline \multirow[t]{2}{*}{ CAPM $\alpha$} & 0.13 & 0.12 & 0.19 & 0.08 & 0.07 & 0.15 & 0.09 & 0.05 & 0.05 & -0.02 & $-0.15 * *$ \\
\hline & (1.63) & (1.94) & (3.12) & $(1.42)$ & (1.19) & (2.69) & $(1.58)$ & $(0.92)$ & $(0.97)$ & $(-0.25)$ & $(-2.52)$ \\
\hline \multirow[t]{2}{*}{$\mathrm{FF} \alpha$} & 0.06 & 0.06 & 0.13 & 0.02 & 0.02 & 0.10 & 0.04 & 0.02 & 0.03 & -0.03 & $-0.09 *$ \\
\hline & $(0.93)$ & $(1.21)$ & $(2.71)$ & $(0.54)$ & $(0.40)$ & $(2.27)$ & $(0.81)$ & $(0.43)$ & $(0.55)$ & $(-0.6)$ & $(-1.86)$ \\
\hline \multirow[t]{2}{*}{ Carhart $\alpha$} & 0.06 & 0.07 & 0.12 & 0.02 & 0.03 & 0.10 & 0.04 & 0.03 & 0.04 & -0.03 & $-0.09^{*}$ \\
\hline & $(0.87)$ & $(1.29)$ & $(2.37)$ & $(0.43)$ & $(0.67)$ & $(1.96)$ & $(0.82)$ & $(0.53)$ & $(0.74)$ & $(-0.52)$ & $(-1.72)$ \\
\hline \multirow[t]{2}{*}{$\operatorname{PS} \alpha$} & 0.05 & 0.05 & 0.10 & 0.00 & 0.02 & 0.08 & 0.02 & 0.01 & 0.03 & -0.05 & $-0.10^{*}$ \\
\hline & $(0.74)$ & $(1.00)$ & (1.94) & $(0.07)$ & $(0.36)$ & $(1.57)$ & $(0.45)$ & $(0.23)$ & $(0.59)$ & $(-0.82)$ & $(-1.86)$ \\
\hline
\end{tabular}




\begin{tabular}{|c|c|c|c|c|c|c|c|c|c|c|c|}
\hline \multicolumn{12}{|c|}{ Panel C: Following Persistent Past Institutional Trades } \\
\hline FH rank & 1 & 2 & 3 & 4 & 5 & 6 & 7 & 8 & 9 & 10 & D10-D1 \\
\hline \multicolumn{12}{|c|}{ Net Return } \\
\hline Average & $(2.85)$ & $(2.61)$ & $(2.59)$ & $(2.65)$ & $(2.70)$ & $(2.70)$ & $(2.76)$ & $(2.56)$ & $(2.41)$ & $(2.25)$ & $(-2.81)$ \\
\hline \multirow[t]{2}{*}{$\mathrm{CAPM} \alpha$} & 0.06 & -0.01 & -0.02 & -0.01 & 0.01 & 0.02 & 0.04 & -0.02 & -0.06 & -0.11 & $-0.17 * * *$ \\
\hline & $(0.92)$ & $(-0.16)$ & $(-0.29)$ & $(-0.1)$ & $(0.27)$ & $(0.31)$ & $(0.58)$ & $(-0.33)$ & $(-1.01)$ & $(-1.7)$ & $(-3.36)$ \\
\hline $\mathrm{FF} \alpha$ & $(0.12)$ & $(-1.44)$ & $(-1.52)$ & $(-1.21)$ & $(-0.73)$ & $(-0.78)$ & $(-0.09)$ & $(-1.26)$ & $(-1.61)$ & $(-2.32)$ & $(-2.88)$ \\
\hline \multirow[t]{2}{*}{ Carhart $\alpha$} & 0.01 & -0.07 & -0.07 & -0.05 & -0.04 & -0.03 & -0.01 & -0.06 & -0.08 & -0.13 & $-0.14 * * *$ \\
\hline & $(0.14)$ & $(-1.32)$ & $(-1.17)$ & $(-0.92)$ & $(-0.73)$ & $(-0.67)$ & $(-0.14)$ & $(-1.25)$ & $(-1.52)$ & $(-2.23)$ & $(-3.02)$ \\
\hline \multirow[t]{2}{*}{$\operatorname{PS} \alpha$} & -0.01 & -0.10 & -0.09 & -0.07 & -0.05 & -0.05 & -0.01 & -0.07 & -0.09 & -0.15 & $-0.13 * * *$ \\
\hline & $(-0.23)$ & $(-1.99)$ & $(-1.63)$ & $(-1.23)$ & $(-1.11)$ & $(-0.95)$ & $(-0.25)$ & $(-1.35)$ & $(-1.7)$ & $(-2.49)$ & $(-2.78)$ \\
\hline \multicolumn{12}{|c|}{ Gross Return } \\
\hline Average & 0.93 & 0.86 & 0.84 & 0.85 & 0.88 & 0.89 & 0.90 & 0.86 & 0.83 & 0.79 & $-0.15 * * *$ \\
\hline \multirow[t]{2}{*}{ CAPM $\alpha$} & 0.17 & 0.09 & 0.08 & 0.09 & 0.11 & 0.12 & 0.13 & 0.08 & 0.04 & 0.00 & $-0.17 * * *$ \\
\hline & $(2.63)$ & $(1.50)$ & $(1.31)$ & $(1.58)$ & $(2.05)$ & $(1.98)$ & $(2.19)$ & $(1.38)$ & $(0.74)$ & $(0.05)$ & $(-3.41)$ \\
\hline \multirow[t]{2}{*}{ FF $\alpha$} & 0.12 & 0.03 & 0.02 & 0.04 & 0.06 & 0.06 & 0.09 & 0.04 & 0.02 & -0.02 & $-0.14 * * *$ \\
\hline & $(2.13)$ & $(0.66)$ & $(0.33)$ & $(0.78)$ & $(1.39)$ & $(1.36)$ & $(1.81)$ & $(0.86)$ & $(0.37)$ & $(-0.37)$ & $(-2.92)$ \\
\hline \multirow[t]{2}{*}{ Carhart $\alpha$} & 0.12 & 0.03 & 0.03 & 0.05 & 0.06 & 0.07 & 0.09 & 0.04 & 0.02 & -0.03 & $-0.14 * * *$ \\
\hline & $(2.02)$ & $(0.63)$ & $(0.63)$ & $(0.95)$ & $(1.24)$ & $(1.35)$ & $(1.64)$ & $(0.73)$ & $(0.40)$ & $(-0.42)$ & $(-3.07)$ \\
\hline \multirow[t]{2}{*}{$\operatorname{PS} \alpha$} & 0.10 & 0.00 & 0.01 & 0.03 & 0.04 & 0.05 & 0.08 & 0.03 & 0.01 & -0.04 & $-0.14 * * *$ \\
\hline & (1.67) & $(0.06)$ & $(0.24)$ & $(0.61)$ & $(0.89)$ & $(1.02)$ & $(1.47)$ & $(0.55)$ & $(0.19)$ & $(-0.65)$ & $(-2.82)$ \\
\hline
\end{tabular}


Table IA.XI

Fund Herding Measured by the Equally Weighted Average of Quarterly Betas

This table presents the performance of decile portfolios formed on the basis of FH, the average tendency of mutual funds to follow past institutional trades. FH is constructed from the slope coefficient of cross-sectional regressions of mutual fund trades on past aggregate institutional trades measured in the previous quarter, controlling for past stock returns, firm size, and the book-to-market ratio. The quarterly slope coefficients are equally weighted over the lifetime of a fund. The return series span January 1990 to December 2009. Decile 10 is the portfolio of funds with the highest fund herding measure. We compute monthly equally weighted net and gross (net plus expense ratio) returns on the portfolios, as well as risk-adjusted returns based on the CAPM, the Fama and French (1993, FF) three-factor model, the Carhart (1997) four-factor model, and the Pastor and Stambaugh (2003, PS) five-factor model. Average returns and alphas are in monthly percentages. Newey-West (1987) $t$-statistics are shown in parentheses. $* * *, * *$, and $*$ denote statistical significance at the $1 \%, 5 \%$, and $10 \%$ level, respectively, for the return differentials between deciles 10 and 1 .

\begin{tabular}{|c|c|c|c|c|c|c|c|c|c|c|c|}
\hline FH rank & 1 & 2 & 3 & 4 & 5 & 6 & 7 & 8 & 9 & 10 & D10-D1 \\
\hline \multicolumn{12}{|c|}{ Net Return } \\
\hline \multirow[t]{2}{*}{ Average } & 0.88 & 0.89 & 0.90 & 0.84 & 0.84 & 0.89 & 0.88 & 0.83 & 0.84 & 0.76 & $-0.12 * * *$ \\
\hline & $(3.46)$ & $(3.49)$ & $(3.53)$ & $(3.21)$ & (3.17) & (3.4) & $(3.37)$ & $(3.17)$ & $(3.15)$ & $(2.86)$ & $(-2.67)$ \\
\hline \multirow[t]{2}{*}{$\mathrm{CAPM} \alpha$} & -0.01 & -0.00 & 0.01 & -0.07 & -0.08 & -0.02 & -0.03 & -0.08 & -0.08 & -0.16 & $-0.15 * * *$ \\
\hline & $(-0.19)$ & $(-0.09)$ & $(0.12)$ & $(-1.37)$ & $(-1.51)$ & $(-0.44)$ & $(-0.63)$ & $(-1.85)$ & $(-1.71)$ & $(-3.42)$ & $(-3.29)$ \\
\hline \multirow[t]{2}{*}{$\mathrm{FF} \alpha$} & -0.05 & -0.05 & -0.04 & -0.09 & -0.09 & -0.01 & -0.01 & -0.06 & -0.06 & -0.15 & $-0.10 * *$ \\
\hline & $(-1.09)$ & $(-1.17)$ & $(-0.94)$ & $(-2.27)$ & $(-2.27)$ & $(-0.31)$ & $(-0.24)$ & $(-1.62)$ & $(-1.45)$ & $(-3.64)$ & $(-2.57)$ \\
\hline \multirow[t]{2}{*}{ Carhart $\alpha$} & -0.04 & -0.05 & -0.03 & -0.10 & -0.10 & -0.03 & -0.01 & -0.06 & -0.05 & -0.15 & $-0.11 * *$ \\
\hline & $(-0.77)$ & $(-1.05)$ & $(-0.69)$ & $(-2.42)$ & $(-2.5)$ & $(-0.62)$ & $(-0.34)$ & $(-1.56)$ & $(-1.23)$ & $(-3.28)$ & $(-2.53)$ \\
\hline \multirow[t]{2}{*}{$\operatorname{PS} \alpha$} & -0.05 & -0.05 & -0.03 & -0.10 & -0.09 & -0.02 & -0.01 & -0.06 & -0.04 & -0.13 & $-0.09 * *$ \\
\hline & $(-0.93)$ & $(-1.09)$ & $(-0.72)$ & $(-2.27)$ & $(-2.16)$ & $(-0.39)$ & $(-0.18)$ & $(-1.33)$ & $(-0.97)$ & $(-2.88)$ & $(-2.00)$ \\
\hline \multicolumn{12}{|c|}{ Gross Return } \\
\hline \multirow[t]{2}{*}{ Average } & 0.99 & 0.99 & 1.00 & 0.93 & 0.93 & 0.98 & 0.98 & 0.92 & 0.94 & 0.86 & $-0.13 * * *$ \\
\hline & (3.89) & $(3.88)$ & (3.92) & $(3.57)$ & $(3.52)$ & $(3.76)$ & $(3.73)$ & $(3.53)$ & $(3.51)$ & $(3.25)$ & $(-2.77)$ \\
\hline $\mathrm{CAPM} \alpha$ & (1.7) & (1.8) & $(2.14)$ & $(0.5)$ & $(0.35)$ & $(1.55)$ & (1.49) & $(0.28)$ & $(0.35)$ & $(-1.2)$ & $(-3.39)$ \\
\hline \multirow[t]{2}{*}{$\mathrm{FF} \alpha$} & 0.06 & 0.05 & 0.06 & 0.00 & 0.01 & 0.08 & 0.08 & 0.03 & 0.04 & -0.05 & $-0.11 * * *$ \\
\hline & (1.3) & $(1.25)$ & $(1.55)$ & $(0.06)$ & $(0.19)$ & (1.95) & $(2.22)$ & $(0.78)$ & $(0.88)$ & $(-1.16)$ & $(-2.67)$ \\
\hline \multirow[t]{2}{*}{ Carhart $\alpha$} & 0.07 & 0.05 & 0.07 & -0.01 & -0.01 & 0.07 & 0.08 & 0.03 & 0.04 & -0.04 & $-0.11 * * *$ \\
\hline & (1.46) & $(1.23)$ & (1.63) & $(-0.16)$ & $(-0.18)$ & $(1.49)$ & $(1.85)$ & $(0.75)$ & $(0.98)$ & $(-0.98)$ & $(-2.63)$ \\
\hline \multirow[t]{2}{*}{ PS $\alpha$} & 0.06 & 0.05 & 0.07 & -0.00 & 0.00 & 0.08 & 0.08 & 0.04 & 0.05 & -0.03 & $-0.09 * *$ \\
\hline & $(1.28)$ & $(1.19)$ & $(1.55)$ & $(-0.08)$ & $(0.1)$ & $(1.64)$ & $(1.96)$ & $(0.94)$ & $(1.22)$ & $(-0.6)$ & $(-2.10)$ \\
\hline
\end{tabular}




\section{Table IA.XII}

\section{Fund Herding Measured by Quarterly Betas}

This table presents the performance of decile portfolios formed on the basis of $F H$, the average tendency of mutual funds to follow past institutional trades. FH is constructed as the slope coefficient of cross-sectional regressions of mutual fund trades on past aggregate institutional trades measured in the previous quarter, controlling for past stock returns, firm size, and the book-to-market ratio. The return series span January 1990 to December 2009 . Decile 10 is the portfolio of funds with the highest fund herding measure. We compute monthly equally weighted net and gross (net plus expense ratio) returns on the portfolios, as well as risk-adjusted returns based on the CAPM, the Fama and French (1993, FF) three-factor model, the Carhart (1997) four-factor model, and the Pastor and Stambaugh (2003, PS) five-factor model. Average returns and alphas are in monthly percentages. Newey-West (1987) $t$-statistics are shown in parentheses. $* * *, * *$, and $*$ denote statistical significance at the $1 \%, 5 \%$, and $10 \%$ level, respectively, for the return differentials between deciles 10 and 1

\begin{tabular}{|c|c|c|c|c|c|c|c|c|c|c|c|}
\hline FH rank & 1 & 2 & 3 & 4 & 5 & 6 & 7 & 8 & 9 & 10 & D10-D1 \\
\hline \multicolumn{12}{|c|}{ Net Return } \\
\hline \multirow[t]{2}{*}{ Average } & 0.64 & 0.63 & 0.64 & 0.64 & 0.61 & 0.61 & 0.63 & 0.60 & 0.63 & 0.55 & $-0.08 * *$ \\
\hline & $(2.16)$ & $(2.11)$ & $(2.15)$ & $(2.18)$ & (2.09) & $(2.07)$ & $(2.10)$ & (1.98) & $(2.06)$ & (1.84) & $(-2.30)$ \\
\hline \multirow[t]{2}{*}{ CAPM $\alpha$} & 0.00 & -0.01 & 0.00 & 0.00 & -0.03 & -0.03 & -0.02 & -0.05 & -0.02 & -0.10 & $-0.09 * *$ \\
\hline & $(-0.06)$ & $(-0.19)$ & $(-0.02)$ & $(-0.01)$ & $(-0.38)$ & $(-0.45)$ & $(-0.24)$ & $(-0.86)$ & $(-0.39)$ & $(-1.78)$ & $(-2.55)$ \\
\hline FF $\alpha$ & -0.03 & -0.06 & -0.06 & -0.05 & -0.08 & -0.08 & -0.07 & -0.08 & -0.04 & -0.11 & $-0.07 * *$ \\
\hline \multirow[t]{2}{*}{ Carhart $\alpha$} & -0.05 & -0.07 & -0.05 & -0.05 & -0.07 & -0.08 & -0.06 & -0.10 & -0.06 & -0.12 & $-0.07 * *$ \\
\hline & $(-1.01)$ & $(-1.31)$ & $(-0.85)$ & $(-0.92)$ & $(-1.2)$ & $(-1.5)$ & $(-1.12)$ & $(-2.01)$ & $(-1.32)$ & $(-2.41)$ & $(-2.13)$ \\
\hline \multirow[t]{2}{*}{$\operatorname{PS} \alpha$} & -0.06 & -0.08 & -0.06 & -0.07 & -0.08 & -0.09 & -0.07 & -0.11 & -0.07 & -0.14 & $-0.07 * *$ \\
\hline & $(-1.26)$ & $(-1.51)$ & $(-1.14)$ & $(-1.17)$ & $(-1.41)$ & $(-1.7)$ & $(-1.25)$ & $(-2.07)$ & $(-1.36)$ & $(-2.54)$ & $(-2.09)$ \\
\hline \multicolumn{12}{|c|}{ Gross Return } \\
\hline \multirow[t]{2}{*}{ Average } & 0.75 & 0.74 & 0.75 & 0.74 & 0.72 & 0.72 & 0.73 & 0.70 & 0.73 & 0.66 & $-0.09 * *$ \\
\hline & $(2.54)$ & $(2.48)$ & $(2.50)$ & $(2.53)$ & $(2.44)$ & $(2.42)$ & $(2.45)$ & $(2.32)$ & $(2.41)$ & $(2.21)$ & $(-2.32)$ \\
\hline $\mathrm{CAPM} \alpha$ & (1.79) & (1.38) & $(1.47)$ & (1.58) & (1.19) & $(1.20)$ & $(1.40)$ & $(0.86)$ & $(1.37)$ & $(0.26)$ & $(-2.56)$ \\
\hline \multirow[t]{2}{*}{ FF $\alpha$} & 0.08 & 0.05 & 0.05 & 0.05 & 0.02 & 0.02 & 0.04 & 0.02 & 0.07 & 0.00 & $-0.07 * *$ \\
\hline & $(1.62)$ & $(0.96)$ & $(0.93)$ & $(0.92)$ & $(0.38)$ & $(0.42)$ & $(0.79)$ & $(0.47)$ & $(1.53)$ & $(0.10)$ & $(-2.16)$ \\
\hline \multirow[t]{2}{*}{ Carhart $\alpha$} & 0.06 & 0.04 & 0.06 & 0.05 & 0.04 & 0.03 & 0.05 & 0.00 & 0.04 & -0.02 & $-0.08 * *$ \\
\hline & (1.19) & $(0.73)$ & $(1.00)$ & $(0.94)$ & $(0.63)$ & $(0.52)$ & $(0.87)$ & $(0.07)$ & $(0.87)$ & $(-0.29)$ & $(-2.14)$ \\
\hline \multirow[t]{2}{*}{$\operatorname{PS} \alpha$} & 0.05 & 0.03 & 0.04 & 0.04 & 0.02 & 0.01 & 0.04 & 0.00 & 0.04 & -0.03 & $-0.07 * *$ \\
\hline & $(0.90)$ & $(0.49)$ & $(0.71)$ & $(0.66)$ & $(0.37)$ & $(0.27)$ & $(0.73)$ & $(-0.04)$ & $(0.75)$ & $(-0.5)$ & $(-2.11)$ \\
\hline
\end{tabular}


Table IA.XIII

Fund Herding from Trade Regressions with Nonstandardized Variables

This table presents the performance of decile portfolios formed on the basis of $F H$, the average tendency of mutual funds to follow past institutional trades. FH is constructed from the slope coefficient of cross-sectional regressions of mutual fund trades on past aggregate institutional trades measured in the previous quarter, controlling for past stock returns, firm size, and the book-to-market ratio. The dependent and independent variables are not standardized. The return series span January 1990 to December 2009. Decile 10 is the portfolio of funds with the highest fund herding measure. We compute monthly equally weighted net and gross (net plus expense ratio) returns on the portfolios, as well as risk-adjusted returns based on the CAPM, the Fama and French (1993, FF) three-factor model, the Carhart (1997) four-factor model, and the Pastor and Stambaugh (2003, PS) five-factor model. Average returns and alphas are in monthly percentages. Newey-West (1987) t-statistics are shown in parentheses. $* * *, * *$, and $*$ denote statistical significance at the $1 \%, 5 \%$, and $10 \%$ level, respectively, for the return differentials between deciles 10 and 1 .

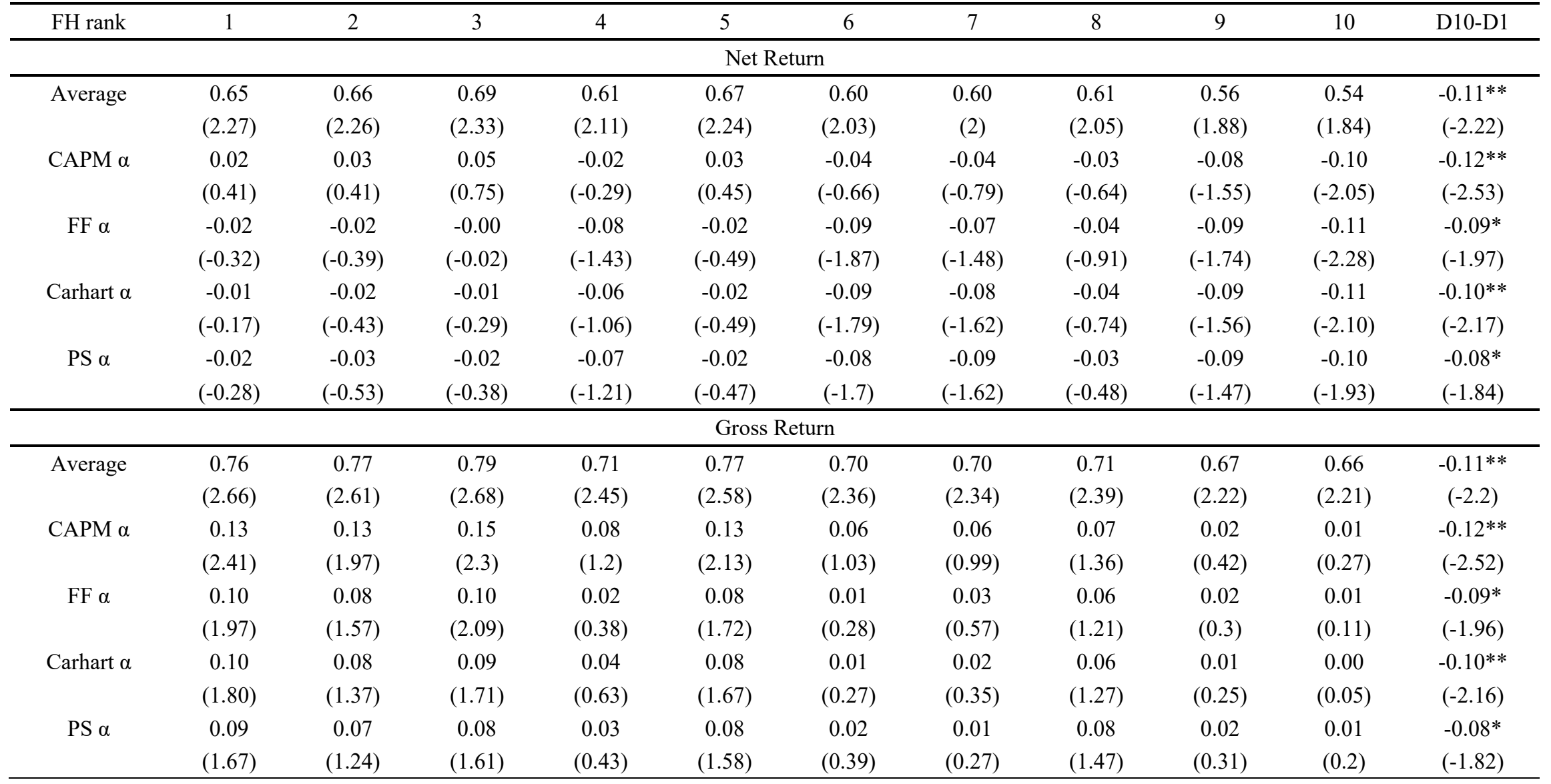


Table IA.XIV

Fund Herding Following Institutional Buys and Sells

This table presents the performance of decile portfolios formed on the basis of $F H$, the average tendency of mutual funds to follow past institutional trades. FH is constructed from the slope coefficient of cross-sectional regressions of mutual fund trades on past aggregate institutional buys (Panel A) and sells (Panel B) measured in the previous quarter, controlling for past stock returns, firm size, and the book-to-market ratio. Decile 10 is the portfolio of funds with the highest FH. We compute monthly equally weighted net and gross (net plus expense ratio) returns, as well as risk-adjusted returns based on the CAPM, the Fama and French (1993, FF) three-factor model, the Carhart (1997) four-factor model, and the Pastor and Stambaugh (2003, PS) five-factor model. Average returns and alphas are in monthly percentages. Newey-West (1987) $t$-statistics are shown in parentheses. $* * *, * *$, and $*$ denote statistical significance at the $1 \%, 5 \%$, and $10 \%$ level, respectively, for the return differentials between deciles 10 and 1.

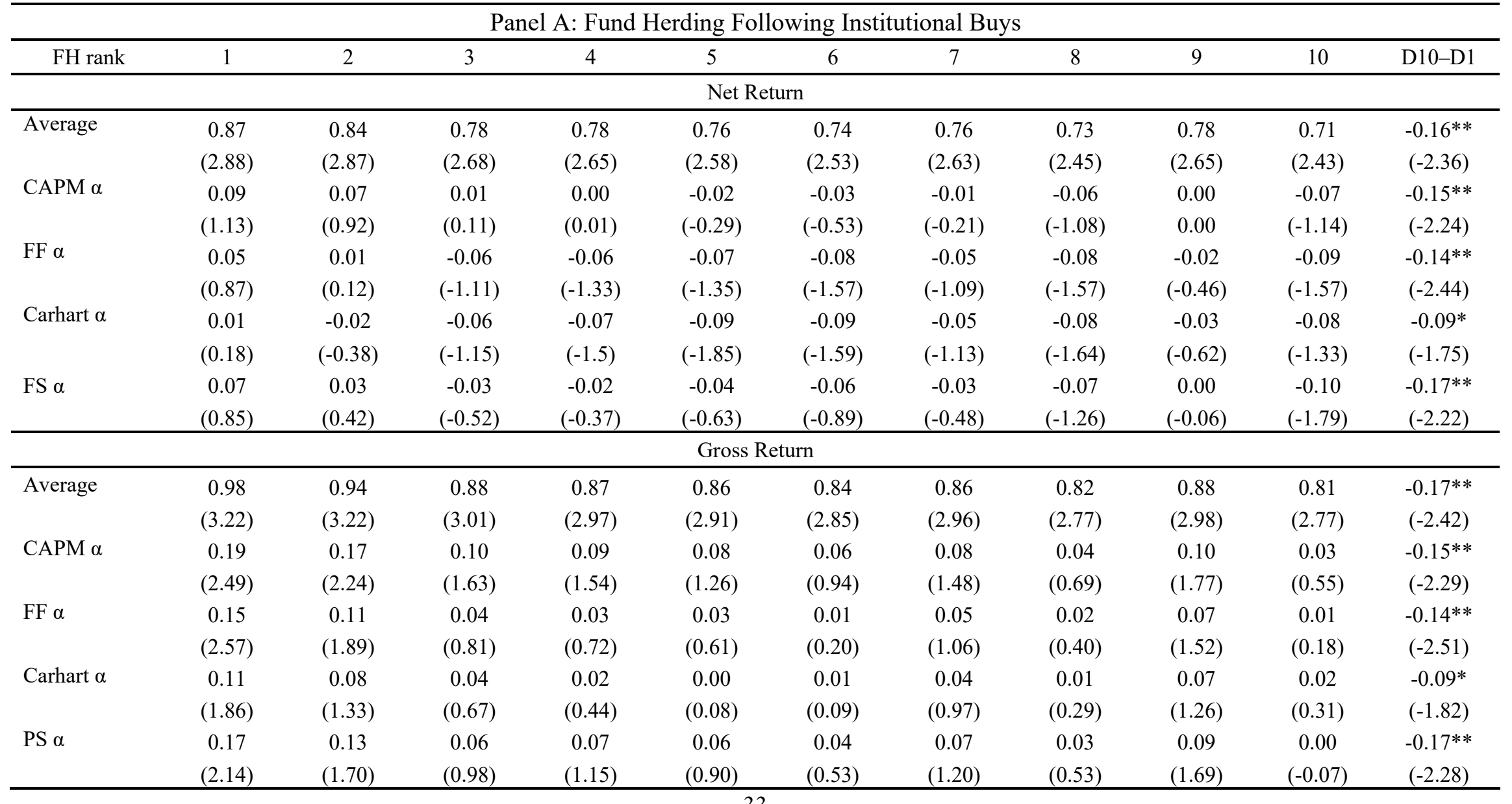




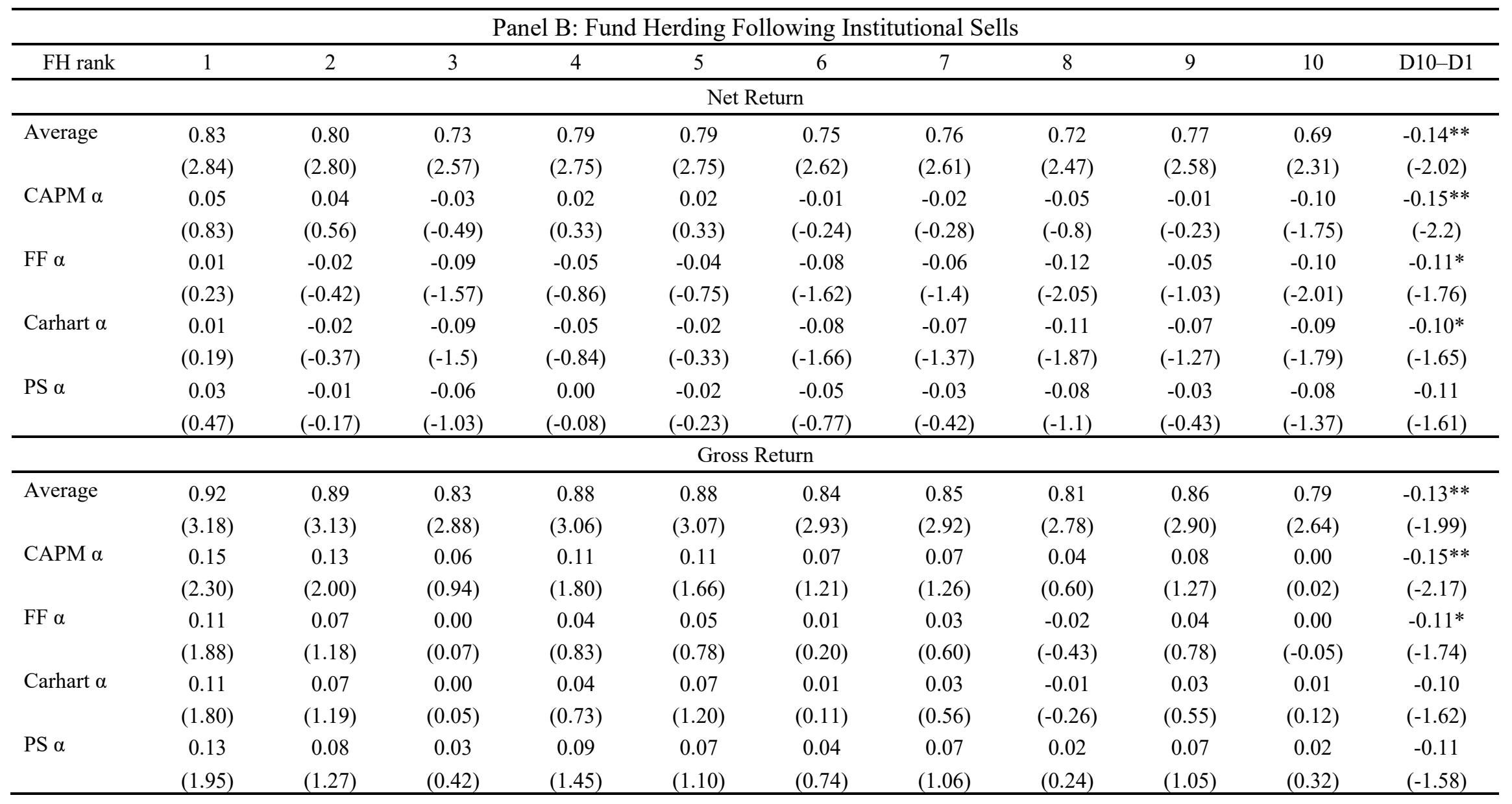




\section{Table IA.XV}

\section{Fund Herding Following Institutional Buys and Sells: Double Sorts}

This table presents the performance of mutual funds sorted on the basis of buy herding (FH/buys) and sell herding (FH/sells). We sort stocks based on the sign of the change in institutional ownership that they experience in the previous quarter, $\Delta \mathrm{IO}$; stocks with positive changes are classified as institutional buys and stocks with negative changes are classified as institutional sells. For these two groups of stocks, we separately estimate the slope coefficient of cross-sectional regressions of mutual fund trades on past institutional trades, controlling for past stock returns, firm size, and book-to-market. We use the estimated betas to create two measures of fund herding (FH) conditional on the sign of aggregate institutional trades: FH/buys and FH/sells. We double-sort funds independently into quartiles based on FH/buys and FH/sells and compute the average monthly performance of the 16 portfolios. The return series span January 1990 to December 2009. We report monthly equally weighted net returns, as well as risk-adjusted returns based on the Carhart (1997) four-factor model. Average returns and alphas are in monthly percentages. Newey-West (1987) $t$-statistics are shown in parentheses. ${ }^{* *}, * *$, and $*$ denote statistical significance at the $1 \%, 5 \%$, and $10 \%$ level, respectively, for the return differentials between portfolios of high and low FH.

\begin{tabular}{|c|c|c|c|c|c|c|c|c|c|c|}
\hline & \multicolumn{5}{|c|}{ Net Return } & \multicolumn{5}{|c|}{ Four-Factor Net $\alpha$} \\
\hline & Low FH/buys & 2 & 3 & High FH/buys & High-Low/buys & Low FH/buys & 2 & 3 & High FH/buys & High-Low/buys \\
\hline \multirow[t]{2}{*}{ Low FH/sells } & 0.80 & 0.74 & 0.76 & 0.66 & $-0.13 * *$ & -0.03 & -0.09 & -0.06 & -0.13 & $-0.10^{*}$ \\
\hline & $(2.76)$ & $(2.50)$ & $(2.59)$ & $(2.33)$ & $(-2.40)$ & $(-0.47)$ & $(-1.42)$ & $(-0.93)$ & $(-1.85)$ & $(-1.82)$ \\
\hline \multirow[t]{2}{*}{2} & 0.82 & 0.80 & 0.77 & 0.76 & -0.06 & 0.00 & -0.03 & -0.04 & -0.02 & -0.02 \\
\hline & $(2.85)$ & $(2.78)$ & $(2.67)$ & $(2.70)$ & $(-0.75)$ & $(0.01)$ & $(-0.6)$ & $(-0.77)$ & $(-0.32)$ & $(-0.27)$ \\
\hline \multirow[t]{2}{*}{3} & 0.82 & 0.83 & 0.77 & 0.69 & $-0.12 * *$ & -0.01 & -0.02 & -0.04 & -0.10 & $-0.10^{*}$ \\
\hline & $(2.83)$ & $(2.83)$ & $(2.63)$ & $(2.38)$ & $(-2.14)$ & $(-0.1)$ & $(-0.31)$ & $(-0.85)$ & $(-1.79)$ & $(-1.78)$ \\
\hline \multirow[t]{2}{*}{ High FH/sells } & 0.72 & 0.72 & 0.76 & 0.66 & -0.06 & -0.08 & -0.11 & -0.08 & -0.10 & -0.02 \\
\hline & $(2.52)$ & $(2.41)$ & $(2.48)$ & $(2.27)$ & $(-1.13)$ & $(-1.3)$ & $(-1.85)$ & $(-1.34)$ & $(-1.41)$ & $(-0.41)$ \\
\hline \multirow[t]{2}{*}{ High-Low/sells } & -0.07 & -0.02 & 0.00 & 0.00 & & -0.04 & -0.02 & -0.02 & 0.03 & \\
\hline & $(-1.37)$ & $(-0.44)$ & $(-0.05)$ & $(0.06)$ & & $(-0.74)$ & $(-0.38)$ & $(-0.43)$ & $(0.62)$ & \\
\hline
\end{tabular}




\section{Table IA.XVI}

\section{Price Pressure from Aggregate Institutional Trades}

This table presents estimates of the relation between aggregate institutional trades and future stock returns. For each month from January 1990 to December 2009 , we regress monthly stock returns in excess of the one-month Treasury bill rate, measured in quarters $t+1$ to $t+4$, on aggregate institutional trades and stock characteristics measured in quarter $t$. Size is the natural log of stock market cap in millions of dollars. BM is the natural log of the book-to-market ratio. MOM3 is the stock return in quarter $t$. MOM12 is the stock return in the previous year. Turnover is trading volume in quarter $t$ divided by the number of shares outstanding. Idiosyncratic volatility is the standard deviation of the residuals from a regression of daily stock returns on the Fama and French (1993) three factors, measured in quarter $t$. Share Issuance is the natural $\log$ of the ratio of the split-adjusted shares outstanding at the end of quarter $t$ divided by the split-adjusted shares outstanding at the end of quarter $t$ - 4 . Analyst earnings forecast revision is the quarterly change in consensus analyst earnings forecasts scaled by the stock price at the end of the previous period. The coefficients reported in the table are time-series averages of monthly regression coefficients, following Fama and MacBeth (1973). Newey-West (1987) $t$-statistics are shown in parentheses. $* * *, * *$, and $*$ denote statistical significance at the $1 \%, 5 \%$, and $10 \%$ level, respectively.

\begin{tabular}{|c|c|c|c|c|c|c|c|c|}
\hline \multirow[t]{2}{*}{ Dep variable: Excess returns (\%) } & \multicolumn{2}{|c|}{ Quarter $t+1$} & \multicolumn{2}{|c|}{ Quarter $t+2$} & \multicolumn{2}{|c|}{ Quarter $t+3$} & \multicolumn{2}{|c|}{ Quarter $t+4$} \\
\hline & 1 & 2 & 1 & 2 & 1 & 2 & 1 & 2 \\
\hline \multirow[t]{2}{*}{$\Delta \mathrm{IO}$} & 0.006 & -0.014 & 0.006 & 0.012 & -0.027 & -0.038 & -0.002 & 0.010 \\
\hline & $(0.24)$ & $(-0.57)$ & $(0.22)$ & $(0.51)$ & $(-0.90)$ & $(-1.44)$ & $(-0.09)$ & $(0.40)$ \\
\hline \multirow[t]{2}{*}{ Size } & 0.027 & $-0.148 * *$ & 0.032 & -0.029 & -0.008 & -0.024 & -0.010 & 0.018 \\
\hline & $(0.28)$ & $(-1.97)$ & $(0.32)$ & $(-0.39)$ & $(-0.08)$ & $(-0.31)$ & $(-0.10)$ & $(0.23)$ \\
\hline \multirow[t]{2}{*}{ BM } & $0.198^{*}$ & 0.082 & $0.211 *$ & 0.124 & 0.137 & 0.078 & 0.162 & 0.123 \\
\hline & $(1.78)$ & $(0.99)$ & $(1.89)$ & $(1.60)$ & $(1.23)$ & $(0.99)$ & $(1.47)$ & $(1.56)$ \\
\hline MOM3 & $(0.06)$ & $(0.03)$ & $(1.84)$ & $(2.47)$ & $(2.06)$ & $(2.66)$ & $(1.30)$ & $(2.14)$ \\
\hline \multirow[t]{2}{*}{ MOM12 } & $0.290 * * *$ & $0.318 * * *$ & -0.003 & 0.033 & $-0.168 * *$ & $-0.117 * *$ & $-0.134 *$ & $-0.116^{*}$ \\
\hline & (3.12) & $(3.90)$ & $(-0.04)$ & $(0.49)$ & $(-2.37)$ & $(-1.96)$ & $(-1.71)$ & $(-1.77)$ \\
\hline \multirow[t]{2}{*}{ Turnover } & & -0.003 & & -0.034 & & -0.014 & & -0.013 \\
\hline & & $(-0.04)$ & & $(-0.43)$ & & $(-0.17)$ & & $(-0.16)$ \\
\hline \multirow[t]{2}{*}{ Idiosyncratic Vol } & & $-0.286^{* * *}$ & & -0.075 & & 0.006 & & 0.116 \\
\hline & & $(-2.67)$ & & $(-0.64)$ & & $(0.05)$ & & $(1.02)$ \\
\hline Share Issuance & & $-0.169 * * *$ & & $-0.178 * * *$ & & $-0.181 * * *$ & & $-0.158 * * *$ \\
\hline \multirow[t]{2}{*}{ Forecast Revision } & & $0.224 * * *$ & & -0.051 & & $0.062 *$ & & 0.029 \\
\hline & & $(5.17)$ & & $(-1.61)$ & & $(1.90)$ & & $(0.80)$ \\
\hline Adj $R^{2}$ & 0.043 & 0.066 & 0.038 & 0.057 & 0.034 & 0.053 & 0.031 & 0.048 \\
\hline
\end{tabular}




\section{Table IA.XVII}

Fund Herding and Future Performance:

\section{Excluding Top and Bottom Deciles of Fund Herding}

This table presents coefficient estimates from predictive panel regressions estimating the association between fund-level herding $(F H)$ and future fund performance. $F H$ is defined as the slope coefficient from cross-sectional regressions of mutual fund trades on past aggregate institutional trades measured in the past quarter, controlling for past stock returns, firm size, and the book-to-market ratio. Future mutual fund performance is measured using Carhart (1997) four-factor alpha (both net and gross in monthly percentages); factor loadings are estimated from rolling-window regressions over the previous three years. The panel regressions control for fund size, age, expense ratio (in percent), turnover, percentage flows in the past quarter, and alpha (in percent) in the past three years. The regressions include time fixed effects and the standard errors are clustered by fund. We exclude from the sample the top $10 \%$ herding funds and the bottom $10 \%$ antiherding funds. The $t$-statistics are presented in parentheses. $* * *, * *$, and $*$ denote statistical significance at the $1 \%, 5 \%$, and $10 \%$ level, respectively.

\begin{tabular}{|c|c|c|c|c|}
\hline & \multicolumn{2}{|c|}{ Four-Factor Net $\alpha$} & \multicolumn{2}{|c|}{ Four-Factor Gross $\alpha$} \\
\hline & $(1)$ & $(2)$ & (3) & $(4)$ \\
\hline \multirow[t]{2}{*}{$F H$} & $-0.424 * * *$ & $-0.487 * * *$ & $-0.421 * * *$ & $-0.485 * * *$ \\
\hline & $(-2.62)$ & $(-2.94)$ & $(-2.60)$ & $(-2.92)$ \\
\hline \multirow[t]{2}{*}{ Size } & & $-0.009 * *$ & & $-0.010 * * *$ \\
\hline & & $(-2.31)$ & & $(-2.68)$ \\
\hline \multirow[t]{2}{*}{ Age } & & $0.018^{*}$ & & $0.018 * *$ \\
\hline & & (1.93) & & $(2.01)$ \\
\hline Expense & & $(-5.12)$ & & $(-1.07)$ \\
\hline \multirow[t]{2}{*}{ Turnover } & & $-0.022 * * *$ & & $-0.022 * * *$ \\
\hline & & $(-3.01)$ & & $(-2.91)$ \\
\hline \multirow[t]{2}{*}{ Flow } & & $0.033^{*}$ & & $0.030^{*}$ \\
\hline & & $(1.77)$ & & $(1.65)$ \\
\hline \multirow[t]{2}{*}{ Alpha } & & 0.005 & & 0.002 \\
\hline & & $(0.20)$ & & $(0.07)$ \\
\hline Adj $R^{2}$ & 0.061 & 0.062 & 0.061 & 0.062 \\
\hline $\mathrm{N}$ & 134,460 & 128,308 & 134,460 & 128,308 \\
\hline
\end{tabular}


Table IA.XVIII

Value-Weighted Fund Portfolios

This table presents the performance of decile portfolios formed on the basis of Fund Herding (FH), the average tendency of mutual funds to follow past institutional trades. FH is constructed from the slope coefficient of cross-sectional regressions of mutual fund trades on past aggregate institutional trades measured in the previous quarter, controlling for past stock returns, firm size, and the book-to-market ratio. The return series span January 1990 to December 2009 . Decile 10 is the portfolio of funds with the highest fund herding measure. We compute monthly value-weighted net and gross (net plus expense ratio) returns on the portfolios, as well as risk-adjusted returns based on the CAPM, the Fama and French (1993, FF) three-factor model, the Carhart (1997) four-factor model, and the Pastor and Stambaugh (2003, PS) five-factor model. Average returns and alphas are in monthly percentages. Newey-West (1987) $t$-statistics are shown in parentheses. ***, **, and $*$ denote statistical significance at the $1 \%, 5 \%$, and $10 \%$ level, respectively, for the return differentials between deciles 10 and 1

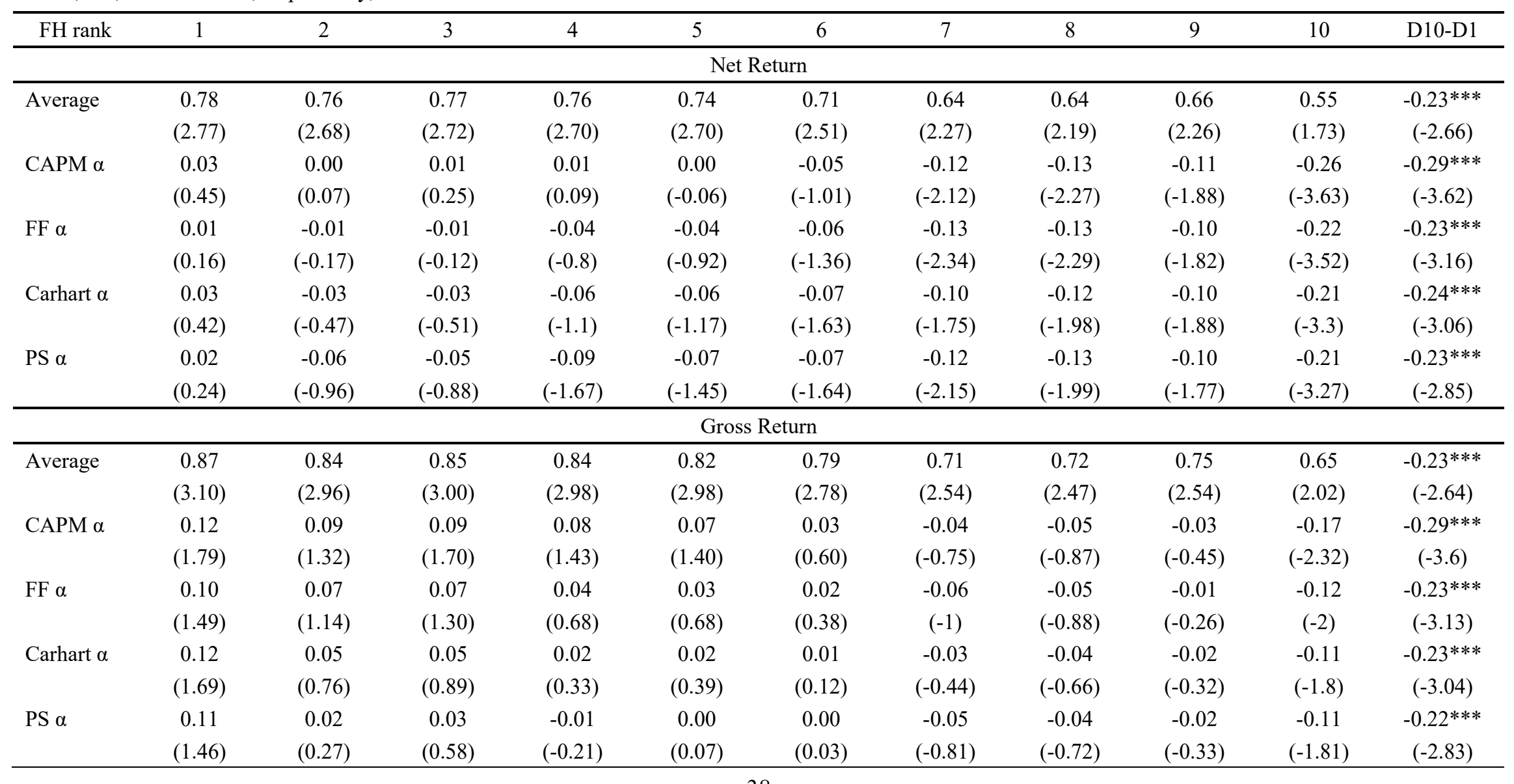


Table IA.XIX

\section{Fund Herding and Stock Characteristics}

This table presents the average characteristics of stock holdings for decile portfolios of mutual funds formed on the basis of FH, the average tendency of mutual funds to follow past institutional trades. FH is constructed from the slope coefficient of cross-sectional regressions of mutual fund trades on past aggregate institutional trades measured in the previous quarter, controlling for past stock returns, firm size, and the book-to-market ratio. The sample period spans January 1990 to December 2009.

Decile 10 is the portfolio of funds with the highest average herding measure. The stocks characteristics include size, book-to-market ratio, returns in the past quarter (Momentum), and the level of aggregate institutional ownership (IO). All characteristics are measured in decile ranks.

\begin{tabular}{llllllllllll}
\hline FH rank & 1 & 2 & 3 & 4 & 5 & 6 & 7 & 8 & 9 & 10 \\
\hline & & & & & & & & & & \\
Size Rank & 9.6 & 9.6 & 9.6 & 9.6 & 9.6 & 9.6 & 9.7 & 9.7 & 9.7 & 9.6 \\
BM Rank & 3.9 & 3.9 & 3.9 & 4.0 & 3.8 & 3.8 & 3.7 & 3.6 & 3.5 & 3.4 \\
Momentum Rank & 6.0 & 6.0 & 6.1 & 6.1 & 6.1 & 6.1 & 6.1 & 6.0 & 6.1 & 6.1 \\
IO Rank & 8.4 & 8.4 & 8.4 & 8.4 & 8.4 & 8.4 & 8.4 & 8.4 & 8.4 & 8.5 \\
\hline
\end{tabular}




\section{Table IA.XX}

\section{Fund Herding and Future Performance: Controlling for $\mathbf{R}^{2}$ from Trade Regressions}

This table presents coefficient estimates from predictive panel regressions estimating the association between fund herding $(F H)$ and future fund performance. $F H$ is constructed from the slope coefficient of cross-sectional regressions of mutual fund trades on past aggregate institutional trades measured in the previous quarter, controlling for past stock returns, firm size, and the book-to-market ratio. Future mutual fund performance is measured using Carhart (1997) four-factor alpha (both net and gross, in monthly percentages); factor loadings are estimated from rolling-window regressions over the previous three years. The panel regressions control for the $\mathrm{R}^{2}$ from the trade regressions used to estimate $F H$. We also control for fund size, age, expense ratio (in percent), turnover, percentage flows in the previous quarter, alpha (in percent) estimated over the previous three years, active share, and similarity with the investment decisions of successful funds. The regressions include time fixed effects and the standard errors are clustered by fund. $t$-statistics are presented in parentheses. $* * *, * *$, and $*$ denote statistical significance at the $1 \%, 5 \%$, and $10 \%$ level, respectively.

\begin{tabular}{|c|c|c|c|c|}
\hline & \multicolumn{2}{|c|}{ Four-Factor Net $\alpha(t+1)$} & \multicolumn{2}{|c|}{ Four-Factor Gross $\alpha(t+1)$} \\
\hline & $(1)$ & (2) & (3) & (4) \\
\hline Fund Herding & $\begin{array}{c}-0.446 * * * \\
(-4.87)\end{array}$ & $\begin{array}{c}-0.512 * * * \\
(-4.31)\end{array}$ & $\begin{array}{c}-0.445^{* * *} \\
(-4.86)\end{array}$ & $\begin{array}{c}-0.508 * * * \\
(-4.27)\end{array}$ \\
\hline Size & $\begin{array}{c}-0.006^{*} \\
(-1.69)\end{array}$ & $\begin{array}{c}-0.008^{*} \\
(-1.77)\end{array}$ & $\begin{array}{c}-0.007 * * \\
(-2.08)\end{array}$ & $\begin{array}{c}-0.009 * * \\
(-2.06)\end{array}$ \\
\hline Age & $\begin{array}{l}0.014 \\
(1.60)\end{array}$ & $\begin{array}{l}-0.005 \\
(-0.48)\end{array}$ & $\begin{array}{c}0.014 * \\
(1.67)\end{array}$ & $\begin{array}{l}-0.004 \\
(-0.43)\end{array}$ \\
\hline Expense & $\begin{array}{c}-0.079 * * * \\
(-4.83)\end{array}$ & $\begin{array}{c}-0.105^{* * *} \\
(-5.05)\end{array}$ & $\begin{array}{l}-0.009 \\
(-0.52)\end{array}$ & $\begin{array}{c}-0.034^{*} \\
(-1.65)\end{array}$ \\
\hline Turnover & $\begin{array}{c}-0.025 * * * \\
(-3.39)\end{array}$ & $\begin{array}{c}-0.039 * * * \\
(-3.78)\end{array}$ & $\begin{array}{c}-0.024 * * * \\
(-3.30)\end{array}$ & $\begin{array}{c}-0.038^{* * *} \\
(-3.69)\end{array}$ \\
\hline Flow & $\begin{array}{c}0.002 * * * \\
(2.63)\end{array}$ & $\begin{array}{l}0.020 \\
(1.42)\end{array}$ & $\begin{array}{c}0.002 * * * \\
(2.79)\end{array}$ & $\begin{array}{l}0.018 \\
(1.24)\end{array}$ \\
\hline Past Alpha & $\begin{array}{l}0.014 \\
(0.62)\end{array}$ & $\begin{array}{l}0.025 \\
(1.00)\end{array}$ & $\begin{array}{l}0.010 \\
(0.46)\end{array}$ & $\begin{array}{l}0.022 \\
(0.88)\end{array}$ \\
\hline $\mathrm{R}^{2}$ & $\begin{array}{l}0.081 \\
(1.41)\end{array}$ & $\begin{array}{l}-0.079 \\
(-1.06)\end{array}$ & $\begin{array}{l}0.083 \\
(1.45)\end{array}$ & $\begin{array}{l}-0.077 \\
(-1.04)\end{array}$ \\
\hline Active Share & & $\begin{array}{c}0.215^{* * *} \\
(4.75)\end{array}$ & & $\begin{array}{c}0.220 * * * \\
(4.86)\end{array}$ \\
\hline Similarity & & $\begin{array}{c}0.071^{*} \\
(1.81)\end{array}$ & & $\begin{array}{c}0.072 * \\
(1.81)\end{array}$ \\
\hline Adj $R^{2}$ & 0.06 & 0.08 & 0.06 & 0.08 \\
\hline $\mathrm{N}$ & 159238 & 92540 & 159238 & 92540 \\
\hline
\end{tabular}

